\title{
IC3D Classification of Corneal Dystrophies-Edition 2
}

\author{
Jayne S. Weiss, MD,* Hans Ulrik Møller, MD, PhD, † Anthony J. Aldave, MD, $\neq$ Berthold Seitz, MD, $\S$ \\ Cecilie Bredrup, MD, PhD, $\mid$ Tero Kivelä, MD, FEBO,\| Francis L. Munier, MD,**

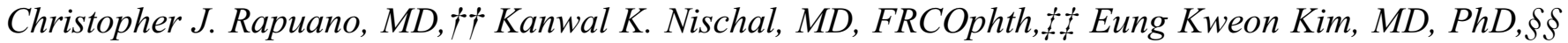 \\ John Sutphin, MD, 99 Massimo Busin, MD,\|\| Antoine Labbé, MD, *** Kenneth R. Kenyon, MD, ††† \\ Shigeru Kinoshita, MD, PhD,tt and Walter Lisch, MD\$\$\$
}

\begin{abstract}
Purpose: To update the 2008 International Classification of Corneal Dystrophies (IC3D) incorporating new clinical, histopathologic, and genetic information.
\end{abstract}

\begin{abstract}
Methods: The IC3D reviewed worldwide peer-reviewed articles for new information on corneal dystrophies published between 2008 and 2014. Using this information, corneal dystrophy templates and anatomic classification were updated. New clinical, histopathologic, and confocal photographs were added.
\end{abstract}

Results: On the basis of revisiting the cellular origin of corneal dystrophy, a modified anatomic classification is proposed consisting of (1) epithelial and subepithelial dystrophies, (2) epithelialstromal TGFBI dystrophies, (3) stromal dystrophies, and (4) endothelial dystrophies. Most of the dystrophy templates are updated. The entity "Epithelial recurrent erosion dystrophies"

Received for publication September 8, 2014; revision received October 2, 2014; accepted October 3, 2014. Published online ahead of print December 14, 2014.

From the *Department of Ophthalmology, Pathology and Pharmacology, Louisiana State University Eye Center of Excellence, Louisiana State University Health Sciences Center, Louisiana State University, New Orleans, LA; $†$ Department of Pediatric Ophthalmology, Viborg Hospital and Aarhus University Hospital, Aarhus, Denmark; \$The Jules Stein Eye Institute, University of California at Los Angeles, Los Angeles, CA; $\S$ Department of Ophthalmology, Saarland University Medical Center, Homburg/Saar, Germany; \Department of Ophthalmology, Haukeland University Hospital, Bergen, Norway; |Department of Opthalmology, Helsinki University Central Hospital, Helsinki, Finland; **Jules-Gonin Eye Hospital, Lausanne, Switzerland; ††Cornea Service, Wills Eye Hospital, Philadelphia, PA; †UUniversity of Pittsburgh Medical Center Children's Eye Center, Pittsburgh, PA; §§Cornea Dystrophy Research Institute, Department of Ophthalmology, College of Medicine, Yonsei University, Seoul, Korea; 9 Department of Ophthalmology, University of Kansas Medical Center, Kansas City, KS; ||||Department of Ophthalmology, Villa Igea Hospital, Maître de Conférences des Universités Praticien Hospitalier, Forli, Italy; ***Centre Hospitalier National d'Ophtalmologie des Quinze-Vingts, Institut de la Vision, Paris, France; ††Tufts University School of Medicine, Harvard Medical School, Schepens Eye Research Institute, New England Eye Center, Boston, MA; + +† Department of Ophthalmology, Kyoto Prefectural University of Medicine, Kyoto, Japan; and $\S \S \S D e p a r t m e n t$ of Ophthalmology, Johannes Gutenberg University Mainz, Mainz, Germany.

Supported by The Cornea Society, Louisiana Lions Eye Foundation, and Research to Prevent Blindness.

The authors have no conflicts of interest to disclose.

Reprints: Jayne S. Weiss, MD, Department of Ophthalmology, Louisiana State University Health Sciences Center, School of Medicine, 2020 Gravier St, Suite B, New Orleans, LA 70112. (e-mail: jweiss@1suhsc.edu).

Copyright (C) 2014 Wolters Kluwer Health, Inc. All rights reserved. actually includes a number of potentially distinct epithelial dystrophies (Franceschetti corneal dystrophy, Dystrophia Smolandiensis, and Dystrophia Helsinglandica) but must be differentiated from dystrophies such as TGFBI-induced dystrophies, which are also often associated with recurrent epithelial erosions. The chromosome locus of Thiel-Behnke corneal dystrophy is only located on $5 \mathrm{q} 31$. The entity previously designated as a variant of Thiel-Behnke corneal dystrophy on chromosome 10q24 may represent a novel corneal dystrophy. Congenital hereditary endothelial dystrophy (CHED, formerly CHED2) is most likely only an autosomal recessive disorder. The so-called autosomal dominant inherited CHED (formerly CHED1) is insufficiently distinct to continue to be considered a unique corneal dystrophy. On review of almost all of the published cases, the description appeared most similar to a type of posterior polymorphous corneal dystrophy linked to the same chromosome 20 locus (PPCD1). Confocal microscopy also has emerged as a helpful tool to reveal in vivo features of several corneal dystrophies that previously required histopathologic examination to definitively diagnose.

Conclusions: This revision of the IC3D classification includes an updated anatomic classification of corneal dystrophies more accurately classifying $T G F B I$ dystrophies that affect multiple layers rather than are confined to one corneal layer. Typical histopathologic and confocal images have been added to the corneal dystrophy templates.

Key Words: cornea, cornea dystrophy, cornea pathology, cornea, genetics, genetic disease, hereditary disease, confocal microscopy, histopathology, epithelium, Bowman membrane, stroma, Descemet membrane, endothelium, TGFBI, epithelial and subepithelial dystrophies, epithelial-stromal $T G F B I$ dystrophies, stromal dystrophies, endothelial dystrophies, keratoconus, epithelial basement membrane dystrophy, epithelial recurrent erosion dystrophies, subepithelial mucinous corneal dystrophy, Meesmann dystrophy, gelatinous drop-like corneal dystrophy, Reis-Bücklers corneal dystrophy, Thiel-Behnke corneal dystrophy, Lisch epithelial corneal dystrophy, lattice corneal dystrophy, granular corneal dystrophy type 1, granular corneal dystrophy type 2, macular corneal dystrophy, Schnyder corneal dystrophy, congenital stromal corneal dystrophy, fleck corneal dystrophy, posterior amorphous corneal dystrophy, central cloudy dystrophy of François, pre-Descemet corneal dystrophy, Fuchs endothelial corneal dystrophy, posteror polymorphous corneal dystrophy, congenital corneal endothelial dystrophy and X-linked endothelial dystrophy, histology, confocal microscopy

(Cornea 2015;34:117-159) 


\section{INTRODUCTION}

\section{Dedication}

We dedicate this work to the memory of Gordon K. Klintworth, MD, $\mathrm{PhD}$, a brilliant ophthalmic pathologist, and a highly esteemed member of the International Committee for Classification of Corneal Dystrophies (IC3D), whose legacy of excellence in corneal research and teaching is legendary.

\section{International Committee for the Classification of Corneal Dystrophies}

In 2008, the first IC3D report sought to develop a "new classification system for corneal dystrophies" through integration of the then current information on phenotype, pathology, and especially genetics. ${ }^{1}$ This project was initially undertaken to correct the shortcomings of the century-old phenotypic method of corneal dystrophy classification.

\section{Cornea Dystrophy: History and Definition}

In 1890 , the term corneal dystrophy was introduced into the literature by Groenouw ${ }^{2}$ and then by Biber. ${ }^{3}$ Groenouw reported 2 patients with "noduli corneae," although he did not distinguish between the one patient having granular corneal dystrophy (GCD) and the other having macular corneal dystrophy (MCD). Subsequently, Biber described a patient with lattice corneal dystrophy (LCD). Thereafter, Fuchs, ${ }^{4}$ Uhthoff, ${ }^{5}$ and Yoshida ${ }^{6}$ continued to use the term "corneal dystrophy."

The general term corneal dystrophy describes an inherited disorder that affects, singly or in combination, cells, tissues, and/or organs. ${ }^{1}$ In ophthalmology, corneal dystrophies have typically referred to a group of inherited disorders that are usually bilateral, symmetric, slowly progressive, and not related to environmental or systemic factors. ${ }^{7}$ There are exceptions to each part of the dystrophy definition. Epithelial basement membrane dystrophy (EBMD) and central cloudy dystrophy of François (CCDF) are likely degenerative rather than hereditary conditions in the majority of patients. Corneal dystrophies can also be clinically unilateral, for example, posterior polymorphous corneal dystrophy (PPCD). Systemic changes are occasionally seen as in Schnyder corneal dystrophy (SCD), where hypercholesterolemia is common.

Another challenge is that it is unclear where to draw the dividing line between hereditary bilateral essentially stationary corneal diseases such as cornea plana (from mutations in keratocan) and the hereditary bilateral diseases called corneal dystrophies. This is underscored by the entity, posterior amorphous corneal dystrophy (PACD) (from deletion of keratocan together with 3 other genes), which is typically minimally progressive and can be associated with iris abnormalities. Consequently, many would agree that the term corneal dystrophy may have more historic than practical meaning. However, we have chosen to follow custom, and in this second edition of IC3D, we have continued to address only entities that have been traditionally included in corneal dystrophies.

\section{8 | www.corneajrnl.com}

\section{Keratoconus-Is It a Corneal Dystrophy?}

Do the corneal ectatic diseases, keratoconus and pellucid marginal degeneration, meet the criteria for inclusion in corneal dystrophies? This is a complex and controversial discussion.

The choice to include keratoconus in a corneal dystrophy classification could be supported by the emerging suggestion of a genetic basis. There is a family history in $10 \%$ of cases, increased prevalence in first-degree relatives of affected individuals, and markedly increased prevalence in trisomy 21 . Keratoconus is likely genetically heterogeneous and may have incomplete penetrance and variable expressivity. ${ }^{8-13}$

However, most cases of keratoconus are sporadic, and in contrast to established corneal dystrophies, potential causative associations such as eye rubbing and atopy are noted. There is still insufficient evidence demonstrating a clear genetic basis in the majority of patients with keratoconus. For this reason, the IC3D continues to support exclusion of corneal ectasias from the corneal dystrophy classification. As interest in molecular etiology of keratoconus continues, we anticipate future new insights into the true genetic basis of this highly prevalent corneal disease.

\section{Shortcomings of the Historic Corneal Dystrophy Classification}

There were numerous flaws in the traditional and most widely used corneal dystrophy classification system. ${ }^{14,15}$ Some of the dystrophies were named before the advent of the slit lamp, whereas most were described before the development of genetic mapping. Introduction of genotyping revolutionized our knowledge base of corneal dystrophies. Genotyping revealed both genotypic heterogeneity, that is, a single dystrophy such as Meesmann corneal dystrophy is associated with different genes (KRT3 and KRT12) and with phenotypic heterogeneity, the TGFBI gene is associated with multiple distinct allelic dystrophy phenotypes, Reis-Bücklers corneal dystrophy (RBCD), Thiel-Behnke corneal dystrophy (TBCD), granular corneal dystrophy type 1 (GCD type 1), granular corneal dystrophy type 2 (GCD type 2 ), and classic lattice corneal dystrophy (LCD). ${ }^{1}$ The IC3D classification system attempts to address these critically important shortcomings.

\section{Dystrophy Versus Degeneration and Other Questions}

As noted previously, a number of entities formerly considered as corneal dystrophies are more likely degenerations rather than inherited diseases. For example, the majority of epithelial basement membrane dystrophy (EBMD) cases have no hereditary basis. Central cloudy dystrophy of François (CCDF), although hereditary in a few families, is phenotypically identical to posterior crocodile shagreen. The only distinction is that CCDF is associated with a family history. There are only a few publications describing an entire family with CCDF. ${ }^{16-18}$ Hence, in descriptions of CCDF patients without a detailed family history, it is impossible to exclude the diagnostic possibility of posterior crocodile shagreen degeneration. ${ }^{19}$

Fuchs endothelial corneal dystrophy (FECD) is a very common corneal dystrophy and has a familial basis. ${ }^{20,21}$ Stage 
1 FECD consists of only cornea guttata without corneal decompensation. Not all patients with stage 1 FECD progress. Are nonprogressive corneal guttae evidence of a corneal degeneration rather than FECD? The answer is not known but has important clinical implications. Often, the patient with cornea guttata is informed of having a diagnosis of FECD. If the individual consults the Internet or other sources, their research will inevitably suggest that FECD is a disease that often progresses to corneal edema, visual loss, and surgical intervention. Thus, a premature diagnosis of FECD in the absence of a family history, genetic evidence, or corneal edema can have important adverse psychological impact on the patient who anticipates future visual loss and need for corneal transplantation surgery.

Other dystrophies were described decades ago with minimal or unclear clinical information and no genetic information. In particular, such dystrophies as GraysonWilbrandt might be variants of other well-known dystrophies or might not even exist.

Misleading dystrophy names have also contributed to misdiagnosis. Among individuals with the disease formerly named Schnyder crystalline corneal dystrophy (SCCD), 50\% actually have visible crystalline deposits. ${ }^{22}$ Correct diagnosis of those affected patients in the absence of crystals often confounded even seasoned clinicians who depended on this flawed assumption coupled with erroneous literature, both supporting the notion that crystals were integral to the diagnosis. $^{23,24}$ Indeed, the compounded errors of SCD were the major impetus to create the IC3D nomenclature revision group in 2005. Because the 2008 IC3D publication observed "once established in textbooks, it is exceedingly difficult to purge incorrect information about rare diseases. Many myths are perpetuated because very few ophthalmologists have seen a substantial number of the unusual corneal dystrophies." Even experienced corneal subspecialists often were unable to correctly diagnose those with acrystalline $\mathrm{SCD}^{24}$ and patients went undiagnosed for decades.

\section{Formation of the IC3D in 2005 Leading to Publication in 2008}

Initially, the first requirement for membership in the IC3D group was extensive firsthand knowledge and experience in examining patients with one or more distinct corneal dystrophies. In this way, each dystrophy could be discussed and analyzed by those who had seen the disease rather than solely being informed by published descriptions, which might be erroneous. The group was to critically assess the published literature to purge errors. The members were also necessarily international to assess geographically distinctive founder effects on globally distinct population. Although SCD was extremely common in central Massachusetts in the United States and the west coast of Finland, GCD type 2 was extremely common in Korea. In some cases, the IC3D was fortunate to include the individual who originally described the dystrophy, as in Lisch epithelial corneal dystrophy (LECD) and X-linked endothelial corneal dystrophy. The second requirement for membership in the IC3D was representation from geneticists and ophthalmic pathologists.
The 2008 IC3D publication contained the traditional anatomic classification that organized dystrophies according to the corneal layer that was chiefly affected. ${ }^{14,15}$ Templates for each dystrophy were created in a standard format to summarize clinical, pathological, and genetic information as well as representative clinical photographs.

An evidence-based category system was suggested by Professor Gordon K. Klintworth, MD, $\mathrm{PhD}$, to indicate the level of evidence supporting existence of a given corneal dystrophy depending on how substantive was the knowledge of its clinical, pathological, and genetic basis. He postulated that existence of a new corneal dystrophy must begin with identification of a clinical phenotype and should progress to characterization of the causative gene mutation.

An example of a monogenic category 1 dystrophy is $\mathrm{SCD}$, which is caused by mutations in 1 gene, UBIAD1. Another category 1 dystrophy PACD is caused by deletion of multiple genes, keratocan (KERA), lumican ( $L U M)$, decorin $(D C N)$, and epiphycan $(E P Y C)$. The genetic basis of other dystrophies, such as some types of FECD, may prove to be complex and involve multiple genes.

These categories were specified as follows:

"Category 1: A well-defined corneal dystrophy in which the gene has been mapped and identified and the specific mutations are known.

Category 2: A well-defined corneal dystrophy that has been mapped to one or more specific chromosomal loci, but the gene(s) remains to be identified.

Category 3: A well-defined corneal dystrophy in which the disorder has not yet been mapped to a chromosomal locus.

Category 4: This category is reserved for a suspected, new, or previously documented corneal dystrophy, although the evidence for it, being a distinct entity is not yet convincing."

We postulated that with increased knowledge about a dystrophy, its category should progress over time from 4 to 3 to 2 to 1 . Suspected dystrophies that remain category 4 because no further information ever becomes available may be eventually removed from the nomenclature. The group did not further specify specific criteria for removal of a category 4 dystrophy.

\section{Corneal Dystrophy Purgatory and the Category 4 Dilemma-When Can a Category 4 Dystrophy Be Eliminated?}

In some cases, additional information might show that a category 4 dystrophy is not an independent entity. One such example is central discoid corneal dystrophy (CDCD) ${ }^{25,26}$ This category 4 dystrophy was phenotypically indistinguishable from acrystalline SCD. When the causative gene for SCD was found to be UBIAD $1,{ }^{27,28}$ genetic testing of CDCD similarly demonstrated mutations in UBIAD1 indicating that CDCD was not a unique dystrophy. CDCD was consequently removed before publishing the first IC3D classification, in which it was reclassified as SCD variant. ${ }^{26}$

Should elimination also be considered for a category 4 corneal dystrophy in which no further information to prove or disprove its unique existence is forthcoming? In such a case, there is no evidence to substantiate or to disprove the 
existence of the dystrophy. We consider this the equivalent of corneal dystrophy "purgatory."

A case in point is Grayson-Wilbrandt, a category 4 dystrophy, which was described in 1 publication in 1966 supported only by artist's renditions of phenotype, without clinical photographs or genotyping. ${ }^{29}$ Over the ensuing 4 decades, while no subsequent articles have disputed the original publication, there also have been no articles substantiating these findings. Most members of the IC3D agreed that this entity should be eliminated from the classification. It is now being consigned to a category of "Removed Dystrophies" (Table 1) so that in the event a future publication seems to substantiate the existence of this entity, the reference publication remains readily retrievable for future use.

\section{Has the IC3D Been Accepted?}

The IC3D 2008 classification system successfully integrated the then most currently accurate clinical, pathological, and genetic information regarding corneal dystrophies. The nomenclature has been incorporated by the American Academy of Ophthalmology's widely used Basic and Clinical Science Course Series, ${ }^{30}$ which instructs ophthalmology residents in the United States and Europe and has been referenced by the National Eye Institute. Nonetheless,



$120 \mid$ www.corneajrnl.com the recommendations of the IC3D have been incorporated only in a minority of new publications. They had been cited 114 times by July 2014, according to Thomson Reuters' Web of Science, as opposed to about 800 articles published on corneal dystrophies since 2009. It is unclear whether the editors and reviewers reject the new classification, think it unimportant, or remain creatures of habit. For example, despite the nomenclature revision to GCD type 2, the name Avellino is still used, although its prevalence is seemingly decreasing. Recognizing that change is an evolutionary process, such incremental progress is encouraging.

\section{Revising the IC3D Nomenclature}

The nomenclature revision was configured to be userfriendly and easily accessible to physicians and patients on www.corneasociety.org and open access through the journal Cornea. One stated requirement of the original nomenclature revision was that it be easily "upgradeable." Six years after the original publication, sufficient new information had become available to begin our first revision of the IC3D.

\section{Changes in the 2015 IC3D}

\section{Anatomic Classification Change}

The traditionally accepted "anatomic level" corneal dystrophy classification has limitations, ${ }^{14,15}$ as dystrophies were solely assigned to the single layer most affected. Yet RBCD and TBCD affect not only the subepithelial area with destruction of the Bowman layer but also the anterior stroma and later the deeper stroma. Although categorized anatomically as "Bowman layer dystrophies," TGFBI dystrophies affect multiple layers. Other corneal dystrophies also affect more than 1 layer. MCD affects both the stroma and endothelium, and SCD involves epithelium, stroma, and endothelium. As we understand the primary cell(s) of origin, it may be less important to categorize dystrophies as being confined to 1 specific layer. In addition, histopathology, although affording improved resolution at the cellular level, is also subject to individual case and disease stage variation.

In this revision of the original IC3D from 2008, we include a proposed alteration of the century-old anatomic level classification to more accurately reflect involvement of the cellular layers. We now exclude the Bowman acellular layer and Descemet acellular membrane. Dystrophies are now divided into epithelial and subepithelial dystrophies, epithelial-stromal TGFBI dystrophies, stromal dystrophies, and endothelial dystrophies (Table 1).

\section{What We Have Removed and Added}

The IC3D elected to remove the extensive table of gene loci and genes with specific mutations because this information is rapidly changing and can be more easily obtained on the Internet. For similar reasons, a table of mutations is not included in this revision although templates still include the gene locus and gene.

The classic articles on corneal dystrophy classification by Waring, Rodrigues, and Laibson ${ }^{14,15}$ included clinical drawings and histopathologic photographs. As clinicopathological 
correlation remains a hallmark of corneal dystrophy diagnosis, we have included representative histopathology and electron microscopy, as well as confocal microscopy in some cases.

Findings on the emerging technique of anterior segment optical coherence tomography (OCT) were added to the templates when available. We expect that this method will refine clinical diagnostics of several dystrophies, especially the differential diagnosis between TBCD and RBCD by providing images that are highly similar to histopathologic sections.

\section{Reclassified Corneal Dystrophies}

\section{Congenital Hereditary Endothelial Dystrophy}

One challenge of the dystrophy nomenclature has been the tendency to emphasize a new or rare observation instead of waiting for a complete analysis of a new disorder. In the 2008 IC3D publication, we observed that "inconsistencies in the literature have confounded our understanding of precise findings in specific corneal dystrophies." Since then, we have learned more about congenital hereditary endothelial dystrophy (CHED). In 2008, we followed convention by including 2 types of CHED: an autosomal dominant (AD) form with less severe findings was called CHED1 and an autosomal recessive (AR) form with more severe findings was termed CHED2. Further review of the clinical and pathological descriptions of the 5 families previously reported with CHED1 suggests that many and possibly all of these families have PPCD. ${ }^{31-33}$ Consequently, AD CHED (CHED1) has been eliminated. Autosomal recessive CHED, previously called CHED2, is now called simply CHED. ${ }^{34}$

\section{Is the 10q23-24 Dystrophy Distinct or a Variant of TGFBI Thiel-Behnke Corneal Dystrophy?}

In 1997, Yee et $\mathrm{al}^{35}$ reported a dystrophy affecting the Bowman layer that mapped to $10 \mathrm{q} 23-24$, which they called Thiel-Behnke corneal dystrophy (TBCD). The article suggested that the affected individual had corneal findings consistent with TBCD. The histological features of this patient were subsequently reported by Lohse et $\mathrm{al}^{36}$; however, there were different pedigrees in both articles. Clarification of the $10 \mathrm{q}$ Thiel-Behnke phenotype $^{37}$ presented other challenges. Nakamura et $\mathrm{al}^{38}$ described a mixture of honeycomb-like, geographic-like, and map-like opacity patterns of the presented patients in their legends, but these were not compatible with the accompanying black and white photographs that did not demonstrate a typical honeycomb-like pattern. Consequently, given the genetic heterogeneity, phenotypic heterogeneity and absence of corroborating histopathology of the 10q23-24 dystrophy, we believe that there is insufficient evidence to consider this a variant of TBCD. Is it a distinct dystrophy? Because this is not presently known, we hope ongoing investigations will resolve this uncertainty before the next IC3D revision. The 10q23-24 dystrophy is thus still listed as a footnote to TBCD and not promoted to a template.

\section{Expanded Templates}

In 2008, the epithelial recurrent erosion dystrophy template included both Franceschetti ${ }^{39}$ hereditary recurrent erosion and Dystrophia Smolandiensis (DS) ${ }^{40}$ which shared recurrent erosions as their major and often only clinical finding. At that time, it was unclear whether these 2 entities were variants of the same condition or whether these were distinct dystrophies. Lisch et $\mathrm{al}^{41}$ observed that the affected members of the original Franceschetti's family showed recurrent erosions in the first decades, as well as diffuse subepithelial opacities in the advanced age. The authors termed this entity "Franceschetti corneal dystrophy" (FRCD). In 2009, another entity, Dystrophia Helsinglandica $(\mathrm{DH})^{42}$ was published and has been added to the epithelial recurrent erosion dystrophy's template. Future information, especially future identification of the underlying gene(s) will reveal whether these 3 entities are unique entities or allelic variants of one and the same disorder.

\section{Diagnosis of a Corneal Dystrophy in the Pediatric Patient}

Diagnosing corneal dystrophies in the pediatric patient remains a challenge. Most publications contain photographs of the most classic advanced cases found in adults. Few photographs document the earliest and most subtle corneal changes as would occur in children, and there is no atlas of corneal dystrophy findings in children. This markedly increases the difficulty of making the correct diagnosis in the pediatric patient. ${ }^{43,44}$

\section{Sporadic Corneal Dystrophy?}

It is important to be cautious before making the diagnosis of a sporadic corneal dystrophy. It is mandatory to obtain the family history and examine the parents and other family members. For example, paraproteinemic immunotactoid keratopathy can mimic SCD, lattice corneal dystrophy, or GCD type $1{ }^{45}$ Mucolipidosis IV can cause a cornea verticillata pattern similar to GCD type 1 .

\section{A PLEA TO REVIEWERS AND EDITORS}

\section{More Stringent Criteria for Publishing the New Unique Corneal Dystrophy}

An 8-year-old boy is examined and noted to have an unusual configuration of bilateral corneal flecks. Is this a unique new corneal dystrophy? There is a systematic approach to determining whether this is a corneal dystrophy that has already been described or rather a unique new entity.

Do other family members have similar corneal findings? If so, the inheritance is likely $\mathrm{AD}$ or X-linked. Even if there is no family history, family members should still be examined to detect subtle or previously unappreciated corneal changes. If no abnormalities are evident, the inheritance could be AR or there could be incomplete penetrance or poor expressivity. Although a classical phenotype-genotype correlation facilitates diagnosis, this does not always occur. Histopathology and genotyping can add more information.

If geneticists discover a new mutation, a novel type of corneal dystrophy can be constructed phenotypically. We advise peer-reviewed journals to strengthen the criteria 
required for publication of a "new" corneal dystrophy. A minimum of approximately 10 affected members in 3 generations is reasonably convincing to demonstrate a distinct dominant phenotype clinically and scientifically. Such a rigorous systematic approach also avoids creation of more category 4 dystrophies that may be destined only for eventual elimination. Corneal photographs with a dilated pupil also facilitate diagnosis. When the gene or gene locus has been identified, it is preferable to include photographs with genetic confirmation. We have attempted to do both when possible for this article.

As an example, a 27-year-old woman demonstrated rare bilateral lattice lines atypical for classic LCD. Genotyping demonstrated the classical Arg124Cys TGFBI LCD1 mutation confirming LCD. This was not a unique corneal dystrophy but rather an additional example of phenotypic variation resulting from variable penetrance or expressivity of the gene.

Regarding mutations of TGFBI, a phenotype typical enough to be clinically recognizable is generally limited to TBCD, RBCD, GCD1, GCD2, and classic LCD. When any of these classic mutations is documented, corresponding terminology should be used without exception, despite any possible individual variation in phenotype. Other TGFBI mutations often produce variant, overlapping, or mixed phenotypes, often with amyloid, and these dystrophies can be called variant LCD by IC3D conventions. Also, it is ill appreciated that both Congo red and Masson trichrome often co-label some deposits in GCD1 and LCD, suggesting a mixed phenotype or GCD2. Also in these cases, the terminology corresponding to the identified mutation should simply be used.

There are frequent submissions to journals of such "new" dystrophies based on a small change in phenotype. More than a century away from the original description of corneal dystrophies, the field has progressed from phenotype to genotype. In the United States, support of the National Eye Institute has made genotyping more accessible through eyeGENE. ${ }^{46}$ We implore authors and reviewers alike to require genotyping and phenotypic information before proposing the discovery of any new genetic disease.

\section{EPITHELIAL AND SUBEPITHELIAL DYSTROPHIES}

\section{Epithelial Basement Membrane Dystrophy (EBMD)}

Mendelian inheritance in man (MIM) \#121820.

\section{Former Alternative Names and Eponyms}

Map-dot-fingerprint dystrophy.

Cogan microcystic epithelial dystrophy.

Anterior basement membrane dystrophy.

\section{Inheritance}

Isolated familial cases have been reported. However, because the majority of cases have no documented inheritance, they are considered to be degenerative or secondary to trauma.

122 | www.corneajrnl.com

\section{Genetic Locus}

$5 \mathrm{q} 31$.

\section{Gene}

Transforming growth factor beta-induced-TGFBI in 2 families.

\section{Onset} children.

Commonly present in adult life. Rarely described in

\section{Signs}

Poor adhesion of basal epithelial cells to abnormal basal laminar material is thought to predispose to recurrent erosions.

Maps

Irregular islands of thickened, gray, hazy epithelium with scalloped, circumscribed borders, particularly affecting the central or paracentral cornea. Isolated or combined with other signs (Fig. 1A).

\section{Dots (Cogan)}

Irregular round, oval, or comma-shaped, nonstaining, putty-gray intraepithelial opacities, clustered like an archipelago in the central cornea (Fig. 1B). Typically combined with other signs, especially with maps.

\section{Fingerprint Lines}

Parallel, curvilinear lines, usually paracentral, best visualized with retroillumination (Fig. 1C). Isolated or combined with other signs, especially maps.

\section{Bleb Pattern (Bron)}

Subepithelial pattern like pebbled glass, best seen by retroillumination (Fig. 1D). Isolated or combined with other signs.

\section{Symptoms}

EBMD can be asymptomatic, associated with painful erosive episodes and/or may cause decreased vision by inducing mild irregular astigmatism (monocular diplopia, "ghost" images).

\section{Course} time.

Location and degree of pathology can fluctuate with

\section{Light Microscopy}

Maps

Sheets of intraepithelial, multilamellar, basal laminar material (Fig. 1F).

\section{Fingerprint Lines}

Rib-like intraepithelial extensions of basal laminar material (Fig. 1E).

Dots

Intraepithelial pseudocysts containing cytoplasmic debris.

Copyright (C) 2014 Wolters Kluwer Health, Inc. All rights reserved. 


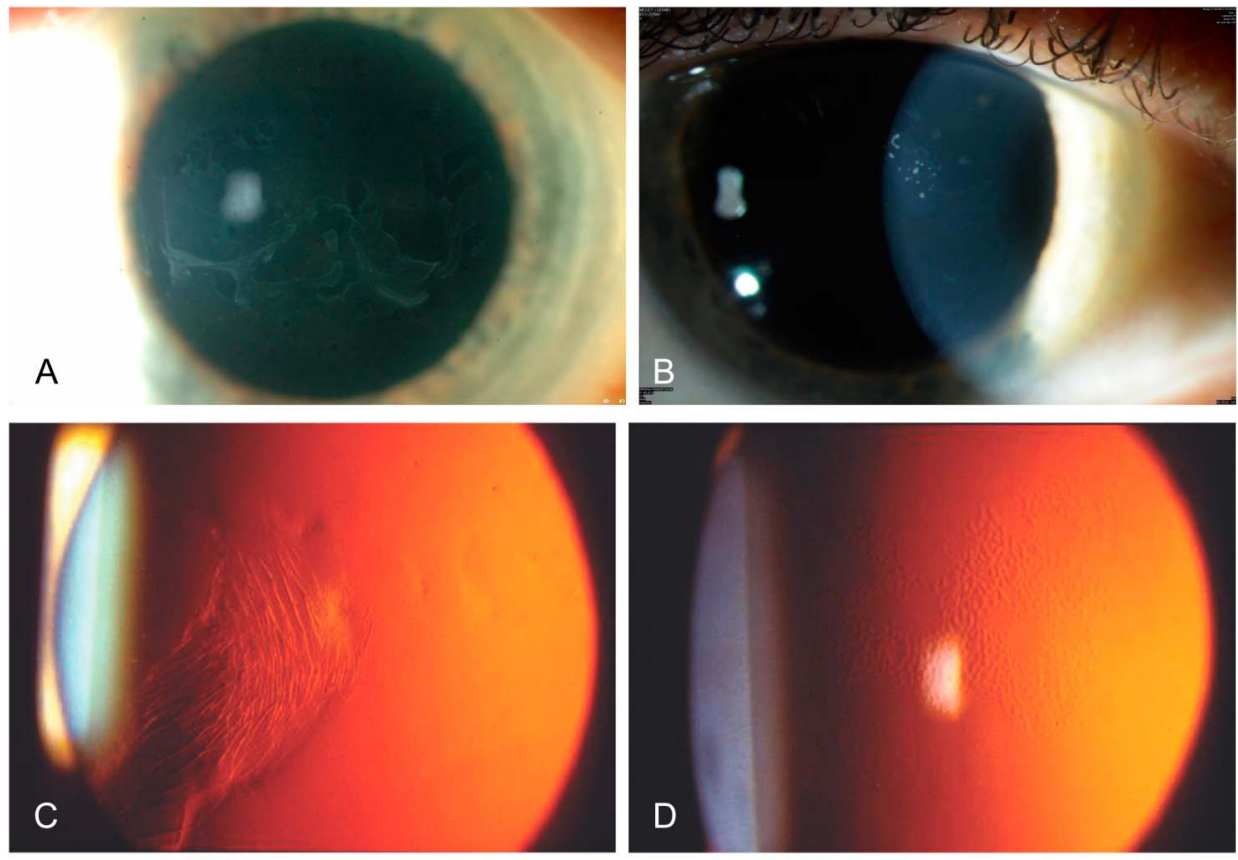

FIGURE 1. Epithelial basement membrane dystrophy. A, Map-like changes. B, Intraepithelial dot opacities (Cogan cysts) underlying map-like figures. C, Fingerprint lines, best visualized with retroillumination. D, Multiple crowded blebs (Bron), only visible in retroillumination. $E$ and $F$, Light microscopy shows excessive basement membrane material (arrowheads) intervening between distorted epithelium and the intact Bowman layer) to form redundant sheets corresponding to maps (E) and fingerprint lines $(F)(E$, Masson trichrome; F, PAS, bar $=200 \mu \mathrm{m}$.) $\mathrm{G}$, In vivo confocal microscopy demonstrates abnormal hyperreflective intraepithelial basement membrane material within suprabasal and basal epithelial cell layers $(400 \times 400 \mu \mathrm{m})$.
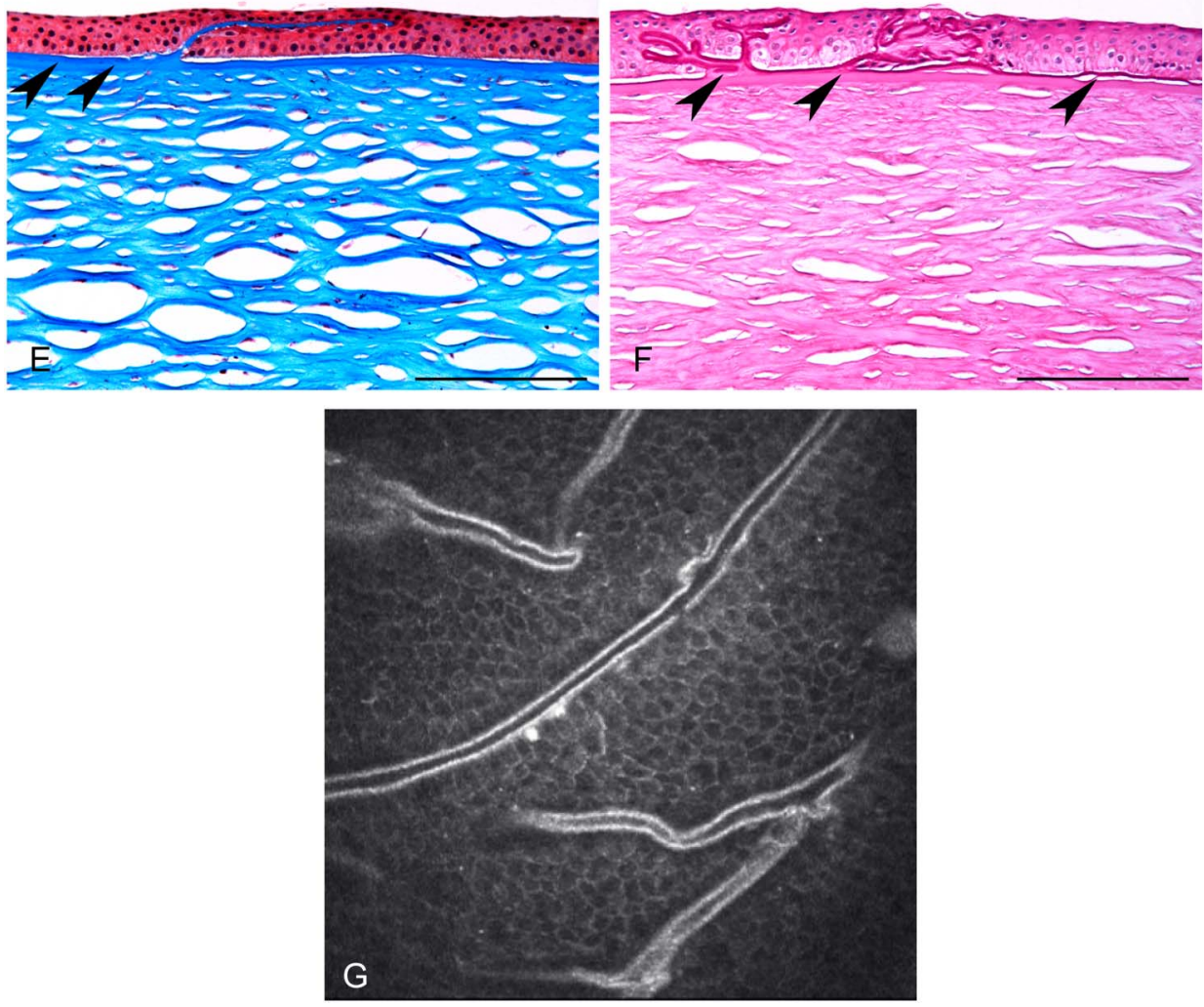

\section{Bleb Pattern} material.

Irregular, subepithelial accumulation of fibrillogranular

In contrast to some other superficial dystrophies, the Bowman layer is normal.

\section{Transmission Electron Microscopy}

Maps

Thick, multilamellar sheets $(2-6 \mathrm{~nm}$ thick) of epithelial basement membrane that extend into the epithelium. 


\section{Fingerprint Lines}

Fine fibrillar (17 $\mathrm{nm}$ diameter) and granular $(8 \mathrm{~nm})$ substance in addition to undulating waves of the basement membrane.

\section{Dots}

Intraepithelial pseudocysts contain degenerating cells with pyknotic nuclei and cytoplasmic debris.

\section{Blebs}

Discrete noncystic mounds of abnormal granular material deposited between the epithelium and Bowman layer that indents the overlying basal epithelial cells. May mimic cysts clinically, but no cysts present on histology.

\section{Confocal Microscopy}

\section{Maps}

Highly reflective tissue in various configurations corresponds to abnormal basement membrane extending into the intermediate and basal epithelial cell layers. Adjacent basal epithelial cells appear distorted. No abnormalities in superficial epithelial cells or stroma.

\section{Fingerprint Lines}

Linear hyperreflective structures corresponding to abnormal basement membrane projecting into the corneal epithelium (Fig. 1G).

\section{Dots}

Hyperreflective structures with sharp border within the intermediate cell layers.

\section{Blebs}

Circular or oval hyporeflective or hyperreflective areas at the level of the basal epithelium and Bowman layer.

\section{Category}

Most cases are sporadic and may be degenerative. Category 1 in rare cases.

Note: Only 1 publication identifies 2 families with EBMD with $T G F B I$ mutations.

\section{BIBLIOGRAPHY}

- Boutboul S, Black GC, Moore JE, et al. A subset of patients with epithelial basement membrane corneal dystrophy have mutations in TGFBI/BIGH3. Hum Mutat. 2006;27:553557.

- Bron AJ, Brown NA. Some superficial corneal disorders. Trans Ophthalmol Soc UK. 1971;91:13-29.

- Bron AJ, Tripathi RC. Cystic disorders of the corneal epithelium II. Pathogenesis. $\mathrm{Br} \quad J$ Ophthalmol. 1973;57:361-375.

- Cogan DG, Donaldson DD, Kuwabara T, et al. Microcystic dystrophy of the corneal epithelium. Trans Am Ophthalmol Soc. 1964;62:213-225.

- Guerry D. Fingerprint-like lines in the cornea. Am J Ophthalmol. 1950;33:724-726.

- Fogle JA, Kenyon KR, Stark WJ, et al. Defective epithelial adhesion in anterior corneal dystrophies. Am J Ophthalmol Soc. 1964;62:213-225.

124 | www.corneajrnl.com
- Hau SC, Tuft SJ. In vivo confocal microscopy of bleb-like disorder in epithelial basement membrane dystrophy. Cornea. 2011;30:1478-1480.

- Labbé A, De Nicola R, Dupas B, et al. Epithelial basement membrane dystrophy: evaluation with the HRT II Rostock Cornea Module. Ophthalmology. 2006;113:1301-1308.

- Laibson PR, Krachmer JH. Familial occurrence of dot (microcystic), map, fingerprint dystrophy of the cornea. Invest Ophthalmol Vis Sci. 1975;14:397-399.

- Laibson PR. Microcystic corneal dystrophy. Trans Am Ophthalmol Soc. 1976;74:488-531.

- Lisch W, Lisch C. Die epitheliale Hornhautbasalmembrandystrophie. Klin Monatsbl Augenheilkd. 1983;183:251-255.

- Munier FL, Korvatska E, Djemaï A, et al. Kerato-epithelin mutations in four 5q31-linked corneal dystrophies. Nat Genet. 1997;15:247-251.

- Rodrigues MM, Fine BS, Laibson PR, et al. Disorders of the corneal epithelium. A clinicopathologic study of dot, geographic, and fingerprint patterns. Arch Ophthalmol. 1974;92:475-482.

- Vogt A. Lehrbuch und Atlas der Spaltlampenmikroskopie des lebenden Auges (1. Teil). Berlin, Germany: Springer; 1930:119-121.

\section{Epithelial Recurrent Erosion \\ Dystrophies (EREDs) \\ MIM \#122400.}

\section{Variants}

Franceschetti corneal dystrophy (FRCD).

Dystrophia Smolandiensis (DS).

Dystrophia Helsinglandica (DH).

\section{Inheritance}

Autosomal dominant.

\section{Genetic Locus}

Unknown.

Gene

Unknown.

Onset

Early childhood.

\section{Signs}

Recurrent epithelial corneal erosions presenting in the first decades of life lasting 1 to 7 days. During pain-free intervals, no biomicroscopically evident changes are present (Fig. 2A). By mid-life, diffuse, central, subepithelial opacity, subepithelial fibrosis (Fig. 2B), or protruding keloid-like formations develop.

\section{Symptoms}

Severe epithelial erosive attacks commence in childhood and recur throughout life. The attacks often start at night. Visual impairment from central corneal opacification consequent to erosions occurs in approximately $50 \%$ of cases.

Copyright $\odot 2014$ Wolters Kluwer Health, Inc. All rights reserved. 
FIGURE 2. Franceschetti corneal dystrophy. A, In first decades of life, the cornea appears normal without any dystrophy-specific signs after recurrent epithelial erosion. $B$, With advancing age, diffuse central haze of the epithelial/subepithelial layer develops. C, Light microscopy: in advanced age, the Bowman layer (arrowhead) is partially destroyed and pannus (pan) develops between the basal epithelium and Bowman layer (PAS, $\times 200 \mu \mathrm{m})$. D, Electron microscopy of pannus with numerous fibroblasts. From Lisch W. ${ }^{41}$
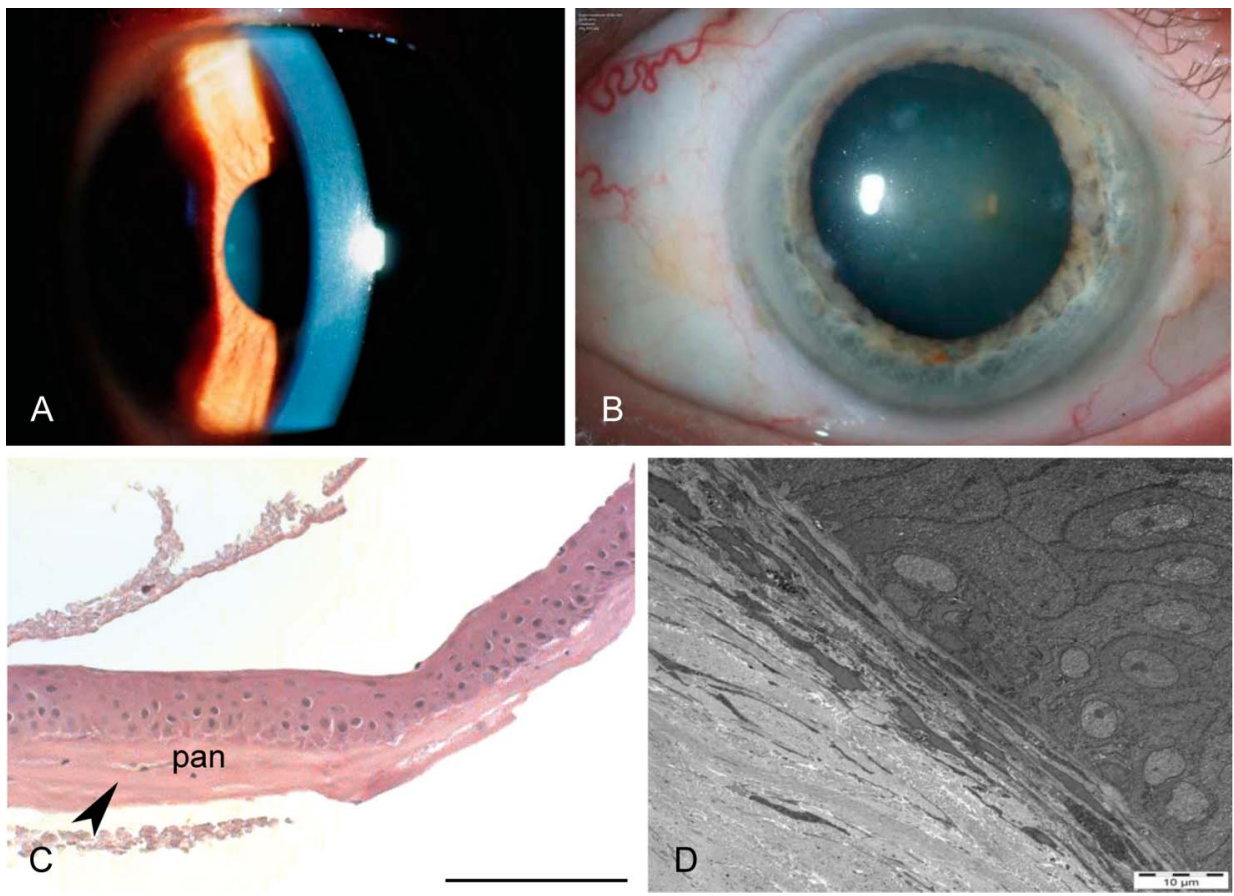

By age 30 to 40 years, corneal erosions become less severe and less frequent.

\section{Course}

With advancing age to 30 to 40 years, slow reduction in frequency of painful erosive episodes. Slow progression of central opacities impairs visual acuity.

\section{Light Microscopy FRCD}

Based on superficial perilimbal biopsy, irregular basal epithelium with enlarged intercellular spaces. Alcian bluepositive deposits were present both intracellularly and intercellularly. Partial destruction and absence of the Bowman layer with intervening avascular connective tissue pannus between the basal epithelium and Bowman layer (Fig. 2C). Negative Congo red staining.

\section{DS}

Keloid-like structure stains positive with Congo red indicating secondary amyloidosis.

\section{Transmission Electron Microscopy FRCD}

Irregularity in size and shape of the basal epithelial cells and enlarged intercellular clefts corresponding to Alcian blue-positive deposits. Presumably "dystrophic" mitochondria in between basal epithelial cells. Pannus contains numerous fibroblasts (Fig. 2D).

\section{Immunohistochemistry FRCD}

Segmental reduced expression of the tight junction proteins claudin and E-cadherin, desmosome components. Decorin expression seems to be enhanced in the basal epithelial layer compared with the normal postmortem cornea.

\section{DS}

Abundant fibronectin is present in the central subepithelial stroma, localized in areas of subepithelial fibrosis. Keratocytes in these areas are immunoreactive for S100 calcium-binding protein A4 (S100A4).

\section{Confocal Microscopy}

\section{DS}

Abnormal thinning of the corneal epithelium, absence of the Bowman layer with accumulation of pathological material at the level of the Bowman layer. Subepithelial corneal nerves are sparse and tortuous.

\section{Category}

3.

Note: The difference in severity of corneal opacification in FRCD, DS, and DH could be explained by the presence of polymorphism and difference in expressivity of a common gene. The term "Familial recurrent corneal erosions" is descriptive and not diagnostic as recurrent erosions frequently occur in other corneal dystrophies. Future DNA analyses will reveal more information about FRCD, DS, and DH and assist with differential diagnosis. 
FIGURE 3. Subepithelial mucinous corneal dystrophy. A, Slit-lamp biomicroscopy reveals that diffuse subepithelial opacities and haze are densest centrally. B, Light microscopy: a band of increased staining is present beneath the epithelium. The Bowman layer is thin (Alcian blue) $(\times 40)$. Photograph courtesy of Robert Feder, MD.


\section{BIBLIOGRAPHY}

- Franceschetti A. Hereditäre rezidivierende Erosion der Hornhaut. Z Augenheilk. 1928;66:309-316.

- Hammar B, Björck E, Lagerstedt K, et al. A new corneal disease with recurrent erosive episodes and autosomaldominant inheritance. Acta Ophthalmol. 2008;86:758-763.

- Hammar B, Björck E, Lind H, et al. Dystrophia Helsinglandica: a new type of hereditary corneal recurrent erosions with late subepithelial fibrosis. Acta Ophthalmol. 2009;87:659-665.

- Hammar B, Lagali N, Ek S, et al. Dystrophia Smolandiensis: a novel morphological picture of recurrent corneal erosions. Acta Ophthalmol. 2010;88:394-400.

- Legrand J. Dystrophie épithéliale cornéenne récidivante familiale. Bull Soc Ophtalmol. 1963;5:384-387.

- Lisch W, Bron AJ, Munier FL, et al. Franceschetti hereditary recurrent corneal erosion. Am J Ophthalmol. 2012;153:1073-1081.

- Remler O. Beitrag zur hereditären rezidivierenden Hornhauterosion. Klin Monatsbl Augenheilkd. 1983;183:59.

- Shindo S. Familial recurrent corneal erosion. Nippon Ganka Gakkai Zasshi. 1968;72:998-1004.

- Wales HJ. A family history of corneal erosions. Trans Ophthalmol Soc NZ. 1955;8:77-78.

\section{Subepithelial Mucinous Corneal Dystrophy (SMCD) \\ MIM \#612867.}

\section{Former Alternative Names and Eponyms None.}

\section{Inheritance}

Autosomal dominant inheritance most likely, but $\mathrm{X}$-linked inheritance not excluded.

\section{Genetic Locus}

Unknown.

\section{Gene}

Unknown.

Onset

First decade of life.

\section{Signs}

Diffuse bilateral subepithelial opacities and haze, most dense centrally (Fig. 3A).

126 | www.corneajrnl.com
Symptoms

Painful episodes of recurrent corneal erosions, which decrease during adolescence (only 1 publication of a single family).

\section{Course}

Progressive loss of vision in adolescence.

\section{Light Microscopy}

Subepithelial band of eosinophilic, periodic acid-Schiff (PAS)-positive, Alcian blue-positive, hyaluronidase-sensitive material is present anterior to the Bowman layer (Fig. 3B).

\section{Transmission Electron Microscopy}

Subepithelial deposits of fine fibrillar material.

\section{Immunohistochemistry}

Subepithelial deposits react for chondroitin-4-sulfate and dermatan sulfate.

\section{Confocal Microscopy}

Not reported.

\section{Category}

4.

\section{BIBLIOGRAPHY}

- Feder RS, Jay M, Yue BY, et al. Subepithelial mucinous corneal dystrophy. Clinical and pathological correlations. Arch Ophthalmol. 1993;111:1106-1114.

\section{Meesmann Corneal Dystrophy (MECD) MIM \#122100.}

Former Alternative Names and Eponyms Juvenile hereditary epithelial dystrophy.

\section{Variant}

Stocker-Holt variant.

\section{Inheritance}

Autosomal dominant.

\section{Genetic Loci}

Locus 12q13 (KRT3)

Locus 17q12 (KRT12) Stocker-Holt variant.

Copyright (C) 2014 Wolters Kluwer Health, Inc. All rights reserved. 



FIGURE 4. Meesmann corneal dystrophy. A, In direct illumination, diffuse gray, superior opacity with a distinct border is apparent. B, With retroillumination, the same eye demonstrates that the opacity pattern is composed of multiple solitary transparent microcysts. C, Multiple solitary transparent microcysts in retroillumination. D, Light microscopy: intraepithelial cysts sometimes extruding onto the corneal surface, contain amorphous material probably comprised of degenerated epithelial cells. The basement membrane is thickened (Alcian blue and hematoxylin and eosin stain, $\times 400$ ). E, Electron microscopy: intracytoplasmic fibrillar peculiar substance, surrounding tangles of filaments. F, In vivo confocal microscopy shows hyporeflective areas corresponding to microcysts in the basal epithelial layer and round hyperreflective structures $(400 \times$ $400 \mu \mathrm{m})$. Figures $4 \mathrm{~A}, \mathrm{~B}$, and $\mathrm{C}$ from Figures 4A and B: Weiss JS, Møller HU, Lisch W, et al. The IC3D classification of the corneal dystrophies. Cornea. 2008;27(suppl 2):S1-S42.
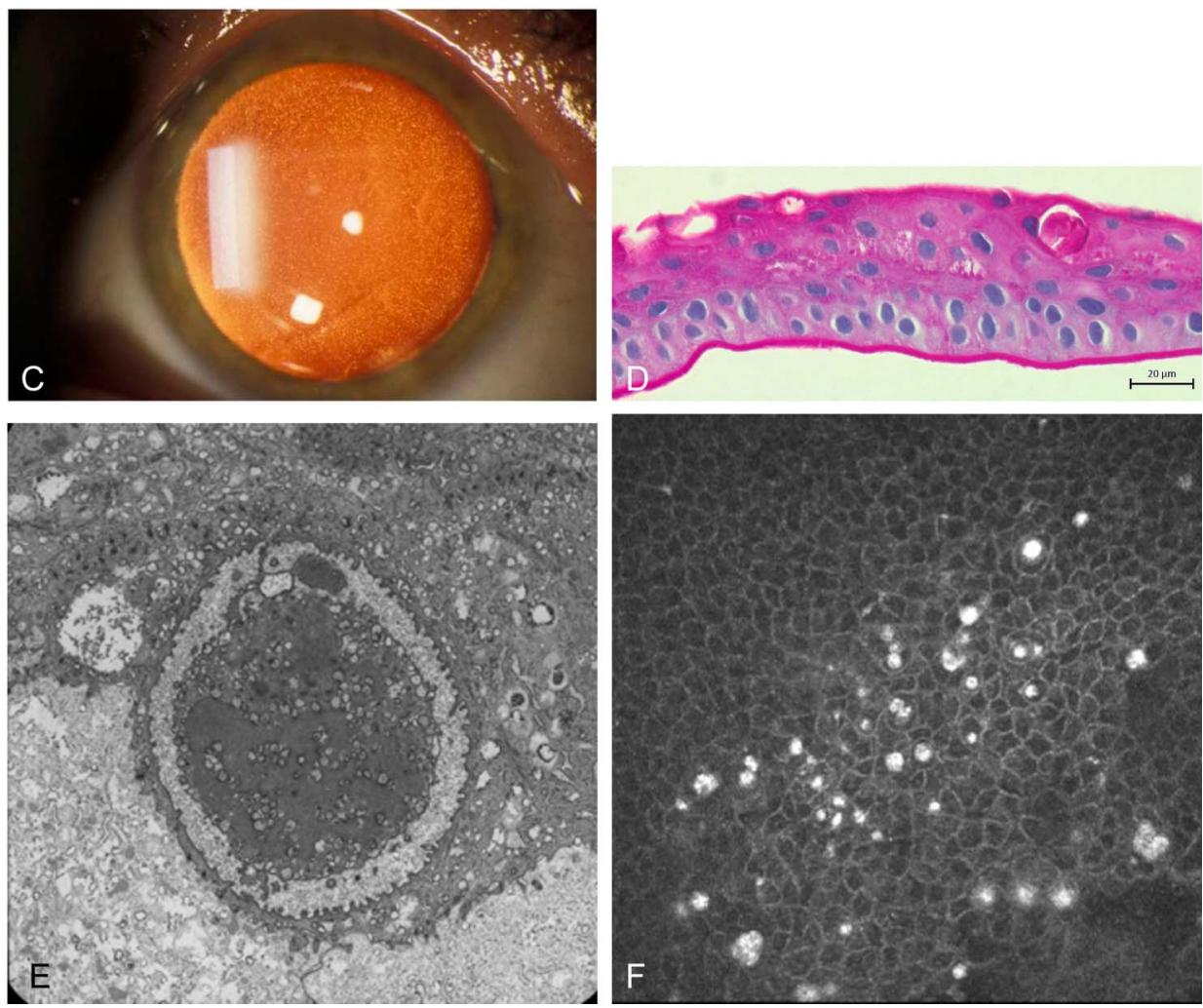

\section{Genes}

Keratin K3 (KRT3).

Keratin K12 (KRT12) Stocker-Holt variant.

\section{Onset}

Early childhood.

\section{Signs}

Multiple, tiny intraepithelial vesicles extend to the limbus and are most numerous in the interpalpebral area with clear surrounding epithelium. Direct illumination shows varying diffuse gray opacities in different patterns, which may have a distinct border (Fig. 4A). Areas of the central or peripheral cornea may be unaffected. Whorled and wedge-shaped epithelial patterns have been reported. The gray opacities appear as solitary transparent cysts on indirect illumination (Figs. 4B, C). Approximately $85 \%$ of eyes show microcysts affecting the entire epithelium, while the remainder are localized in the upper, lower, central, and/or peripheral cornea. Coalescence of several cysts may result in refractile linear opacities with an intervening clear cornea The cornea may be slightly thinned and corneal sensation may be reduced.

\section{Stocker-Holt Variant}

The entire cornea demonstrates fine grayish punctate epithelial opacities that stain with fluorescein and fine linear opacities that may appear in a whorl pattern.

\section{Symptoms}

Patients are typically asymptomatic or may have mild visual reduction, although some patients complain of glare and light sensitivity. Foreign body sensation or tearing may escalate to painful recurrent epithelial erosions. Rarely, blurred vision results from corneal irregularity and scarring. 


\section{Stocker-Holt Variant}

Patients demonstrate more severe signs and symptoms with earlier onset compared with classic Meesmann corneal dystrophy.

\section{Course}

Stationary or slowly progressive.

\section{Light Microscopy}

The thickened and disorganized epithelium always demonstrates intraepithelial cysts (Fig. 4D) filled with PASpositive cellular debris, which fluoresces. The cells also contain of PAS-positive and diastase-sensitive material (glycogen). A thickened multilaminar basement membrane projects into the basal epithelium.

\section{Stocker-Holt Variant}

Variably thickened epithelium with vacuolated and degenerating cells. Variably thickened basement membrane extends into the epithelium. The Bowman layer and stroma remain normal.

\section{Transmission Electron Microscopy}

Intracytoplasmic "peculiar substance" represents a focal collection of fibrogranular material surrounded by tangles of cytoplasmic filaments (Fig. 4E). These cysts are round and uniform $(10-50 \mu \mathrm{m})$. Some lesions with reflective points in the cytoplasm probably correspond to cell nuclei.

\section{Stocker-Holt Variant}

Not reported.

\section{Confocal Microscopy}

Hyporeflective areas in the basal epithelium ranging from 40 to $150 \mu \mathrm{m}$ in diameter, some with reflective spots inside (Fig. 4F).

Numerous corneal intraepithelial microcysts and hyperreflective material thought to represent degenerative cells have been detected closer to the basal layer of the corneal epithelium in older patients. Compared with the basal epithelial layer, the superficial layer contains larger microcysts with atrophic changes of the hyperreflective material. Clearly visualized demarcation lines between the microcysts and normal epithelial cells correspond to the biomicroscopically visible demarcation between clear and affected areas.

\section{Stocker-Holt Variant}

Not reported.

\section{Category}

1 including Stocker-Holt variant.

\section{BIBLIOGRAPHY}

- Allen EH, Atkinson SD, Liao H, et al. Allele-specific siRNA silencing for the common keratin 12 founder mutation in Meesmann epithelial corneal dystrophy. Invest Ophthalmol Vis Sci. 2013;54:494-502.
- Behnke H, Thiel HJ. On hereditary epithelial dystrophy of the cornea (type Meesmann-Wilke) in Schleswig-Holstein. Klin Monatsbl Augenheilkd. 1965;147:662-672.

- Burns RP. Meesmann's corneal dystrophy. Trans Am Ophthalmol Soc. 1968;66:530-635.

- Cao W, Yan M, Hao Q, et al. Autosomal-dominant Meesmann epithelial corneal dystrophy without an exon mutation in the keratin-3 or keratin-12 gene in a Chinese family. J Int Med Res. 2013;41:511-518.

- Clausen I, Duncker GI, Grünauer-Kloevekorn C. Identification of a novel mutation in the cornea specific keratin 12 gene causing Meesmann's corneal dystrophy in a German family. Mol Vis. 2010;16:954-960.

- Cremona FA, Ghosheh FR, Laibson PR, et al. Meesmann corneal dystrophy associated with epithelial basement membrane and posterior polymorphous corneal dystrophies. Cornea. 2008;27:374-377.

- Ehlers N, Hjortdal J, Nielsen K, et al. Phenotypic variability in Meesmann's dystrophy: clinical review of the literature and presentation of a family genetically identical to the original family. Acta Ophthalmol. 2008;86:40-44.

- Fine BS, Yanoff M, Pitts E, et al. Meesmann's epithelial dystrophy of the cornea. Am J Ophthalmol. 1977;83:633642.

- Hassan H, Thaung C, Ebenezer ND, et al. Severe Meesmann's epithelial corneal dystrophy phenotype due to a missense mutation in the helix-initiation motif of keratin 12. Eye (Lond). 2013;27:367-373.

- Javadi MA, Rezaei-Kanavi M, Javadi A, et al. Meesmann corneal dystrophy; a clinico-pathologic, ultrastructural and confocal scan report. J Ophthalmic Vis Res. 2010;5:122126.

- Meesmann A. Über eine bisher nicht beschriebene dominant vererbte Dystrophia epithelialis corneae. Ber Zusammenkunft Dtsch Ophthalmol Ges. 1938;52:154-158.

- Nielsen K, Orntoft T, Hjortdal J, et al. A novel mutation as the basis for asymptomatic Meesmann dystrophy in a Danish family. Cornea. 2008;27:100-102.

- Ogasawara M, Matsumoto Y, Hayashi T, et al. KRT12 mutations and in vivo confocal microscopy in two Japanese families with Meesmann corneal dystrophy. Am J Ophthalmol. 2014;157:93-102.

- Seto T, Fujiki K, Kishishita H, et al. A novel mutation in the cornea-specific Keratin 12 gene in Meesmann corneal dystrophy. Jpn J Ophthalmol. 2008;52:224-226.

- Stocker FW, Holt LB. A rare form of hereditary epithelial dystrophy of the cornea: a genetic, clinical and pathologic study. Trans Am Ophthalmol Soc. 1954;52:133-144.

- Sullivan LS, Baylin EB, Font R, et al. A novel mutation of the Keratin 12 gene responsible for a severe phenotype of Meesmann's corneal dystrophy. Mol Vis. 2007;13:975-980.

- Szaflik JP, Ołdak M, Maksym RB, et al. Genetics of Meesmann corneal dystrophy: a novel mutation in the keratin 3 gene in an asymptomatic family suggests genotype-phenotype correlation. Mol Vis. 2008;14:17131718.

- Thiel HJ, Behnke H. On the extent of variation of hereditary epithelial corneal dystrophy (Meesmann-Wilke type). Ophthalmologica. 1968;155:81-86. 

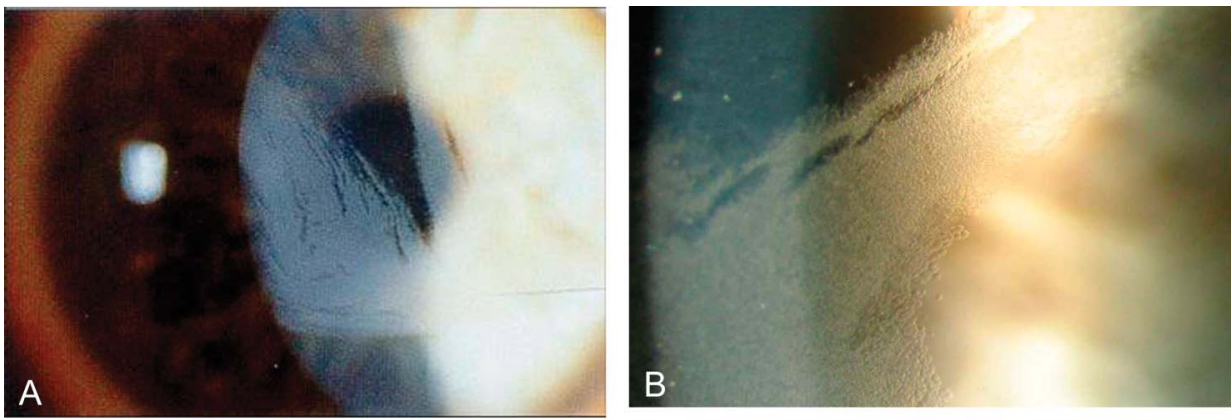

FIGURE 5. Lisch epithelial corneal dystrophy. A and B, Diffuse grayish epithelial opacities form radial, feathery or club-shaped patterns. C, Opacification consists of crowded, transparent microcysts in retroillumination. D, Light microscopy: pronounced vacuolization of the epithelial cells, particularly in outer layers (hematoxylin and eosin stain, $\times 250)$. E, Electron microscopy: discloses coalescent intracellular vacuolization of the wing cells. Some of these vacuoles coalesce to form empty spaces within the cytoplasm of the epithelial cells, $\times 4000$. F, In vivo confocal microscopy shows intraepithelial hyperreflective dystrophic areas containing hyporeflective round structures, sharply demarcated from normal epithelial areas $(400 \times 400 \mu \mathrm{m})$. Figure $5 \mathrm{C}$ from Figure $5 \mathrm{C}$ in Weiss JS, Møller HU, Lisch W, et al. The IC3D classification of the corneal dystrophies. Cornea. 2008;27(suppl 2):S1-S42.
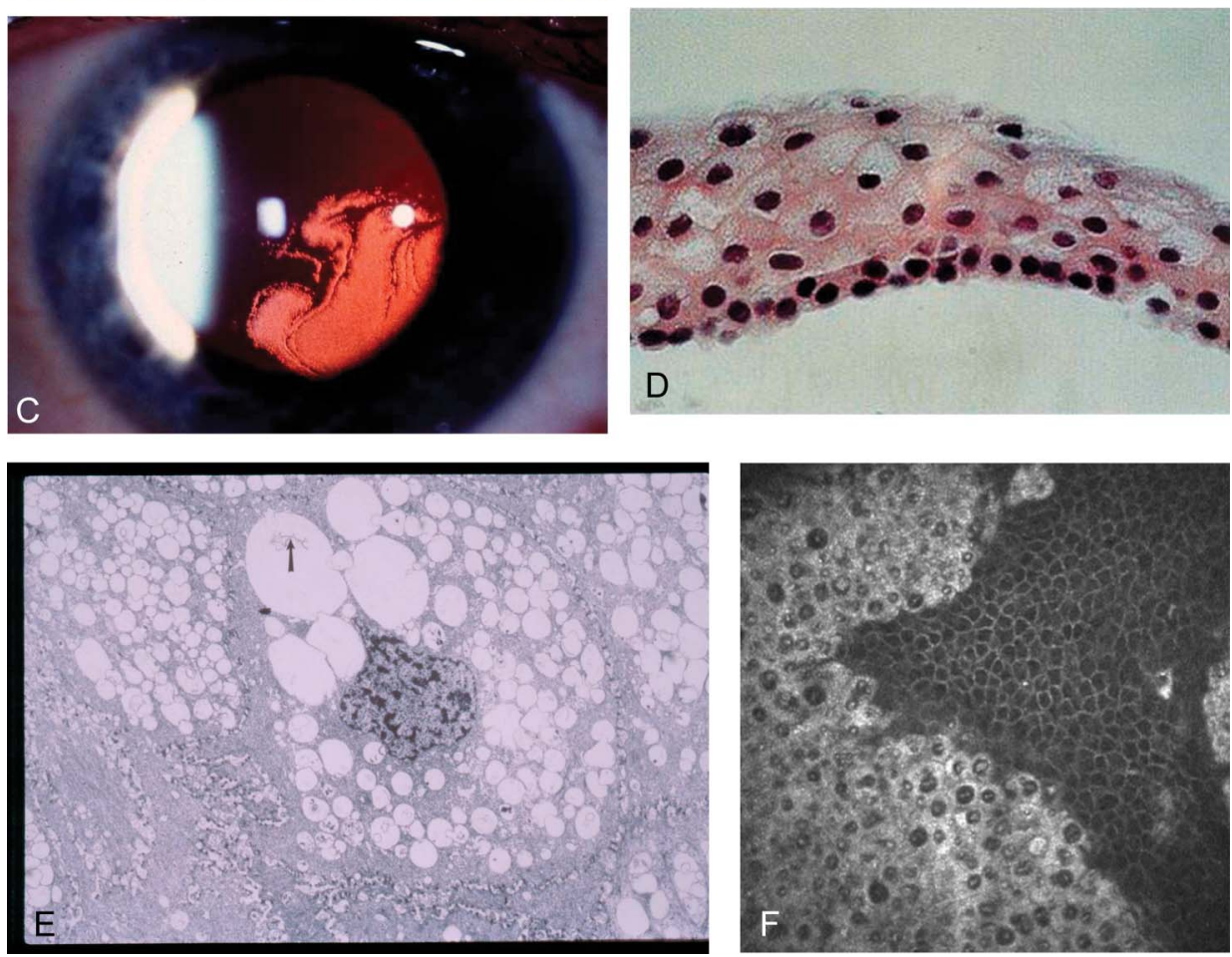

- Tuft S, Bron AJ. Imaging the microstructural abnormalities of Meesmann corneal dystrophy by in vivo confocal microscopy. Cornea. 2006;25:868-870.

- Wittebol-Post D, van Bijsterveld OP, Delleman JW. Meesmann's epithelial dystrophy of the cornea. Biometrics and a hypothesis. Ophthalmologica. 1987;194:44-49.

- Yeung JY, Hodge WG. Recurrent Meesmann's corneal dystrophy: treatment with keratectomy and mitomycin C. Can J Ophthalmol. 2009;44:103-104.

\section{Lisch Epithelial Corneal Dystrophy (LECD) MIM \#300778.}

\section{Former alternative names and eponyms}

Band-shaped and whorled microcystic dystrophy of the corneal epithelium.

\section{Inheritance}

X-chromosomal dominant.
Genetic Locus

$\mathrm{Xp} 22.3$.

Gene

Unknown.

\section{Onset}

Childhood.

\section{Signs}

Direct illumination shows localized gray opacities in different patterns: whorl-like, radial, band-shaped flame/ feathery, and club shaped (Figs. 5A, B). Indirect illumination demonstrates multiple densely crowded clear cysts (Fig. 5C). Opacities can be minimal or asymmetric with clear surrounding epithelium. Similar appearance in males and females.

\section{Symptoms} involved.

Asymptomatic or blurred vision if the pupillary axis is www.corneajrnl.com | 129 


\section{Course}

Slow progression of opacities with possible visual deterioration.

\section{Light Microscopy}

Epithelial basal cells are cuboidal with low nuclear to cytoplasmic ratio. In the suprabasal and parabasal layers, vacuolated cells (Fig. 5D) progress to the epithelial surface, where they adopt elongated flat squamous shapes. These vacuoles are PAS positive, diastase labile, Luxol fast blue and Sudan black negative, consistent with glycogen. Intercellular cysts, parakeratosis, orthokeratosis, and hyperkeratosis are not identified.

\section{Transmission Electron Microscopy}

Basal epithelial cells with intact basement membrane and hemidesmosomes are unremarkable. In the midlevel and superficial epithelium, there are cells with myriad vacuoles and inclusions (Fig. 5E) of 2 forms; vaguely flocculent or lamellar material with or without a circumscribing membrane, and more electron-dense whorled or membranous structures.

\section{Confocal Microscopy}

There are 4 characteristic features of the abnormal epithelial cells: highly hyperreflective cytoplasm and hyporeflective nuclei (Fig. 5F); uniform involvement of all epithelial layers within the affected areas; welldemarcated borders with adjacent normal epithelium; involvement of the limbal area. No distinct intracellular deposits are present, although the cytoplasm has granular hyperreflectivity.

\section{Category}

2 .

\section{BIBLIOGRAPHY}

- Butros S, Lang GK, Alvarez de Toledo J, et al. Die verschiedenen Trübungsmuster der Lisch-Hornhautdystrophie. Klin Monatsbl Augenheilkd. 2006;223:837-840.

- Charles NC, Young JA, Kunar A, et al. Band-shaped and whorled microcystic dystrophy of the corneal epithelium. Ophthalmology. 2000;107:1761-1764.
FIGURE 6. Gelatinous drop-like corneal dystrophy. A, Band keratopathy type. B, Mulberry type. C, Fluorescein staining shows an extremely hyperpermeable corneal epithelium, here without superficial punctate keratopathy or erosion. D, Kumquat-like diffuse stromal opacity. E, Light microscopy: massive amyloid in a subepithelial lesion (arrowheads) extending to the midstromal cornea. Bar $=400 \mu \mathrm{m}$ (direct fast scarlet [DFS], $\times 10)$. Figures $6 \mathrm{~A}, \mathrm{~B}$, and D from Figures $6 \mathrm{~A}, \mathrm{~B}$, and $\mathrm{C}$ in Weiss JS, Møller HU, Lisch W, et al. The IC3D classification of the corneal dystrophies. Cornea. 2008;27(suppl 2):S1-S42.

130 | www.corneajrnl.com
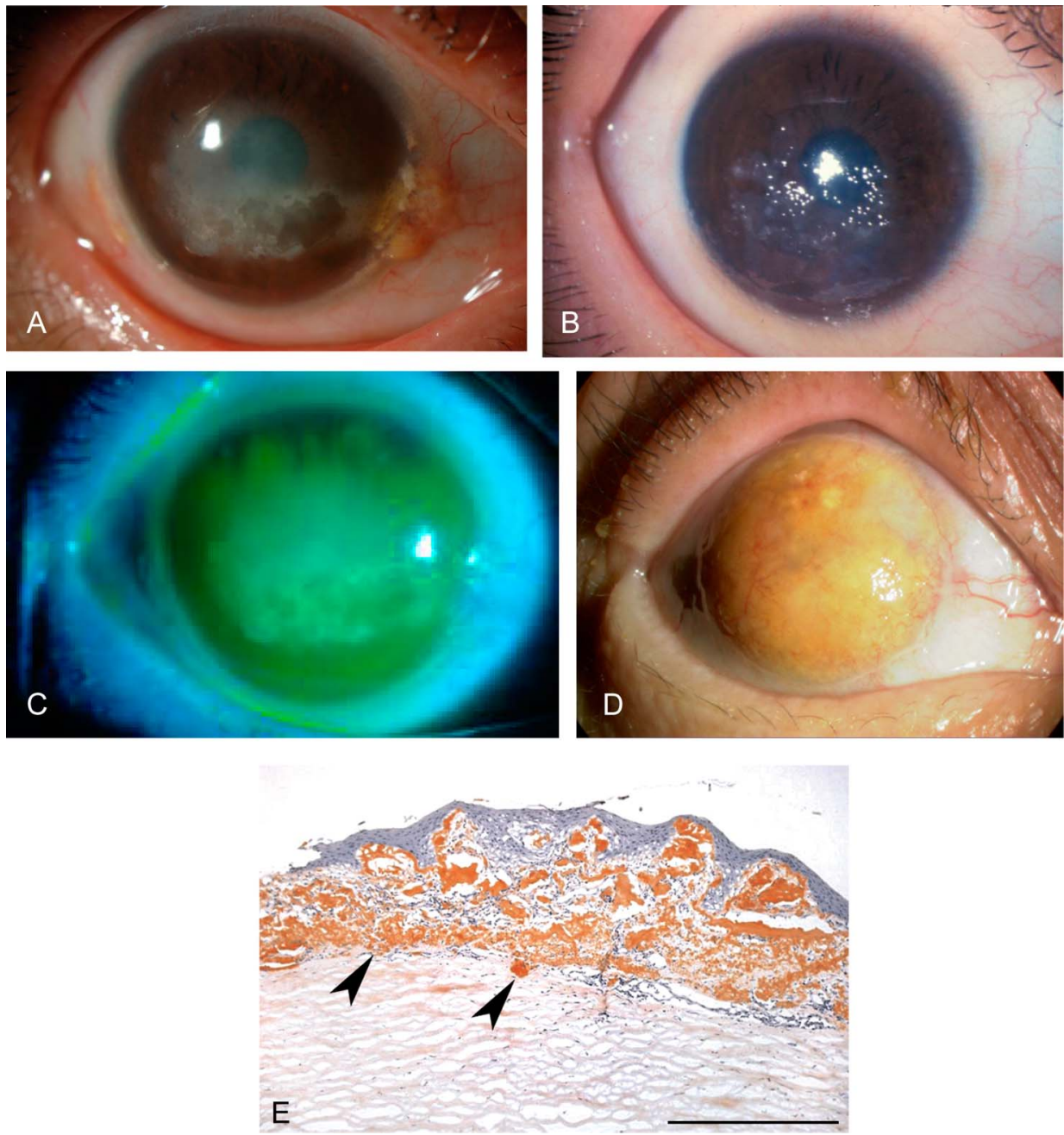

Copyright (c) 2014 Wolters Kluwer Health, Inc. All rights reserved. 
- Kurbanyan K, Sejpal KD, Aldave AJ, et al. In vivo confocal microscopic findings in Lisch corneal dystrophy. Cornea. 2012;31:437-441.

- Lisch W, Büttner A, Offner F, et al. Lisch corneal dystrophy is genetically distinct from Meesmann corneal dystrophy and maps to Xp22.3. Am J Ophthalmol. 2000;130:461-468.

- Lisch W, Steuhl KP, Lisch C, et al. A new, band-shaped and whorled microcystic dystrophy of the corneal epithelium. Am J Ophthalmol. 1992;114:35-44.

- Robin SB, Epstein RJ, Kornmehl EW. Band-shaped, whorled microcystic corneal dystrophy. Am J Ophthalmol. 1994;117:543-544.

- Wessel MM, Sarkar JS, Jakobiec FA, et al. Treatment of Lisch corneal dystrophy with photorefractive keratectomy and Mitomycin C. Cornea. 2011;30:481-485.

\section{Gelatinous Drop-like Corneal Dystrophy (GDLD) MIM \#204870.}

\section{Former Alternative Names and Eponyms}

Subepithelial amyloidosis.

Primary familial amyloidosis (Grayson).

\section{Inheritance}

Autosomal recessive.

\section{Genetic Locus \\ $1 \mathrm{p} 32$.}

\section{Gene}

Tumor-associated calcium signal transducer 2 (TACSTD2, previously $M 1 S 1$ ).

\section{Onset}

First to second decade.

\section{Signs}

Initially, subepithelial lesions may appear similar to bandshaped keratopathy (Fig. 6A) or there may be groups of small multiple nodules, that is, mulberry configuration (Fig. 6B). They stain with fluorescein (Fig. 6C), indicating epithelial hyperpermeability. Superficial vascularization is frequently seen. In later life, patients may also develop stromal opacification or develop larger nodular, kumquat-like lesions (Fig. 6D) although it is uncertain whether there is a transition of the 4 different phenotypes from one to the other with time.

\section{Symptoms}

Significant decrease in vision, photophobia, irritation, redness, and tearing.

\section{Course}

Progression of protruding subepithelial deposits and stromal opacity. Most patients develop recurrence after superficial keratectomy, lamellar keratoplasty, or penetrating keratoplasty, typically within a few years.

\section{Light Microscopy \\ Subepithelial and stromal amyloid deposits (Fig. 6E).}

\section{Transmission Electron Microscopy}

Disruption of epithelial tight junctions in the superficial epithelium. Amyloid evident in the basal epithelial layer.

\section{Immunohistochemistry}

Deposits stain with antibodies to lactoferrin.

\section{Confocal Microscopy}

Epithelial cells are irregular in shape and often elongated. There is a mild disorganization of the overall epithelial architecture. Large accumulations of brightly reflective material are noted within or beneath the epithelium and within the anterior stroma. No evident abnormalities can be detected in the posterior cornea.

\section{Category}

1.

\section{BIBLIOGRAPHY}

- Fujiki K, Nakayasu K, Kanai A. Corneal dystrophies in Japan. J Hum Genet. 2011;46:431-435.

- Ide T, Nishida K, Maeda N, et al. A spectrum of clinical manifestations of gelatinous drop-like corneal dystrophy in Japan. Am J Ophthalmol. 2004;137:1081-1084.

- Kaji Y, Oshika T, Takazawa Y, et al. Co-localization of advanced glycation end products and D-beta-aspartic acidcontaining proteins in gelatinous drop-like corneal dystrophy. Br J Ophthalmol. 2012;96:1127-1131.

- Kinoshita S, Nishida K, Dota A, et al. Epithelial barrier function and ultrastructure of gelatinous drop-like corneal dystrophy. Cornea. 2000;19:551-555.

- Kitazawa K, Kawasaki S, Shinomiya K, et al. Establishment of a human corneal epithelial line lacking the functional TACSTD2 gene as an in vitro model for gelatinous drop-like dystrophy. Invest Ophthalmol Vis Sci. 2013;5701-5711.

- Klintworth GK, Valnickova Z, Kielar RA, et al. Familial subepithelial corneal amyloidosis - a lactoferrin-related amyloidosis. Invest Ophthalmol Vis Sci. 1997;38:27562763.

- Nakaizumi GA. A rare case of corneal dystrophy. Acta Soc Ophthalmol Jpn. 1914;18:949-950.

- Nakatsukasa M, Kawasaki S, Yamasaki K, et al. Tumorassociated calcium signal transducer 2 is required for the proper subcellular localization of claudin 1 and 7: implications in the pathogenesis of gelatinous drop-like corneal dystrophy. Am J Pathol. 2010;177:1344-1355.

- Nakatsukasa M, Kawasaki S, Yamasaki K, et al. Two novel mutations of TACSTD2 found in three Japanese gelatinous drop-like corneal dystrophy families with their aberrant subcellular localization. Mol Vis. 2011;19:965-970.

- Paliwal P, Gupta J, Tandon R, et al. Identification and characterization of a novel TACSTD2 mutation in gelatinous drop-like corneal dystrophy. Mol Vis. 2010;16:729739 .

- Ren Z, Lin PY, Klintworth GK, et al. Allelic and locus heterogeneity in autosomal recessive gelatinous drop-like corneal dystrophy. Hum Genet. 2002;110:568-577. 
FIGURE 7. Reis-Bücklers corneal dystrophy. A, Confluent irregular, geographic-like opacities. B, Geographic opacities extend to the limbus and deeper stroma in a more advanced case. C, Light microscopy: Masson trichrome stains keratohyalin intensely red beneath the epithelium and between superficial stromal lamellae. Note characteristic destruction of the Bowman layer. Deeper red spots (asterisk) are artifact of lamellar keratoplasty (Arg124Leu TGFBI mutation), bar $=200 \mu \mathrm{m}$. D, Electron microscopy: broad band of irregularly arranged, subepithelial rod-shaped bodies $(\times 3000)$. E, In vivo confocal microscopy shows a granular highly reflective material without any shadow within the basal epithelium (Arg124Leu mutation) $(400 \times 400$ $\mu \mathrm{m})$.

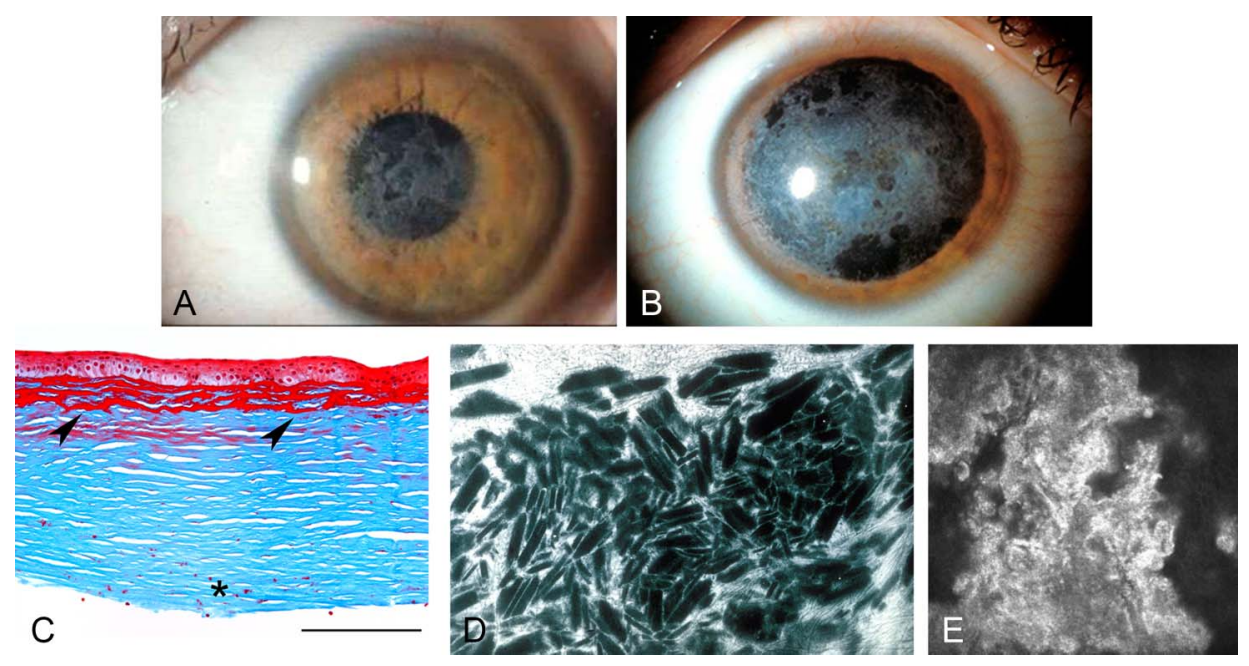

- Tsujikawa M, Kurahashi H, Tanaka T, et al. Identification of the gene responsible for gelatinous drop-like corneal dystrophy. Nat Genet. 1999;21:420-423.

- Tsujikawa M. Gelatinous drop-like corneal dystrophy. Cornea. 2012;31(suppl 1):S37-S40.

- Yoshida S, Kumano Y, Yoshida A, et al. Two brothers with gelatinous drop-like dystrophy at different stages of the disease: role of mutational analysis. Ophthalmol. 2002; 133:830-832.

\section{EPITHELIAL-STROMAL TGFBI DYSTROPHIES}

\section{Reis-Bücklers Corneal Dystrophy MIM \#608470.}

\section{Former Alternative Names and Eponyms}

Corneal dystrophy of Bowman layer, type I (CDB I). Geographic corneal dystrophy (Weidle).

Atypical Granular Corneal Dystrophy.

Granular Corneal Dystrophy, type 3.

Anterior limiting membrane dystrophy, type 1 .

Superficial Granular Corneal Dystrophy.

\section{Inheritance}

Autosomal dominant.

\section{Genetic Locus}

$5 q 31$.

\section{Gene}

Transforming growth factor beta-induced-TGFBI.

\section{Onset}

\section{Childhood.}

\section{Signs}

Confluent early irregular geographic-like opacities with varying densities develop at the level of the Bowman layer and superficial stroma, initially discrete (Fig. 7A) and subsequently extending to the limbus and deeper stroma (Fig. 7B). Can be confused with TBCD especially in the first 2 decades. In this early stage, RBCD shows more irregular diffuse opacities with clear interruptions, whereas TBCD exhibits multiple flecks with reticular formation.

\section{Symptoms}

Vision is impaired from childhood. Painful recurrent corneal erosions.

\section{Course}

Slowly progressive deterioration of vision. Recurrent corneal erosions tend to abate with time. Similar but frequently more aggressive course than TBCD but may not be able to distinguish in an individual case.

\section{Light Microscopy}

The Bowman layer is replaced by a sheet-like layer of granular Masson trichrome-red deposits (Fig. 7C), which can extend to the subepithelial stroma and, in advanced cases, sparse round deposits appear in the middle and posterior stroma.

\section{Transmission Electron Microscopy}

Subepithelial electron-dense, rod- or trapezoidal-shaped bodies identical to those in GCD1 (Fig. 7D) replace the Bowman layer and extend from the basal epithelial cell level to anterior stroma and, sparsely, to deeper stroma. Basal epithelial cells may contain vesicles with similar rods. Electron microscopy is necessary for definitive histopathologic diagnosis to distinguish from TBCD, which demonstrates curly fibers not rod-shaped bodies.

\section{Immunohistochemistry}

Rod-shaped bodies are immunopositive for transforming growth factor beta-induced protein (keratoepithelin). 


\section{Optical Coherence Tomography}

A homogenous confluent layer of hyperreflective deposits often with serrated anterior border is apparent at the level of the Bowman layer and anterior stroma. It is thickest in the center $(72-132 \mu \mathrm{m})$, becomes thinner in midperiphery, and disappears toward the limbus.

\section{Confocal Microscopy}

Distinct deposits are found in the epithelium and Bowman layer. The deposits in the suprabasal and basal epithelial cell layer show extremely high reflectivity from small granular or amorphous material without shadows (Fig. 7E). The Bowman layer is replaced by highly reflective irregular material, even more reflective than in TBCD. Fine diffuse round or spindle-shaped deposits may be noted in the anterior and sparsely even in the posterior stroma.

\section{Category}

1.

\section{BIBLIOGRAPHY}

- Bücklers M. Über eine weitere familiäre Hornhautdystrophie (Reis). Klin Monatsbl Augenkeilkd. 1949;114:386-397.

- Kobayashi A, Sugiyama K. In vivo laser confocal microscopy findings for Bowman's layer dystrophies (Thiel-Behnke and Reis-Bücklers corneal dystrophies). Ophthalmology. 2007;114:69-75.

- Konishi M, Yamada M, Nakamura Y, et al. Immunohistology of keratoepithelin in corneal stromal dystrophies associated with R124 mutations of the BIGH3 gene. Curr Eye Res. 2000;21:891-896.

- Küchle M, Green WR, Völcker HE, et al. Reevaluation of corneal dystrophies of Bowman's layer and the anterior stroma (Reis-Bücklers and Thiel-Behnke types): a light and electron microscopic study of eight corneas and a review of the literature. Cornea. 1995;14:333-354.

- Liang Q, Pan Z, Sun X, Baudouin C, et al. Reis-Bücklers corneal dystrophy: a reappraisal using in vivo and ex vivo imaging techniques. Ophthalmic Res. 2014;51:187-195.

- Munier FL, Korvatska E, Djemaï A, et al. Keratoepithelin mutations in four 5q31-linked corneal dystrophies. Nat Genet. 1997;15:247-251.

- Reis W. Familiäre, fleckige Hornhautentartung. Dtsch Med Wochenschr. 1917;43:575.

- Ridgway AE, Akhtar S, Munier FL, et al. Ultrastructural and molecular analysis of Bowman's layer corneal dystrophies: an epithelial origin? Invest Ophthalmol Vis Sci. 2000;41:3286-3292.

- Small KW, Mullen L, Barletta J, et al. Mapping of ReisBücklers corneal dystrophy to chromosome 5q. $\mathrm{Am} \mathrm{J}$ Ophthalmol. 1996;121:384-390.

- Stone EM, Mathers WD, Rosenwasser GO, et al. Three autosomal dominant corneal dystrophies map to chromosome 5q. Nat Genet. 1994;6:47-51.

- Streeten BW, Qi Y, Klintworth GK, et al. Immunolocalization of beta ig-h3 protein in 5q31-linked corneal dystrophies and normal corneas. Arch Ophthalmol. 1999;117:67-75.
- Weidle EG. Klinische und feingewebliche Abgrenzung der Reis-Bücklers'schen Hornhautdystrophie. Klin Monatsbl Augenheilkd. 1989;194:217-226.

- Wittbol-Post D, Pels E. The dystrophy described by Reis and Bücklers. Ophthalmologica. 1989;199:1-9.

\section{Thiel-Behnke Corneal Dystrophy (TBCD)} MIM \#602082.

\section{Former Alternative Names and Eponyms}

Corneal dystrophy of Bowman layer, type II (CDB2). Honeycomb-shaped corneal dystrophy.

Anterior limiting membrane dystrophy, type II. Curly fibers corneal dystrophy. Waardenburg-Jonkers corneal dystrophy.

\section{Inheritance}

Autosomal dominant.

\section{Genetic Loci}

$5 \mathrm{q} 31$.

\section{Gene}

Transforming growth factor beta-induced-TGFBI.

\section{Onset}

$$
\text { Early childhood. }
$$

\section{Signs}

Initial signs are solitary flecks or irregularly shaped scattered opacities at the level of the Bowman layer, followed by symmetrical subepithelial honeycomb opacities (Figs. 8A, $\mathrm{B}, \mathrm{Ci}$ ) with peripheral cornea typically uninvolved. In older patients, opacities can progress to deeper stromal layers and the corneal periphery. It is difficult to distinguish from ReisBücklers corneal dystrophy (RBCD) in early or individual cases.

Rare alleles that combine Arg555Gln with other TGFBI mutations lead to variants of TBCD with atypical opacities.

\section{Symptoms}

Recurrent corneal erosions may be painful in the first and second decades. Gradual visual impairment develops later. Erosions are less frequent, and the onset of visual impairment is later than in RBCD.

\section{Course}

Slowly progressive deterioration of vision results from increasing corneal scarring. Recurrent corneal erosions diminish with time. Similar but frequently less aggressive course than RBCD but difficult to distinguish individual cases.

\section{Light Microscopy}

Alternating irregular thickening and thinning of the epithelial layer to compensate for ridges and furrows of underlying stroma, with focal absence of the epithelial basement membrane (Fig. 8D). The Bowman layer is replaced 



FIGURE 8. Lattice Corneal Dystrophy, type 1 (LCD). A, Initial signs of mild honeycomb appearance. B, Intensive honeycomb opacity pattern in advanced disease (Arg555GIn mutation). C, In a 42 year-old with genetically confirmed TBCD: (i) the cornea displays honeycomb opacity while (ii) confocal microscopy demonstrates the sawtooth pattern of hyperreflective material in the Bowman layer. D, Light microscopy: varying thickness of the epithelium due to a thickened abnormal subepithelial fibrous layer (arrowheads) that replaces the Bowman layer and has a characteristic sawtooth-like surface. Masson trichrome, bar $=200 \mu \mathrm{m}$. E, Transmission electron microscopy: subepithelial curly filaments with a thickness of $10 \mathrm{~nm}(\times 50,000)$. F, In vivo confocal microscopy image shows abnormal hyperreflective material with homogeneous reflectivity, round edges, and dark shadows within the basal epithelium $(400 \times 400 \mu \mathrm{m})$.


Cii

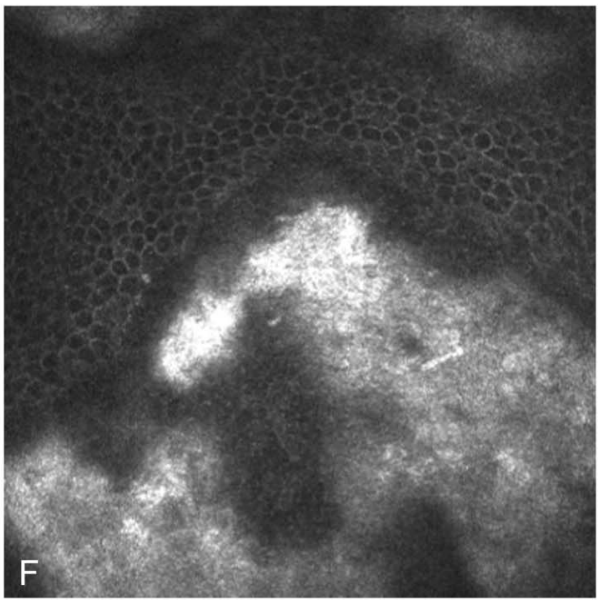

by a superficial fibrocellular pannus with a pathognomonic wavy sawtoothed pattern.

\section{Transmission Electron Microscopy}

Presence of curly collagen fibers 9 to $15 \mathrm{~nm}$ in diameter (Fig. 8E), importantly distinguishes TBCD from RBCD.

\section{Immunohistochemistry}

Curly fibers are immunopositive for transforming growth factor beta-induced protein (keratoepithelin).

134 | www.corneajrnl.com

\section{Confocal Microscopy}

Distinct deposits are found in the epithelium and Bowman layer. The deposits in the basal epithelial cell layer show homogeneous reflectivity with round edges accompanying dark shadows (Fig. 8F). The Bowman layer is replaced with reflective irregular material that is less reflective than in RBCD.

\section{Optical Coherence Tomography}

Prominent hyperreflective material at the level of the Bowman layer extending into the epithelium in a characteristic

Copyright (C) 2014 Wolters Kluwer Health, Inc. All rights reserved. 
sawtooth pattern (Fig. 8Cii), a major feature in distinguishing TBCD from RBCD.

\section{Category}

1.

Note: Linkage to $10 \mathrm{q} 24$ has been reported in 1 family. The initial and later descriptions of the phenotype are incomplete and variable, and light microscopic, immunohistochemical, and anterior segment optical coherence tomographic evidence of subepithelial scarring similar to and consistent with TBCD has not been published.

\section{BIBLIOGRAPHY}

- Chen YJ, Chen JT, Lu DW, et al. In vivo corneal confocal microscopic findings and gene analysis of three patients with Thiel-Behnke corneal dystrophy. $\mathrm{Br} J$ Ophthalmol. 2010;94:262-264.

- Cho KJ, Mok JW, Na KS, et al. TGFBI gene mutations in a Korean population with corneal dystrophy. Mol Vis. 2012;18:2012-2021.

- Kobayashi A, Sugiyama K. In vivo laser confocal microscopy findings for Bowman's layer dystrophies (Thiel-Behnke and Reis-Bücklers corneal dystrophies). Ophthalmology. 2007;114:69-75.

- Küchle M, Green WR, Völcker HE, et al. Reevaluation of corneal dystrophies of Bowman's layer and the anterior stroma (Reis-Bücklers and Thiel-Behnke types): a light and electron microscopic study of eight corneas and a review of the literature. Cornea. 1995;14:333-354.

- Lohse E, Stock EL, Jones JC, et al. Reis-Bücklers' corneal dystrophy. Immunofluorescent and electron microscopic studies. Cornea. 1989;8:200-209.

- Munier FL, Korvatska E, Djemaï A, et al. Keratoepithelin mutations in four 5q31-linked corneal dystrophies. Nat Genet. 1997;15:247-251.

- Niel-Butschi F, Kantelip B, Iwaszkiewicz J, et al. Genotype-phenotype correlations of TGFBI p.Leu509Pro, p.Leu509Arg, p.Val613Gly, and the allelic association of p.Met502Val-p.Arg555Gln mutations. Mol Vis. 2011;17:1192-1202.

- Nowińska AK, Wylegala E, Janiszewska DA, et al. Genotype-phenotype correlation of TGFBI corneal dystrophies in Polish patients. Mol Vis. 2011;17:2333-2342.

- Ridgway AE, Akhtar S, Munier FL, et al. Ultrastructural and molecular analysis of Bowman's layer corneal dystrophies: an epithelial origin? Invest Ophthalmol Vis Sci. 2000;41:32863292.

- Streeten BW, Qi Y, Klintworth GK, et al. Immunolocalization of beta ig-h3 protein in 5q31-linked corneal dystrophies and normal corneas. Arch Ophthalmol. 1999;117:67-75.

- Thiel HJ, Behnke H. Eine bisher unbekannte subepitheliale hereditäre Hornhautdystrophie. Klin Monatsbl Augenheilkd. 1967;150:862-874.

- Vajzovic LM, Karp CL, Haft P, et al. Ultra high-resolution anterior segment optical coherence tomography in the evaluation of anterior corneal dystrophies and degenerations. Ophthalmology. 2011;118:1291-1296.

- Weidle EG. Die wabenförmige Hornhautdystrophie (ThielBehnke) Neubewertung und Abgrenzung gegenüber der
Reis-Bücklerschen Hornhautdystrophie. Klin Monatsbl Augenheilkd. 1999;214:125-135.

- Wittebol-Post D, Van Schooneveld MJ, Pels E. The corneal dystrophy of Waardenburg and Jonkers. Ophthalmic Paediatr Genet. 1989;10:249-255.

\section{Lattice Corneal Dystrophy, type 1 (Classic) (LCD1) and Variants}

MIM \#122200.

\section{Former Alternative Names and Eponyms}

LCD, type 1.

Biber-Haab-Dimmer.

\section{Inheritance}

Autosomal dominant.

\section{Genetic Locus}

$5 \mathrm{q} 31$.

\section{Gene}

Transforming growth factor beta-induced-TGFBI.

\section{Onset}

First to second decade.

\section{Signs}

The first signs are central superficial fleck-like opacities that usually develop by the end of the first decade (Fig. 9A). In retroillumination, isolated peripheral, few, and subtle lattice lines in deeper layers are visible initially in the superficial stroma of the same patient (Fig. 9B). Thin branching refractile lines and/or subepithelial, whitish, ovoid dots also develop by the end of the first decade. These lines start centrally and more superficially, spreading centrifugally and deeply, but leaving the far peripheral stroma, Descemet membrane and the endothelium uninvolved (Figs. 9C, D). Diffuse subepithelial ground-glass haze of the central and paracentral cornea develops concurrently with the lattice lines in the central and paracentral cornea and subsequently progresses (Fig. 9C), accompanied by recurrent erosions. Development of diffuse central haze in the second to third decade may reduce vision sufficiently to necessitate surgical intervention. The number of lattice lines may differ between the 2 eyes (unilateral cases are described). Variant LCD, type IIIA also shows central thicker lattice lines (Fig. 10A), whereas LCD, type IV is characterized more by deeper deposits without epithelial erosion (Fig. 10B).

\section{Symptoms}

Ocular discomfort, pain, and visual impairment, sometimes start as early as the first decade as consequent to frequent recurrent erosive attacks. Visual impairment within the fourth decade.

\section{Course}

Progressive, often with marked visual decrease by the fourth decade. 

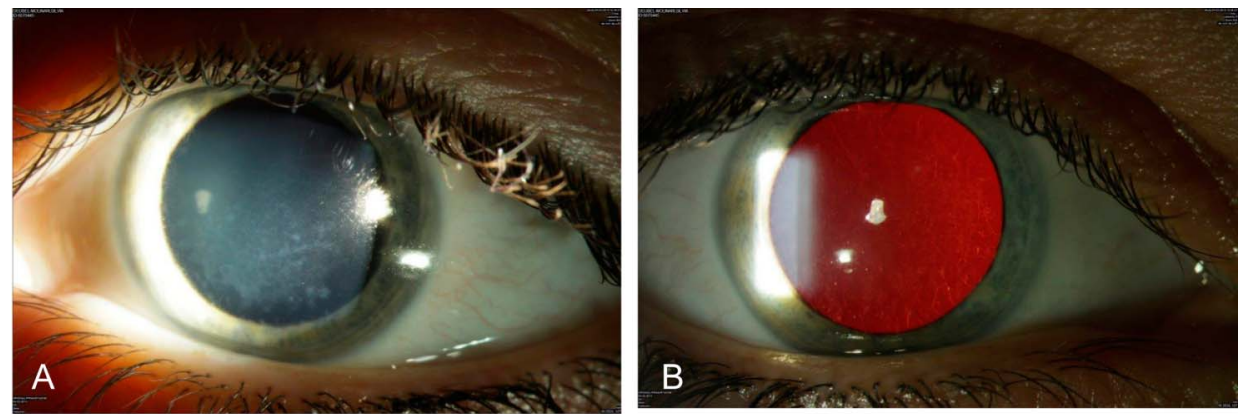

FIGURE 9. Lattice corneal dystrophy, type 1 (classic lattice). Direct (A) and retroillumination (B) of early lattice corneal dystrophy (LCD) with dots and fine lattice lines with genetic confirmation of Arg124Cys in TGFBI. C, Subepithelial groundglass haze of the central and inferior cornea, and diffuse lattice lines in advanced LCD with genetic confirmation of Arg124Cys in TGFBI. D, Dots and paracentral lattice lines in retroillumination with genetic confirmation of Arg124Cys in TGFBI. E, Light microscopy: Congo red (E) prominently stains a continuous layer of amyloid (asterisk) that underlies and partially destroys the Bowman layer and intrastromal amyloid deposits corresponding to lattice lines (arrowheads). F, This same section viewed with polarized light confirms deposits are birefringent and red-green dichroic, thus amyloid. Arg124Cys TGFBI mutation, bars $=200 \mu \mathrm{m}$. G, In vivo confocal microscopy image shows filaments corresponding to lattice lines within the stroma $(400 \times 400$ $\mu \mathrm{m})$. Figure 9D from Figure 10A, in Weiss JS, Møller HU, Lisch W, et al. The IC3D classification of the corneal dystrophies. Cornea. 2008;27(suppl 2):S1-S42.
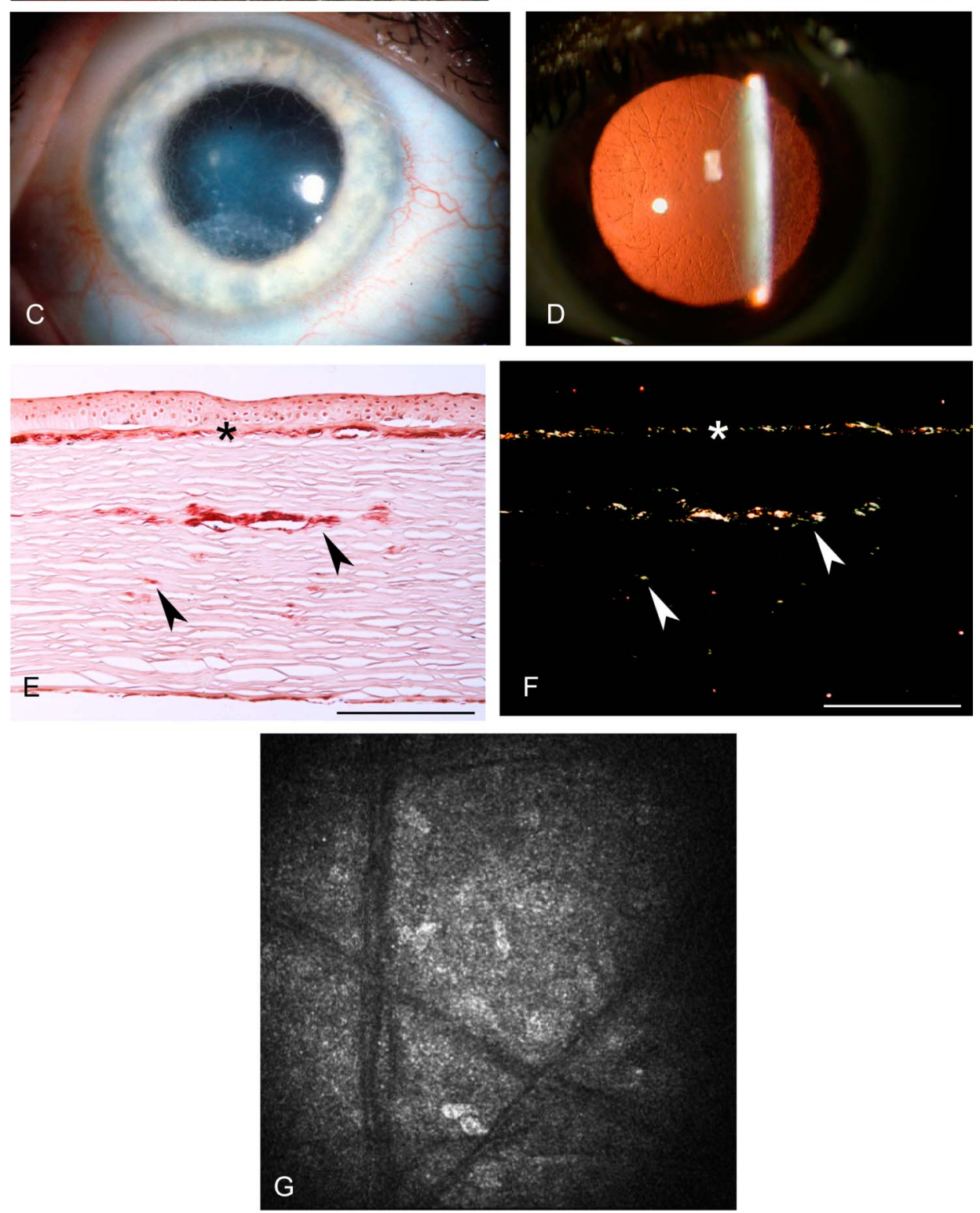

\section{Light Microscopy}

Epithelial atrophy and disruption with degeneration of basal epithelial cells, focal thinning, or absence of the Bowman layer, progress with age. Eosinophilic amyloid material accumulates between the epithelial basement membrane and Bowman layer. Stromal deposition of amyloid

distorts the architecture of corneal lamellae. Amyloid deposits characteristically stain positive with Congo red (Fig. 9E), and display birefringence and red-green di rhos under polarized light (Fig. 9F). Also, deposits exhibit metachromasia with crystal violet and fluorescence with the use of thioflavin $\mathrm{T}$ staining.

Copyright (C) 2014 Wolters Kluwer Health, Inc. All rights reserved. 
FIGURE 10. Lattice dystrophy variants. A, Type IIIA with central thicker ropy-appearing lattice lines extending to the limbus. B, Type IV with minimal findings of central fleck-like opacities in deeper cornea and few small lattice lines. Epithelial erosions are typically absent because there is posterior-to-anterior corneal progression.
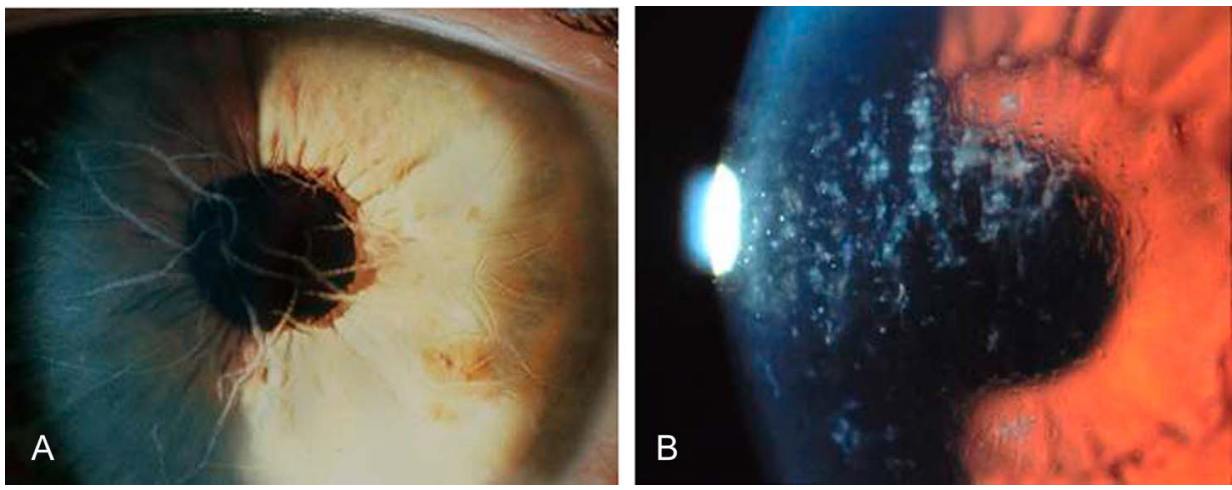

\section{Transmission Electron Microscopy}

Extracellular masses of fine, electron-dense randomly aligned fibrils of uniform 8 to $10 \mathrm{~nm}$ diameter are characteristic of amyloid protein. There are fewer keratocytes in the areas of amyloid deposition: some are degenerated with cytoplasmic vacuolization, whereas others appear metabolically active. Descemet membrane and the endothelium are normal.

\section{Confocal Microscopy}

Linear and branching structures (Fig. 9G) in stroma with changing reflectivity and poorly demarcated margins. Such lines must be differentiated from other similar images (ie, fungi).

\section{Category}

1 .

Note: The LCD variants (Figs. 10A, B) are caused by more than 2 dozen distinct heterozygous amyloidogenic mutations, nearly all of which are located in the fourth FAS1 domain of $T G F B I$. LCD variants (previously designated type IIIA, I/IIIA, $\mathrm{IV}$, and polymorphic amyloidosis) have a delayed onset compared with classic LCD. The lattice lines may be larger, with a limbus to limbus ropy appearance (type IIIA), thinner (type I/IIIA), smaller (type IV) or even absent (polymorphic amyloidosis), although one has to keep in mind that the lattice pattern is very much dependent on age and mutation. Some patients do not have clinically evident lattice lines. Corneal epithelial erosions are a typical presenting sign of LCD, types IIIA and I/IIIA, but are virtually absent in others (type IV and polymorphic corneal amyloidosis). The frequency of recurrent erosions is more common in subtypes that progress from anterior to posterior (types IIIA and I/IIIA) compared with those progress from posterior to anterior (type IV). Although classic LCD has been found in numerous countries, LCD variants are mostly geographically restricted. For example, LCD type IIIA and LCD type IV were reported predominantly in Japan and Italy, and the 2 LCD type IV variants were reported to be derived from solitary founder mutations in Japan and Italy.

Historically, multiple subtypes of lattice were created on the basis of phenotypic and genotypic variations. The so-called lattice corneal dystrophy type 2 (LCD2) is a misnomer, in fact comprising systemic amyloidosis plus corneal lattice lines and should be termed familial amyloidosis, Finnish type, or gelsolin type. Eponymously, it is known as Meretoja syndrome (Figs. 11A, B).

\section{BIBLIOGRAPHY}

- Biber H. Ueber einige seltene Hornhautkrankungen: die oberflaechliche gittrige Keratitis [Inaugural dissertation]. Zurich;1890.

- Chiou AG, Beuermann RW, Kaufman SC, et al. Confocal microscopy in lattice corneal dystrophy. Graefes Arch Clin Exp Ophthalmol. 1999;237:697-701.
FIGURE 11. Familial amyloidosis (Meretoja syndrome). A, Lax, masklike facies consequent to cranial nerve VII palsy. B, Lattice lines are less numerous than in classic and variant $L C D$, start peripherally, and spread centrally (Images provided for differential diagnostic purposes).

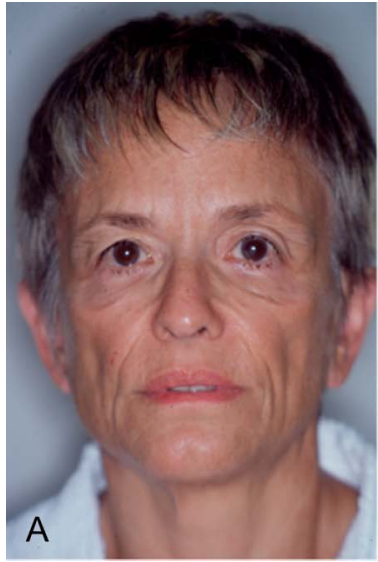


- Dighiero P, Drunat S, Ellies P, et al. A new mutation (A546T) of the big-h3 gene responsible for a French lattice corneal dystrophy type IIIA. Am J Ophthalmol. 2000;129:248-251.

- Dighiero P, Niel F, Ellies P, et al. Histologic phenotypegenotype correlation of corneal dystrophies associated with eight distinct mutations in the TGFBI gene. Ophthalmology. 2001;108:818-823.

- Ellies P, Renard G, Valleix S, et al. Clinical outcome of eight BIGH3-linked corneal dystrophies. Ophthalmology. 2002;109:793-797.

- Fujiki K, Hotta Y, Nakayasu K, et al. A new L527R mutation of the beta IGH3 gene in patients with lattice corneal dystrophy with deep stromal opacities. Hum Genet. 1998;103:286-289.

- Fukuoka H, Kawasaki S, Yamasaki K, et al. Lattice corneal dystrophy type IV (p.Leu527Arg) is caused by a founder mutation of the TGFBI gene in a single Japanese ancestor. Invest Ophthalmol Vis Sci. 2010;51:4523-4530.

- Funayama T, Mashima Y, Kawashima M, et al. Lattice corneal dystrophy type III in patients with a homozygous L527R mutation in the TGFBI gene. Jpn J Ophthalmol. 2006;50:62-64.

- Hida T, Proia AD, Kigasawa K, et al. Histopathologic and immunochemical features of lattice corneal dystrophy type III. Am J Ophthalmol. 1987;104:249-254.

- Hotta Y, Fujiki K, Ono K, et al. Arg124Cys mutation of the betaig-h3 gene in a Japanese family with lattice corneal dystrophy type I. Jpn J Ophthalmol. 1998;42:450-455.

- Kannabiran C, Klintworth GK. TGFBI gene mutations in corneal dystrophies. Hum Mutat. 2006;27:615-625.

- Kawamoto K, Morishige N, Yamada N, et al. Delayed corneal epithelial wound healing after penetrating keratoplasty in individuals with lattice corneal dystrophy. $\mathrm{Am} \mathrm{J}$ Ophthalmol. 2006;142:173-174.

- Klintworth GK, Bao W, Afshari NA, et al. Two mutations in the TGFBI (BIGH3) gene associated with lattice corneal dystrophy in an extensively studied family. Invest Ophthalmol Vis Sci. 2004:45:1382-1388.

- Munier FL, Frueh BE, Othenin-Girard P, et al. BIGH3 mutation spectrum in corneal dystrophies. Invest Ophthalmol Vis Sci. 2002;43:949-954.

- Munier FL, Korvatska E, Djemaï A, et al. Keratoepithelin mutations in four 5q31-linked corneal dystrophies. Nat Genet. 1997;15:247-251.

- Nakagawa AS, Fujiki K, Enomoto Y, et al. Case of late onset and isolated lattice corneal dystrophy with Asn544Ser (N544S) mutation of transforming growth factor betainduced (TGFBI, BIGH3) gene. Nippon Ganka Gakkai Zasshi. 2004;108:618-620.

- Schmitt-Bernard CF, Guittard C, Arnaud B, et al. BIGH3 exon 14 mutations lead to intermediate type I/IIIA of lattice corneal dystrophies. Invest Ophthalmol Vis Sci. 2000;41:1302-1308.

- Seitz B, Weidle E, Naumann GOH. Einseitige gittrige stromale Hornhautdystrophie Typ III (Hida). Klin Monatsbl Augenheilkd. 1993;203:279-285.

- Snead DR, Mathews BN. Differences in amyloid deposition in primary and recurrent corneal lattice dystrophy type 1 . Cornea. 2002;21:308-311.

138 | www.corneajrnl.com
- Stewart H, Black GCM, Donnai D, et al. A mutation within exon 14 of the TGFBI (BIGH3) gene on chromosome 5q31 causes an asymmetric, late-onset form of lattice corneal dystrophy. Ophthalmology. 1999;106:964-970.

- Stix B, Leber M, Bingemer P, et al. Hereditary lattice corneal dystrophy is associated with corneal amyloid deposits enclosing C-terminal fragments of keratoepithelin. Invest Ophthalmol Vis Sci. 2005;46:1133-1139.

- Stock EL, Feder RS, O'Grady RB, et al. Lattice corneal dystrophy type IIIA. Clinical and histopathologic correlations. Arch Ophthalmol. 1991;109:354-358.

- Suesskind D, Auw-Haedrich C, Schorderet DF, et al. Keratoepithelin in secondary corneal amyloidosis. Graefes Arch Clin Exp Ophthalmol. 2006;244:725-731.

- Tian X, Fujiki K, Wang W, et al. Novel mutation (V505D) of the TGFBI gene found in a Chinese family with lattice corneal dystrophy, type I. Jpn J Ophthalmol. 2005;49:84-88.

- Tsujikawa K, Tsujikawa M, Yamamoto S, et al. Allelic homogeneity due to a founder mutation in Japanese patients with lattice corneal dystrophy type IIIA. Am J Med Genet. 2002;113:20-22.

- Yamada N, Chikama TI, Morishige N, et al. Homozygous mutation (L527R) of TGFBI in an individual with lattice corneal dystrophy. Br J Ophthalmol. 2005;89:771-773.

- Yamamoto S, Okada M, Tsujikawa M, et al. A keratoepithelin (big-h3) mutation in lattice corneal dystrophy type IIIA. Am J Hum Genet. 1998;62:719-722.

- Yamamoto S, Okada M, Tsujikawa M, et al. The spectrum of beta ig-h3 gene mutations in Japanese patients with corneal dystrophy. Cornea. 2000;19(3 suppl):S21-S23.

\section{Granular Corneal Dystrophy, type 1 (Classic) (GCD1) \\ MIM \#121900.}

\section{Former Alternative Names and Eponyms}

Corneal dystrophy Groenouw type I.

\section{Inheritance}

Autosomal dominant.

\section{Genetic Locus}

$5 \mathrm{q} 31$.

Gene

Transforming growth factor beta-induced-TGFBI.

\section{Onset}

Childhood, as early as 2 years of age.

Signs

In children, a vortex pattern (Fig. 12A) of brownish granules develops superficial to the Bowman layer. As the patient ages, well-defined granules appear white on direct illumination with clear intervening stroma (Fig. 12B). The size and number of granules increase resulting in snowflake appearance (Fig. 12C and D). On retroillumination, these granules are composed of extremely small, translucent dots with 

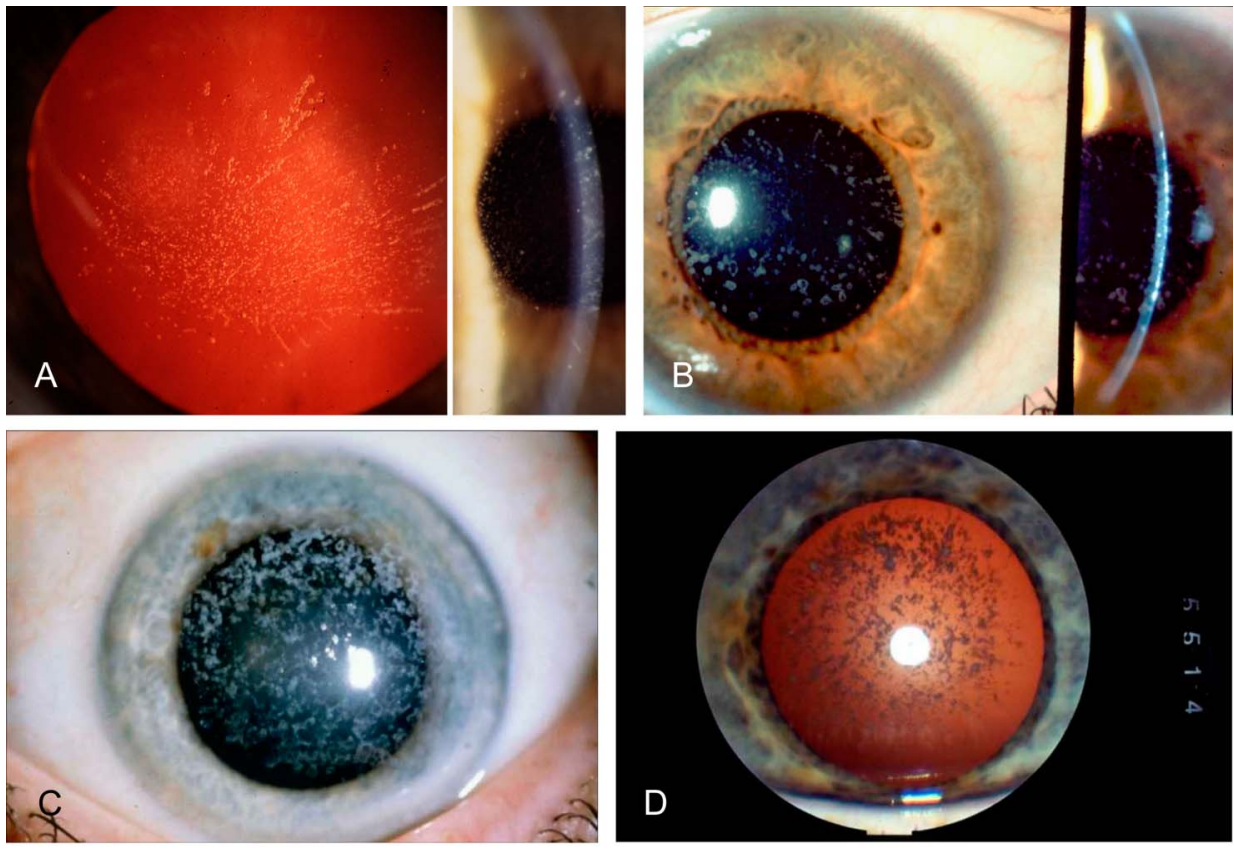

FIGURE 12. GCD, type 1 (GCD1). $A$, In a child, early subepithelial verticillate-like opacities are evident by retro and direct illumination. B, With broad slit illumination, stromal deposits are both discrete and confluent, and are axially distributed in anterior stroma. C and D, In an adult, more prominent diffuse granular opacities in the form of "snowfall" are apparent with direct (C) and retroillumination (D). E, Light microscopy-Masson trichrome highlights deposits of keratohyalin at various stromal layers and partial destruction of the Bowman layer (between arrowheads). Arg555Trp TGFBI mutation, bar $=240$ $\mu \mathrm{m}$. Figures $12 \mathrm{~B}$ and $\mathrm{C}$ from Figures $12 \mathrm{~A}$ and $\mathrm{B}$ in Weiss JS, Møller HU, Lisch $W$, et al. The IC 3D classification of the corneal dystrophies. Cornea. 2008;27(suppl 2):S1-S42.

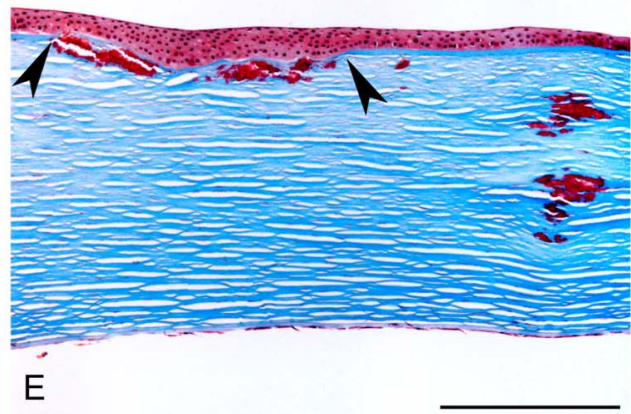

the appearance of vacuoles, glassy splinters, or crushed bread crumbs. Opacities do not extend to the limbus. In later life, granules extend into the deeper stroma approaching Descemet membrane. Homozygotes have more severe manifestations.

\section{Symptoms}

Glare and photophobia are early symptoms. Visual acuity decreases as opacification progresses with age. Recurrent erosions are seen frequently. Homozygote cases have more severe symptoms.

\section{Course}

With progression, opacities become more confluent in the superficial cornea and reduce visual acuity. Serial observation over time demonstrates in both GCD1 and GCD2 that granule drop out after epithelial erosions may actually result in stromal clearing.

\section{Light Microscopy}

Multiple stromal deposits may extend from deep epithelium to Descemet membrane. Hyaline opacities stain with Masson trichrome (Fig. 12E).

\section{Transmission Electron Microscopy}

Dense rod-shaped bodies are similar in appearance to those in Reis-Bücklers corneal dystrophy.

\section{Immunohistochemistry}

Abnormal deposits react with antibodies to transforming growth factor beta-induced protein (keratoepithelin).

\section{Confocal Microscopy}

Abnormal hyperreflective opacities in snowflake and trapezoidal shapes.

\section{Category}

1.

\section{BIBLIOGRAPHY}

- Bücklers M. Die erblichen Hornhautdystrophien. Klin Monatsbl Augenheilkd. 1938;Beiheft 3:1-135.

- Eiberg E, Møller HU, Berendt I, et al. Assignment of granular corneal dystrophy Groenouw type I (CDGG1) to chromosome 5q. Eur J Hum Genet. 1994;2:132-138. 
- Groenouw A. Knötchenförmige Hornhauttrübungen (Noduli corneae). Arch Augenheilkd. 1890;21:281-289.

- Jones ST, Zimmerman LE. Histopathologic differentiation of granular, macular and lattice dystrophies of the cornea. Am J Ophthalmol. 1961;51:394-410.

- Matsuo N, Fujiwara H, Ofuchi Y. Electron and light microscopic observations of a case of Groenouw's nodular corneal dystrophy. Folia Ophthalmol Jpn. 1967; 18:436-447.

- Møller HU. Granular corneal dystrophy Groenouw type I. Clinical and genetic aspects. Acta Ophthalmol. 1991;69 (suppl 198):1-40.

- Munier FL, Korvatska E, Djemaï A, et al. Kerato-epithelin mutations in four 5q31-linked corneal dystrophies. Nat Genet. 1997;15:247-251.

- Seitz B, Behrens A, Langenbucher A, et al. Morphometric analysis of deposits in granular and lattice corneal dystrophy -histopathologic implications for phototherapeutic keratectomy. Cornea. 2004;23:380-385.

- Stone EM, Mathers WD, Rosenwasser GD, et al. Three autosomal dominant corneal dystrophies map to chromosome 5q. Nat Genet. 1994;6:47-51.

- Weidle EG, Lisch W. Die verschiedenen Trübungsformen der bröckeligen Hornhaut-dystrophie. Klin Monatsbl Augenheilkd. 1984;185:167-173.

- Wittebol-Post D, van der Want JJL, van Bijsterveld OP. Granular dystrophy of the cornea (Groenouw's type I). Ophthalmologica. 1987;195:169-177.

\section{Granular Corneal Dystrophy, type 2 (GCD2) MIM \#607541.}

\section{Former Alternative Names and Eponyms \\ Avellino dystrophy \\ Combined granular-lattice dystrophy}

For nearly a century, this entity was considered a mild GCD variant (Groenouw type I). Bücklers, as early as 1938 , described and depicted a large family with this phenotype. Fifty years later, Weidle published reporting the same patients and subdivided granular dystrophy according to subtle clinical differences. In 1988, Folberg et al. described the histopathology of both amyloid and hyaline deposits in such patients. In 1992, the clinical findings of these patients were published and termed Avellino corneal dystrophy. The term Avellino (the district of Italy where the initial published pedigree originated) came into popular and published usage but is now considered obsolete because of the dystrophy's global occurrence. Others have used the term combined granular-lattice dystrophy although the amyloid component is typically only apparent by histopathology and does not resemble lattice lines.

\section{Inheritance}

Autosomal dominant.

\section{Genetic Locus}

$5 \mathrm{q} 31$.

140 | www.corneajrnl.com
Gene

Transforming growth factor beta-induced-TGFBI.

\section{Onset}

Homozygous patients have earlier onset with dystrophy diagnosed, as early as 3 years of age, compared with heterozygotes, who may be diagnosed as early as the age of 8 . Most GCD2 is diagnosed during teens or during early adulthood.

\section{Signs}

In heterozygote, initial signs are subtle superficial stromal tiny whitish dots (Fig. 13A), which typically develop small spokes or thorns. Some may be arranged linearly like a string of pearls. Later, all eyes show superficial whitish round patches that have moth-eaten centers so that they may even appear to be discoid or ringshaped. Most patients also develop spiky anterior to midstromal deposits that are star, icicle, or spider-shaped (Fig. 13B) and partially translucent in retroillumination (Fig. $13 \mathrm{Bb}$ ). Patients may also have entirely translucent short dash-like linear or dot-like deposits in the posterior stroma deep to the branching stromal opacities.

The short lines or dashes sometimes observed in GCD2 can be distinguished from lattice lines observed in classic LCD and most of its variants:

1. Dashes in GCD2 appear whiter, and lattice lines in LCD are more refractile.

2. Dashes in GCD2 rarely cross each other, while lattice lines in LCD characteristically intersect to result in the pathognomonic lattice configuration.

Consequent to epithelial erosions, spontaneous drop out of superficial granules results in clearing of the central zone of opacity, which also becomes thickened with recurrences. Ultimately, more superficial translucent flattened breadcrumb opacities coalesce in the sub-Bowman anterior stroma (Fig. 13C).

Phenotypic expressivity varies considerably with patients manifesting only a few white dots, and others showing deposits throughout the stroma. Patients with GCD2 have fewer stromal opacities than those with GCD1. Homozygote patients initially demonstrate numerous small dots in the superficial cornea in early childhood. By adulthood, there are larger, very dense irregularly shaped opacities in the superficial stroma that become deeper with time (Fig. 13D).

\section{Symptoms}

Vision decreases with age as the central visual axis becomes affected. Pain accompanies epithelial erosions.

\section{Course}

Slowly progressive.

Homozygotes demonstrate more rapid progression.

\section{Light Microscopy}

Corneal opacities extend from the basal epithelium to the deep stroma. There is deposition of both hyalin and amyloid and

Copyright (C) 2014 Wolters Kluwer Health, Inc. All rights reserved. 

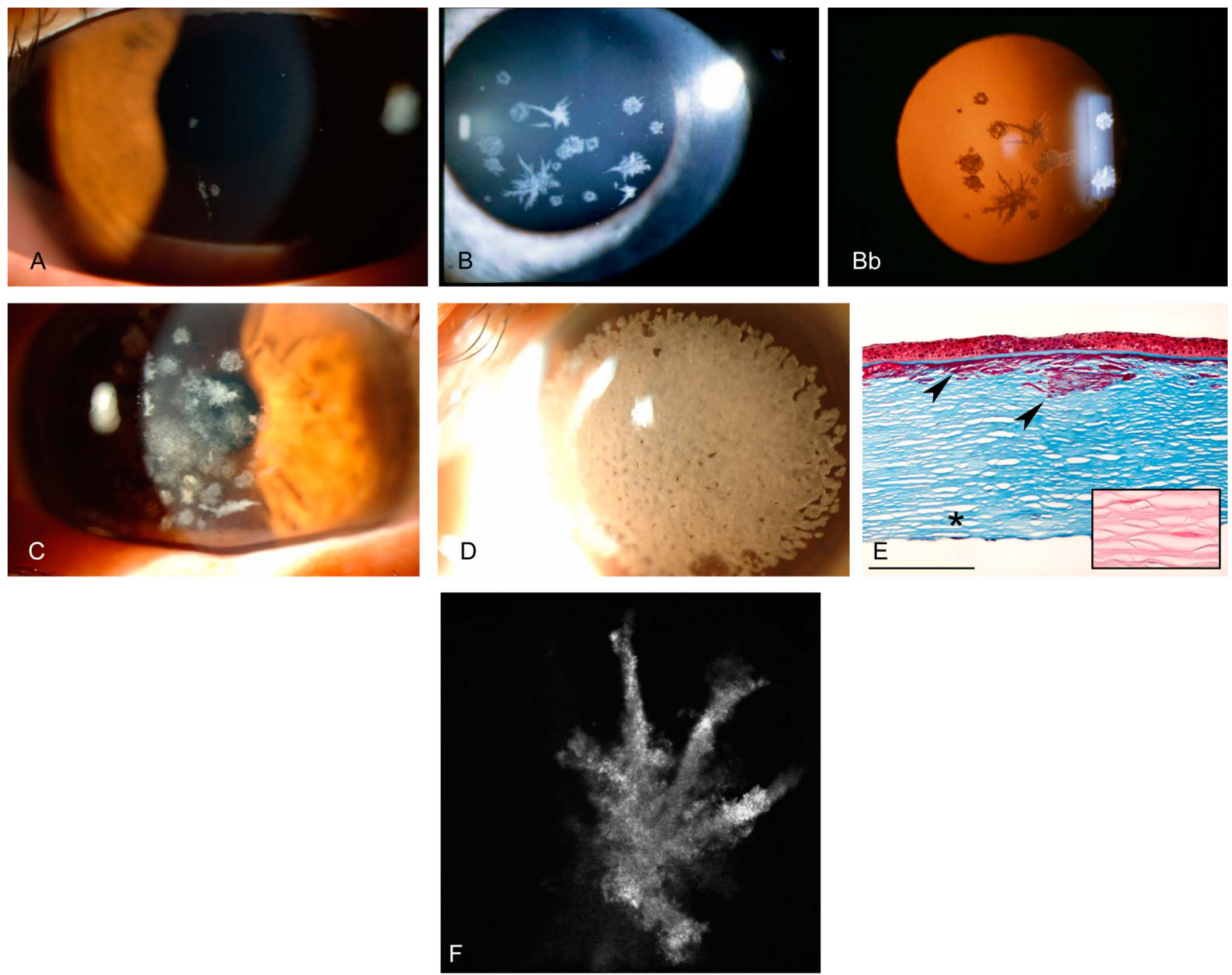

FIGURE 13. GCD, type 2 (GCD2). A, A 13-year-old with few white dots and genetic confirmation of GCD2. B, Direct and (Bb) retroillumination demonstrate branching, star-shaped, spiny, and ring-like deposits. C, Genetically confirmed GCD2 with superficial translucent flattened breadcrumb opacity beneath the Bowman layer. Denser icicles and disc-like and ring-like opacities. D, Genetically confirmed homozygote with denser and confluent opacities. E, Light microscopy-Masson trichrome stains sub-Bowman and anterior stromal keratohyalin deposits red (arrowheads). Note that the deeper stromal layers do not have keratohyalin granules (asterisk). In the deep stroma, small amyloid deposits stain with Congo red (inset), Arg124His TGFBI mutation (bar $=300$ and $200 \mu \mathrm{m}$ inset). $\mathrm{F}$, In vivo confocal microscopy shows abnormal hyperreflective stromal deposits with a snowflake or trapezoidal shape within the corneal stroma $(400 \times 400 \mu \mathrm{m})$. Figures $13 \mathrm{~B}$ from Figures $13 \mathrm{~B}$ in Weiss JS, Møller HU, Lisch W, et al. The IC3D classification of the corneal dystrophies. Cornea. 2008;27(suppl 2):S1-S4.

individual opacities stain with Masson trichrome and/or Congo red (Fig. 13E). Homozygotes demonstrate more severe findings.

\section{Transmission Electron Microscopy}

Anterior stromal rod-shaped very electron-dense deposits are similar to those noted in GCD1. On higher magnification, the rod-shaped deposit is composed of extracellular masses of fine, electron-dense, highly aligned fibrils. Enlarged keratocytes of heterozygous corneal tissue demonstrate intracellular organelles while details of the intracellular organelles are barely discernible in normal cell cytoplasm. In heterozygous tissue, keratocytes contain many dilated or degenerative mitochondria and vesicles containing amorphous material.

An extremely common ultrastructural finding is the presence of randomly aligned fibrils of amyloid (see LCD template).

Homozygotes demonstrate more severe findings.

\section{Confocal Microscopy}

Reflective breadcrumb-like round deposits with welldelineated borders or highly reflective irregular trapezoidal deposits are present in the anterior stroma (similar to GCD1). 
Linear and branching deposits with changing reflectivity (Fig. 13F) are observed (similar to those in LCD).

\section{Category}

1.

Note: Injury to the central cornea results in exacerbation of this corneal dystrophy with accelerated opacification. Hence, laser in situ keratomileusis, photorefractive keratectomy, and laser assisted in situ epithelial keratomileusis are strongly contraindicated in this dystrophy. Usually, GCD2 exacerbated more after laser in situ keratomileusis than after laser assisted in situ epithelial keratomileusis or photorefractive keratectomy.

In heterozygous GCD2 patients, superficial phototherapeutic keratectomy (PTK) may be judiciously used to reduce visually significant anterior stromal haze, recognizing that repeated PTK treatments and possibly keratoplasty may be eventually required. In homozygous GCD2, PTK results in more rapid recurrence than in heterozygous GCD2. However, when intervention is indicated, repeated PTK can be used in an effort to postpone more definitive intervention by keratoplasty.

\section{BIBLIOGRAPHY}

- Banning CS, Kim WC, Randleman JB, et al. Exacerbation of Avellino corneal dystrophy after LASIK in North America. Cornea. 2006;25:482-484.

- Bücklers M. Die erblichen Hornhautdystrophie. Klin Monatsbl Augenheilkd. 1938;3:1-135.

- Folberg R, Alfonso E, Croxatto JO, et al. Clinically atypical granular corneal dystrophy with pathologic features of lattice-like amyloid deposits: a study of three families. Ophthalmology. 1988;95:46-51.

- Han KE, Choi SI, Chung WS, et al. Extremely varied phenotypes in granular corneal dystrophy type 2 heterozygotes. Mol Vis. 2012;18:1755-1762.

- Han KE, Chung WS, Kim T, et al. Changes of clinical manifestation of granular corneal deposits because of recurrent corneal erosion in granular corneal dystrophy types 1 and 2. Cornea. 2013;32:e113-e120.

- Holland EJ, Daya SM, Stone EM, et al. Avellino corneal dystrophy. Clinical manifestations and natural history. Ophthalmology. 1992;99:1564-1568.

- Hong JP, Kim TI, Chung JL, et al. Analysis of deposit depth and morphology in granular corneal dystrophy type 2 using Fourier domain optical coherence tomography. Cornea. 2011;30:729-738.

- Jones ST, Zimmerman LE. Histopathologic differentiation of granular, macular and lattice dystrophies of the cornea. Am J Ophthalmol. 1961;51:394-410.

- Jun RM, Tchah H, Kim TI, et al. Avellino corneal dystrophy after LASIK. Ophthalmology. 2004;111:463-468.

- Kim TI, Kim T, Kim SW, et al. Comparison of corneal deposits after LASIK and PRK in eyes with granular corneal dystrophy type II. J Refract Surg. 2008;24:392395.

- Kim TI. Kim H, Lee DJ, et al. Altered mitochondrial function in type 2 granular corneal dystrophy. Am J Pathol. 2011;179:684-692.

\section{2 | www.corneajrnl.com}

- Lee JH, Chung SH, Stulting RD, et al. Effects of corneal neovascularization on the manifestations of Avellino corneal dystrophy (granular corneal dystrophy type II) Cornea . 2006;25:914-918.

- Lee JH, Stulting RD, Lee DH, et al. Exacerbation of granular corneal dystrophy type II (Avellino corneal dystrophy) after LASEK. J Refract Surg. 2008;24:39-45.

- Matsuo N, Fujiwara H, Ofuchi Y. Electron and light microscopic observations of a case of Groenouw's nodular corneal dystrophy. Folia Ophthalmol Jpn. 1967;18:436447.

- Moon JW, Kim SW, Kim T, et al. Homozygous granular corneal dystrophy type II (Avellino corneal dystrophy): natural history and progression after treatment. Cornea. 2007;26:1095-1100.

- Munier FL, Korvatska E, Djemaï A, et al. Kerato-epithelin mutations in four 5q31-linked corneal dystrophies. Nat Genet. 1997;15:247-251.

- Roh MI, Chung SH, Stulting RD, et al. Preserved peripheral corneal clarity after surgical trauma in patients with Avellino corneal dystrophy. Cornea. 2006;25:497-498.

- Roh MI, Grossniklaus HE, Chung SH, et al. Avellino corneal dystrophy exacerbated after LASIK: scanning electron microscopic findings. Cornea. 2006;25:306-311.

- Weidle EG. Granular corneal dystrophy: two variants. In: Ferraz de Olivera LN, ed. Ophthalmology Today. Amsterdam, The Netherlands: Elsevier; 1988:617-619.

\section{STROMAL DYSTROPHIES}

Macular Corneal Dystrophy (MCD) MIM \#217800.

\section{Former Alternative Names and Eponyms}

Groenouw corneal dystrophy type II.

Fehr speckled dystrophy.

\section{Inheritance}

Autosomal recessive.

\section{Genetic Locus}

$16 \mathrm{q} 22$.

Gene

Carbohydrate sulfotransferase 6 gene-CHST6.

Onset

Childhood.

\section{Signs}

Initially, central, superficial, irregular whitish fleck-like opacities develop, which give the condition its name (Fig. 14A); and unlike GCD, these flecks involve the limbus and the deep stroma down to Descemet membrane (Fig. 14B). Simultaneously, a progressive diffuse haze develops, which involves the entire corneal stroma (Fig. 14C). The epithelium remains smooth, but occasionally develops corneal erosions.

The cornea is much thinner than normal. As the disorder progresses, Descemet membrane becomes grayer

Copyright (๑) 2014 Wolters Kluwer Health, Inc. All rights reserved. 

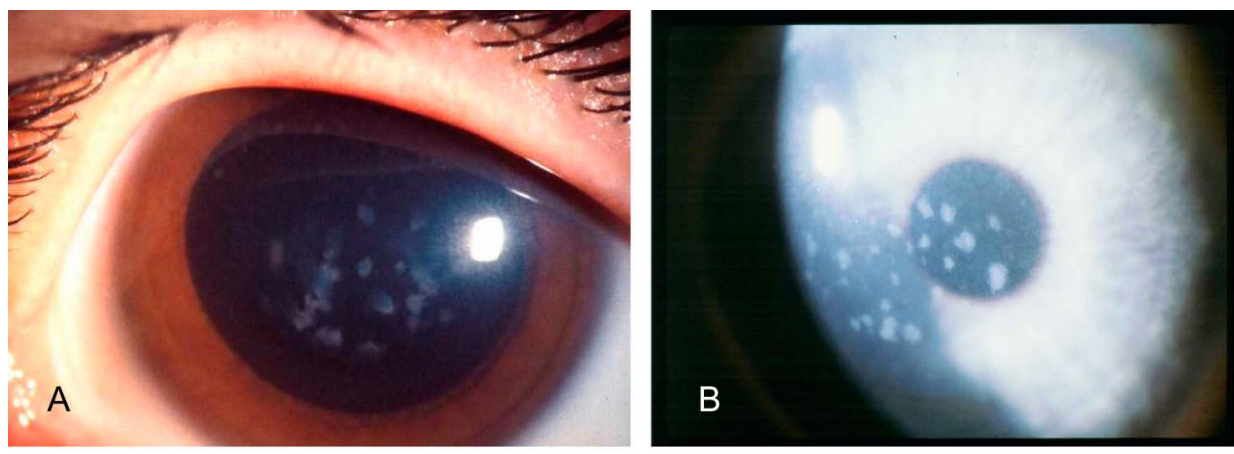

FIGURE 14. MCD. A, Early stage with few central macular opacities. B, Spreading of the deposits to the limbus and to the deep stroma down to Descemet membrane. C, More diffuse opacities and haze involving the entire stroma in an individual with type $2 \mathrm{MCD}$ associated with the heterozygous c.1519T $>C(p($ Leu276Pro)) mutation in CHST6. D, Light microscopy-intracellular and extracellular accumulation of GAGs at all levels of stroma and corneal endothelium. Subepithelial fibrous tissue also contains GAGs. Colloidal iron, $\times 20$. $E$, In vivo confocal microscopy image $(400 \times 400 \mu \mathrm{m})$ showing hyperreflective abnormal areas within the stroma. Some dark striae could be observed within the hyperreflective material. Figure 14A from Figure 14A in Weiss JS, Møller HU, Lisch $W$, et al. The IC3D classification of the corneal dystrophies. Cornea. 2008;27(suppl 2):S1-S42.
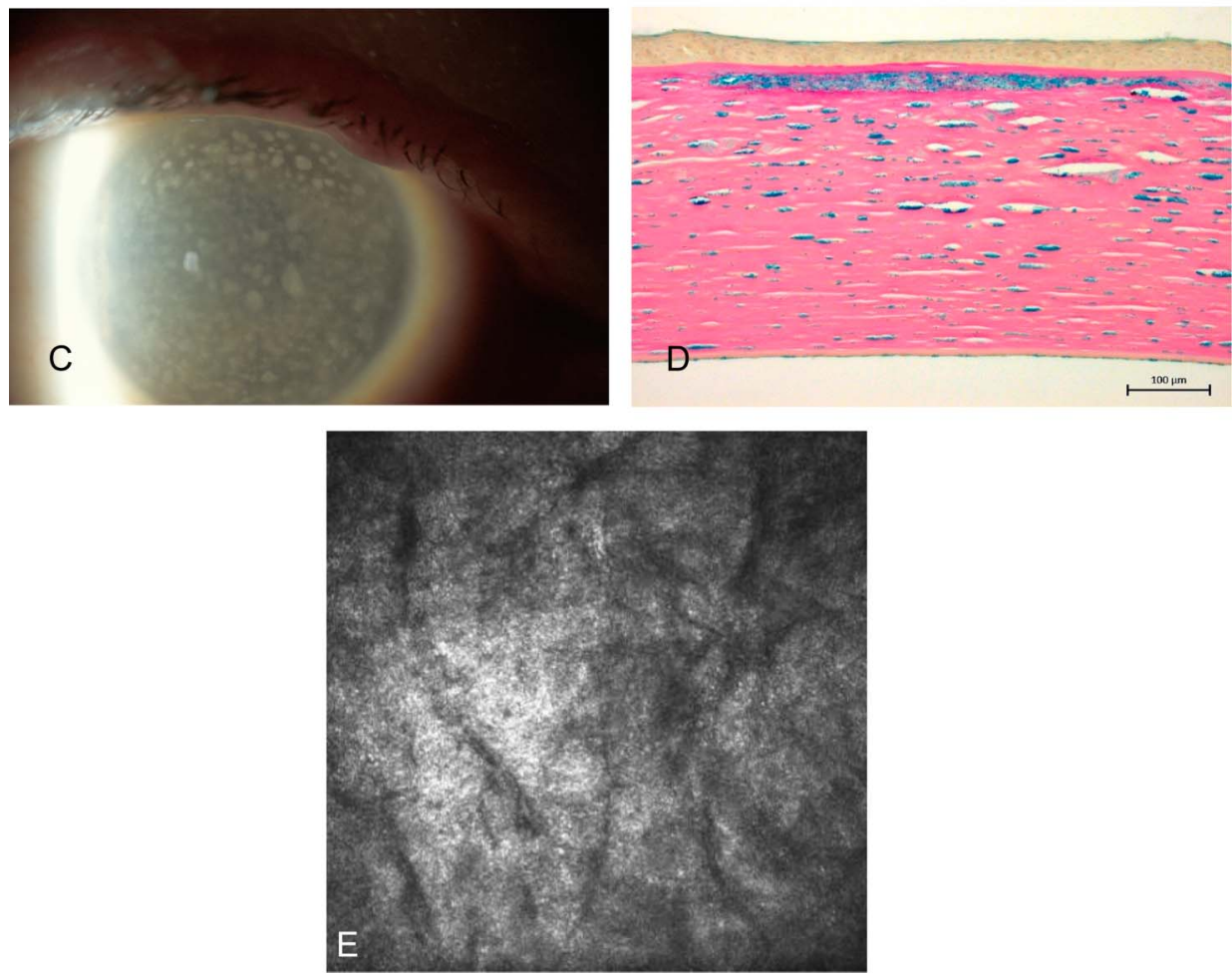

and develops guttate excrescences although endothelial decompensation rarely occurs.

\section{Symptoms}

Severe visual impairment occurs between 10 and 30 years of age. Corneal sensitivity is reduced. Photophobia and painful recurrent erosions can rarely occur.

\section{Course}

Slowly progressive.

\section{Light Microscopy}

Breaks in the Bowman layer. Glycosaminoglycans (GAGs) diffusely accumulate intracellularly and extracellularly throughout the corneal stroma. Unique to stromal dystrophies, Descemet membrane and endothelium are primarily involved, as evidenced by Descemet thickening and guttata plus endothelial staining with Hale colloidal iron or Alcian blue (Fig. 14D).

\section{Transmission Electron Microscopy}

Keratocytes and endothelial cells stain positively for GAGs and contain vacuoles and lamellar bodies. The extracellular matrix contains focal and diffuse fibrillogranular GAGs.

\section{Optical Coherence Microscopy}

Time-domain and spectral domain OCT show hyperreflectivity throughout the corneal stroma corresponding to diffuse corneal clouding together with diffuse hyperreflective opacities especially in the Bowman layer. Spectral domain OCT is able to visualize early changes in the Bowman layer, while time-domain OCT reveals hyperreflective accumulations in the anterior corneal stroma and peripheral posterior cornea stroma.

\section{Confocal Microscopy}

Blurred limited accumulations of highly reflective deposits are seen in the basal epithelium and anterior and 
mid stroma (Fig. 14E). Some of these may have dark striaelike images. Normal keratocytes may not be seen.

\section{Additional Findings}

Although clinically indistinguishable, 3 variants of MCD are distinguished on the basis of immunoreactivity of specific sulfated epitopes of antigenic keratan sulfates $(\mathrm{AgKS})$ in the cornea and the serum.

- MCD type I: No AgKS reactivity in the cornea or in the serum.

- MCD type IA: Keratocytes manifest AgKS reactivity, but the extracellular material does not. Serum lacks AgKS.

- MCD type II: All the abnormal deposits react positively with AgKS, and the serum has normal or lower levels of AgKS.

Note: Electron microscopic corneal findings in systemic mucopolysaccharidoses are similar to findings that are seen in macular dystrophy. However, on clinical examination and light microscopy, cornea findings demonstrate more diffuse and earlier opacification without flecks in mucopolysaccharidoses that show corneal involvement (especially Hurler, Hurler-Scheie, and Maroteaux-Lamy types). The decisive phenotypical difference between MCD and the mucopolysaccharidoses are the flecks, which appear in MCD.

\section{Category}

1.

Note: A single case of uniparental (maternal) isodisomy has been reported that represents the first evaluation in association with a corneal dystrophy. Because MCD is recessively inherited, 2 alleles need to carry a pathogenic mutation. In this case, the father has 2 normal CHST6 genes, and the mother has 1 normal and 1 mutated CHST6 gene. Because the child has 2 identical CHST6 gene mutations (homozygous), and nonpaternity was excluded, the only explanation is a duplication of the chromosome or locus carrying the mutated CHST6 from the mother.

\section{BIBLIOGRAPHY}

- Akama TO, Nishida K, Nakayama J, et al. Macular corneal dystrophy type I and type II are caused by distinct mutations in a new sulphotransferase gene. Nat Genet. 2000;26:237241.

- Fehr O. Ueber familiäre, fleckige Hornhaut-Entartung. Zentralbl Prakt Augenheilkd. 1904;28:1-11.

- Groenouw A. Knötchenförmige Hornhauttrübungen (Noduli corneae). Arch Augenheilk. 1890;21:237-241.

- Klintworth GK, Smith CF, Bowling BL. CHST6 mutations in North American subjects with macular corneal dystrophy: a comprehensive molecular genetic review. Mol Vis. 2006;12:159-176.

- Klintworth GK, Vogel FS. Macular corneal dystrophy: an inherited acid mucopolysaccharide storage disease of the corneal fibroblast. Am J Pathol. 1964;45:565-586.

- Klintworth GK. Research into the pathogenesis of macular corneal dystrophy. Trans Ophthalmol Soc U K. 1980;100: 186-194.

144 | www.corneajrnl.com
- Nowinska AK, Wylegala E, Teper S, et al. Phenotype and genotype analysis in patients with macular corneal dystrophy. Br J Ophthalmol. 2014;98:1514-1521.

- Snip RC, Kenyon KR, Green WR. Macular corneal dystrophy: ultrastructural pathology of corneal endothelium and Descemet's membrane. Invest Ophthalmol. 1973;12:88-97.

- Vance JM, Jonasson F, Lennon F, et al. Linkage of a gene for macular corneal dystrophy to chromosome 16. Am J Hum Genet. 1996;58:757-762.

- Yellore VS, Sonmez B, Chen MC, et al. An unusual presentation of macular corneal dystrophy associated with uniparental isodisomy and a novel Leu173Pro mutation. Ophthalmic Genet. 2007;28:169-174.

\section{Schnyder Corneal Dystrophy (SCD) MIM \#21800.}

\section{Former Alternative Names and Eponyms}

Schnyder crystalline corneal dystrophy (SCCD) Schnyder crystalline dystrophy sine crystals. Hereditary crystalline stromal dystrophy of Schnyder. Crystalline stromal dystrophy. Central stromal crystalline corneal dystrophy. Corneal crystalline dystrophy of Schnyder. Schnyder corneal crystalline dystrophy.

\section{Inheritance}

Autosomal dominant.

\section{Genetic Locus \\ $1 \mathrm{p} 36$.}

Gene

UbiA prenyltransferase domain containing 1-UBIAD1.

\section{Onset}

Maybe as early as childhood, but diagnosis usually made by the second or third decade. Diagnosis may be further delayed in patients who have the acrystalline form of the disease.

\section{Signs}

Corneal changes are predictable on the basis of age. Patients 23 years or younger have ring- or disc-like central corneal opacity and/or central crowded commashaped subepithelial crystals (Figs. 15A, B). Between 23 and 38 years of age, arcus lipoides is also noted (Fig. 15 C). After the age of 38, midperipheral panstromal haze also develops, causing the entire cornea to appear hazy (Figs. 15D-F). Despite the former (now obsolete) name of SCCD, only $50 \%$ of patients demonstrate corneal crystals. Crystals may be unilateral, may rarely regress, and can occur late in the disease.

\section{Symptoms}

Visual acuity decreases, and complaints of glare increase with age. Although scotopic vision may be

Copyright (c) 2014 Wolters Kluwer Health, Inc. All rights reserved. 

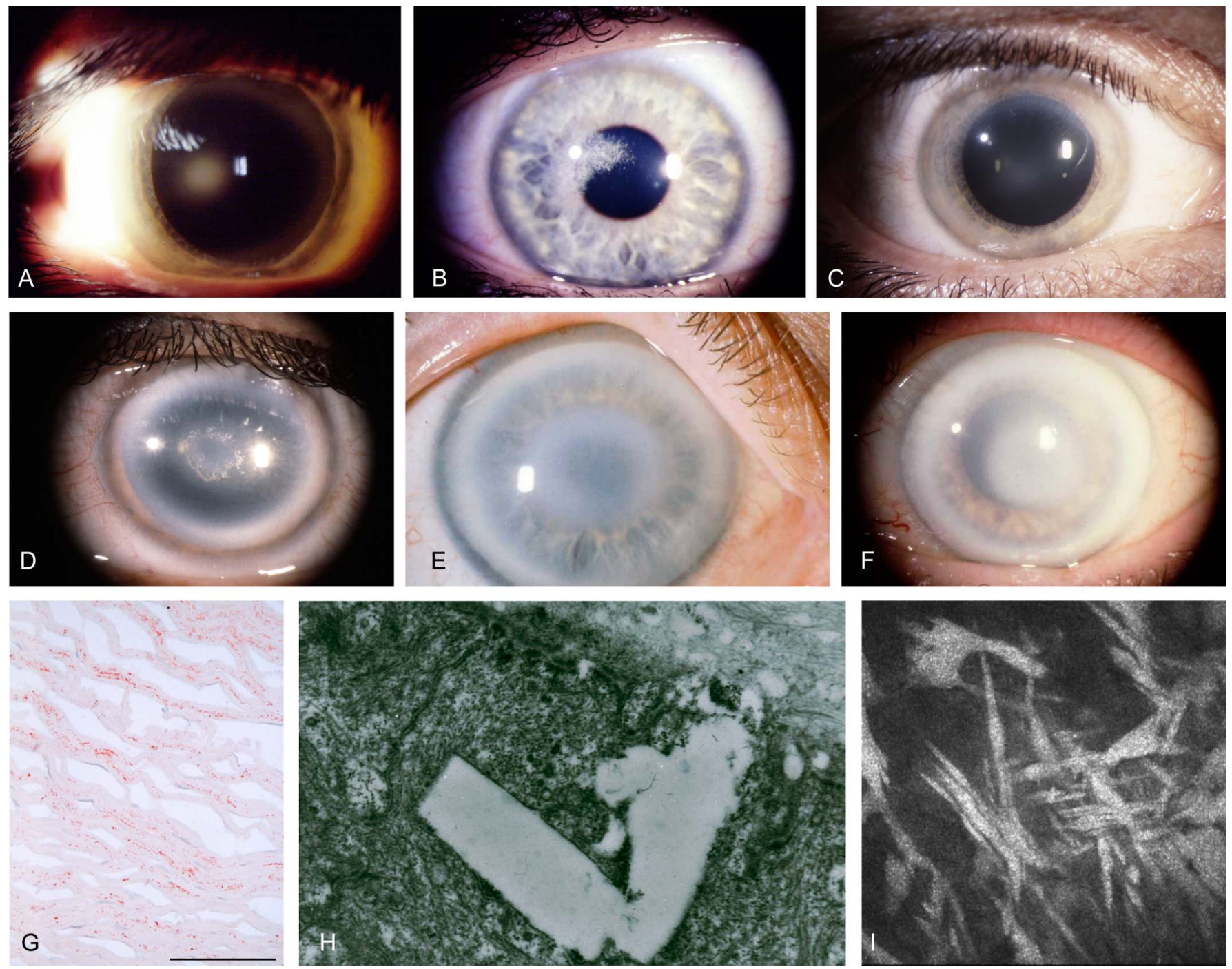

FIGURE 15. SCD. A, Central stromal opacity in early SCD without crystals in a patient with mutation in UBIAD1. B, Early subepithelial central crystalline deposit in a patient with mutation in UBIAD1. C, Central corneal opacity with arcus lipoides. D, Central corneal opacity, subepithelial crystalline ring, mid peripheral haze, and arcus lipoides. E, Noncrystalline central diffuse opacity pattern with clearer area centrally, mid peripheral haze and prominent arcus lipoides in a 39-year-old SCD patient with UBIAD1 mutation. F, Noncrystalline disc-like central opacity, mid peripheral haze and prominent arcus lipoides in a 72-year-old patient with SCD with UBIAD1 mutation. G, Light microscopy-Oil Red O stains innumerable tiny lipid droplets within the corneal stroma in a frozen section that has not undergone processing for paraffin embedding, which would dissolve the lipids and make the staining negative, bar $=100 \mu \mathrm{m} . \mathrm{H}$, Electron microscopy: empty crystalline space within a basal cell representing cholesterol deposit dissolved during dehydration stage of embedding process $\times 10,000$ (SCD with crystals). I, In vivo confocal microscopy $(400 \times 400 \mu \mathrm{m})$ shows abnormal hyperreflective homogeneous spindle-shaped deposits within the anterior stroma (SCD with crystals). Figure 15B and Figure 15C from Figure 15B and 15A in Weiss JS, Møller HU, Lisch W, et al. The IC3D classification of the corneal dystrophies. Cornea. 2008;27(suppl 2):S1-S42.

remarkably good (considering the slit-lamp appearance), photopic vision may be disproportionately decreased. Corneal sensation decreases with age. Both affected and unaffected members of the pedigrees may have hyperlipoproteinemia (type IIa, III, or IV).

\section{Course}

Although slowly progressive, the majority of patients older than 50 years have severe reduction of photopic vision.

\section{Light Microscopy}

Abnormal deposition of intracellular and extracellular esterified and unesterified phospholipids and cholesterol in basal epithelial cells, the Bowman layer, and stroma. As organic solvents and resins can dissolve lipids, staining for lipids [such as Oil Red O (Fig. 15G) or Sudan black] are facilitated by submitting fresh tissue for pathology, ensuring appropriate fixation for special stains. In addition, there are 
single published reports of SCD corneas with positive Congo red staining, suggesting secondary amyloid deposition and another with the addition of Alcian blue staining suggesting secondary deposition of GAGs.

\section{Transmission Electron Microscopy}

Abnormal accumulation of intracellular and extracellular esterified and unesterified phospholipids and cholesterol are deposited in the epithelium (Fig. 15H) in the Bowman layer and throughout the stroma. Endothelial lipid has rarely been reported.

\section{Confocal Microscopy}

Intracellular and extracellular highly reflective deposits may lead to eventual disruption of the basal epithelial/ subepithelial nerve plexus (Fig. 15I).

\section{Category}

1.

Note: Although SCCD has been the more commonly used name for this entity, this has caused diagnostic confusion as only $50 \%$ of patients exhibit corneal crystals. Consequently, SCD should be the preferred name. If the ophthalmologist does not suspect SCD when performing keratoplasty, the opportunity to perform lipid stains may be lost if the corneal specimen is not preserved correctly (as specified above).

\section{BIBLIOGRAPHY}

- Delleman JW, Winkelman JE. Degeneratio corneae cristallinea hereditaria. A clinical, genetical and histological study. Ophthalmologica. 1968;155:409-426.

- Eiferman RA, Rodrigues MM, Laibson PR, et al. Schnyder's crystalline dystrophy associated with amyloid deposition. Metab Ophthalmol. 1979;3:15

- Gaynor PM, Zhang WY, Weiss JS, et al. Accumulation of HDL apolipoproteins accompanies abnormal cholesterol accumulation in Schnyder's corneal dystrophy. Arterioscler Thromb Vasc Biol. 1996;16:993-999.

- Lisch W, Weidle EG, Lisch C, et al. Schnyder's dystrophy. Progression and metabolism. Ophthalmic Paediatr Genet. 1986;7:45-56.

- Orr A, Sube MP, Marcadier, et al. Mutations in the UBIADI gene encoding a potential prenyltransferase are causal for Schnyder crystalline corneal dystrophy. PLoS One. 2007;2: e685.

- Pameijer JK. Über eine fremdartige familiäre oberflächliche Hornhaut-Veraenderung. Klin Monatsbl Augenheilkd. 1935;95:516-517.

- Schnyder WF. Mitteilung über einen neuen Typus von familiärer Hornhauterkrankung. Schweiz Med Wschr. 1929;10:559-571.

- Schnyder WF. Scheibenförmige Kristalleinlagerungen in der Hornhautmitte als Erbleiden. KIin Monatsbl Augenheilkd. 1939;103:494-502.

- Van Went JM, Wibaut F. En zeldzame erfelijke hoornvliessandoening. Niederl Tijdschr Geneesk. 1924;68:29962997.

\section{6 | www.corneajrnl.com}

- Vesaluoma MH, Linna TU, Sankila EM, et al. In vivo confocal microscopy of a family with Schnyder crystalline corneal dystrophy. Ophthalmology. 1999;106:944-951.

- Weiss JS, Khemichian AJ. Differential diagnosis of Schnyder corneal dystrophy. Dev Ophthalmol. 2011;48:67-96.

- Weiss JS, Kruth HS, Kuivaniemi H, et al. Mutations in the UBIAD1 gene on chromosome short arm 1, region 36 cause Schnyder crystalline corneal dystrophy. Invest Ophthalmol Vis Sci. 2007;48:5007-5012.

- Weiss JS, Rodrigues MM, Kruth HS, et al. Panstromal Schnyder's corneal dystrophy. Ultrastructural and histochemical studies. Ophthalmology. 1992;99:1072-1081.

- Weiss JS. Schnyder crystalline dystrophy sine crystals. Recommendation for a revision of nomenclature. Ophthalmology. 1996;103:465-473.

- Weiss JS. Schnyder's dystrophy of the cornea. A SwedeFinn connection. Cornea. 1992;11:93-101.

- Weiss JS. Visual morbidity in thirty-four families with Schnyder's corneal dystrophy. Trans Am Soc Ophthamol. 2007;105:1-33.

\section{Congenital Stromal Corneal Dystrophy (CSCD) MIM \#610048.}

\section{Former Alternative Names and Eponyms}

Congenital hereditary stromal dystrophy.

\section{Inheritance}

Autosomal dominant.

\section{Genetic Locus}

$12 \mathrm{q} 21.33$

\section{Gene}

Decorin, $D C N$.

Onset

Congenital.

\section{Signs}

Diffuse, bilateral corneal clouding with flake-like whitish stromal opacities throughout the stroma (Fig. 16A). The changes are equally pronounced in all areas of the cornea. The cornea surface is normal and without fluorescein staining or vascularization. Pachymetry demonstrates increased stromal thickness.

\section{Symptoms}

Moderate to severe visual loss. Photophobia occurs in a minority of patients.

\section{Course}

Nonprogressive or slowly progressive.

\section{Light Microscopy}

The stromal lamellae are irregularly separated and may contain amorphous material (Fig. 16B).

Copyright (c) 2014 Wolters Kluwer Health, Inc. All rights reserved. 

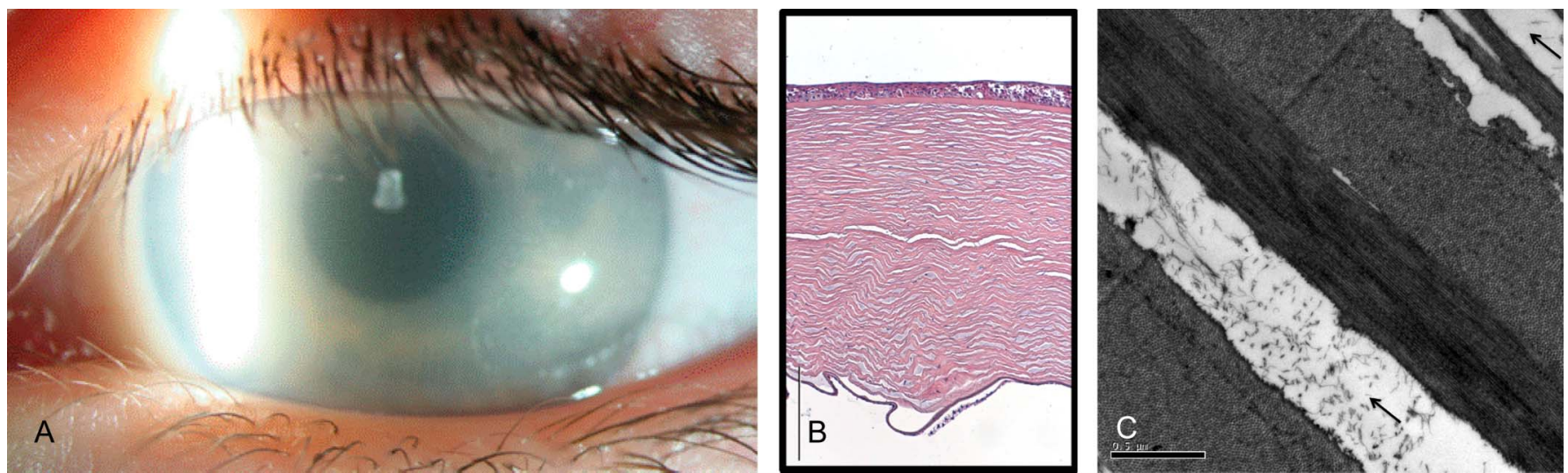

FIGURE 16. Congenital stromal corneal dystrophy. A, Diffuse clouding with flake-like opacities throughout the stroma in a 4-yearold patient with a DCN frameshift mutation (c.967delT). B, Light microscopy: the cornea is markedly thickened with stromal lamellae that are separated from each other in a regular manner with some areas of deposition, bar $=200 \mu \mathrm{m}$. C, Electron microscopy - apparently normal collagen lamellae are separated by areas of amorphous substance with small filaments (arrows) characteristic for the condition (original magnification $\times 20$ ).

\section{Transmission Electron Microscopy}

Amorphous areas consisting of thin filaments randomly arranged in an electron-lucent ground substance separate lamellae of normal appearance (Fig. 16C). The changes can be seen at all levels of the stroma. The abnormal layers are broader in the posterior stroma. The keratocytes and endothelium are normal, although absence of the anterior banded zone of Descemet membrane has been reported. Accumulation of decorin is found in the amorphous areas as determined by immunoelectron microscopy.

\section{Optical Coherence Tomography}

Increased corneal thickness. Diffuse higher reflectivity in the stroma.

\section{Confocal Microscopy}

Epithelial cells appear normal. Increased reflectivity from the anterior stroma prevents further studies.

\section{Category}

1.

\section{BIBLIOGRAPHY}

- Bredrup C, Knappskog PM, Majewski J, et al. Congenital stromal dystrophy of the cornea caused by a mutation in the decorin gene. Invest Ophthalmol Vis Sci. 2005;46:420-426.

- Bredrup C, Stang E, Bruland O, et al. Decorin accumulation contributes to the stromal opacities found in congenital stromal corneal dystrophy. Invest Ophthalmol Vis Sci. 2010;51:5578-5582.

- Desvignes P, Vigo. A propos d'un cas de dystrophie cornéenne parenchymateuse familiale à hérédité dominante. Bull Soc Ophtalmol Fr. 1955;4:220-225.

- Jing Y, Kumar RP, Zhu L, et al. Novel decorin mutation in a Chinese family with congenital stromal corneal dystrophy. Cornea. 2014;33:288-293.
- Kim JH, Ko JM, Lee I, et al. A novel mutation of the decorin gene identified in a Korean family with congenital hereditary stromal dystrophy. Cornea. 2011;30:1473-1477.

- Odland M. Dystrophia corneae parenchymatosa congenita. A clinical, morphological and histochemical examination. Acta Ophthalmol (Copenh). 1968;46:477-485.

- Pouliquen Y, Lacombe E, Schreinzer C, et al. La dystrophie congénitale héréditaire du stroma cornéen de Turpin. $J \mathrm{Fr}$ Ophtalmol. 1979;2:115-125.

- Turpin R, Tisserand M, Sérane J. Opacités cornéennes héréditaires et congénitales réparties sur trois générations et atteignant deux jumelles monozygotes. Arch Ophtalmol. 1939;3:109-111.

- Van Ginderdeuren R, De Vos R, Casteels I, et al. Report of a new family with dominant congenital hereditary stromal dystrophy of the cornea. Cornea. 2002;21:118-120.

- Witschel H, Fine BS, Grützner P, et al. Congenital hereditary stromal dystrophy of the cornea. Arch Ophthalmol. 1978;96:1043-1051.

\section{Fleck Corneal Dystrophy (FCD) \\ MIM \#121850.}

\section{Former Alternative Names and Eponyms}

François-Neetens speckled (mouchetée) corneal dystrophy.

\section{Inheritance}

Autosomal dominant.

\section{Gene Locus}

$$
2 \mathrm{q} 34 .
$$

\section{Gene}

Phosphoinositide kinase, FYVE finger containingPIKFYVE.

Note: Previously known as phosphatidylinositol-3phosphate/phosphatidylinositol 5-kinase type III-PIP5K3. 
FIGURE 17. Fleck corneal dystrophy. Dandruff-like opacities seen in 2 different patients throughout the stroma using: (A) broad oblique illumination, and (B) at varying depths in the slit-lamp photograph. Figures $17 A$ and $B$ from Figures $17 A$ and $B$ in Weiss JS, Møller HU, Lisch W, et al. The IC3D classification of the corneal dystrophies. Cornea. 2008;27(suppl 2):S1-S42.

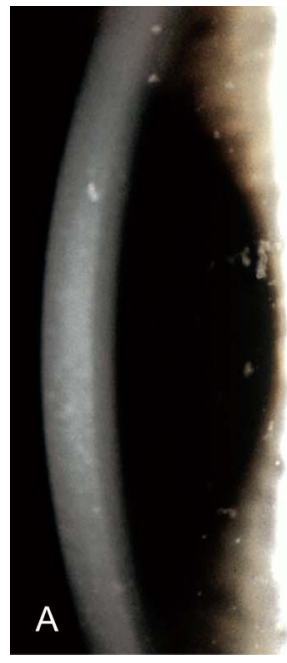

Onset

Congenital or first years of life.

\section{Signs}

Subtle but distinctive, small, translucent, discoid opacities or discrete, flat, gray-white, dandruff-like, and sometimes ring-shaped opacities scattered sparsely throughout any level of the otherwise clear stroma (Figs. 17A, B). Flecks may extend to the limbus and are best detected with slit beam or retroillumination. The epithelium, Bowman layer, Descemet membrane, and endothelium are not involved. Asymmetric or unilateral corneal involvement is possible.

\section{Symptoms}

Asymptomatic, occasionally slight photophobia or decreased corneal sensitivity.

\section{Course}

Nonprogressive.

\section{Light Microscopy}

Swollen, vacuolated keratocytes, which contain GAGs (staining with Alcian blue and colloidal iron) and complex lipids (demonstrated by Sudan black and Oil Red O).

\section{Transmission Electron Microscopy}

Some keratocytes show membrane-based inclusions with delicate granular material.

\section{Optical Coherence Tomography}

Flecks correspond to slightly brighter small areas.

\section{Confocal Microscopy}

Accumulation of hyperreflective 2 - to $18-\mu \mathrm{m}$ dot-like material in the normal-sized and enlarged stromal keratocyte nuclei. Inclusions in basal nerves and doughnut- or kidneyshaped $70-\times 110-\mu \mathrm{m}$ deposits have variably been reported.

\section{Category}

1.

148 | www.corneajrnl.com

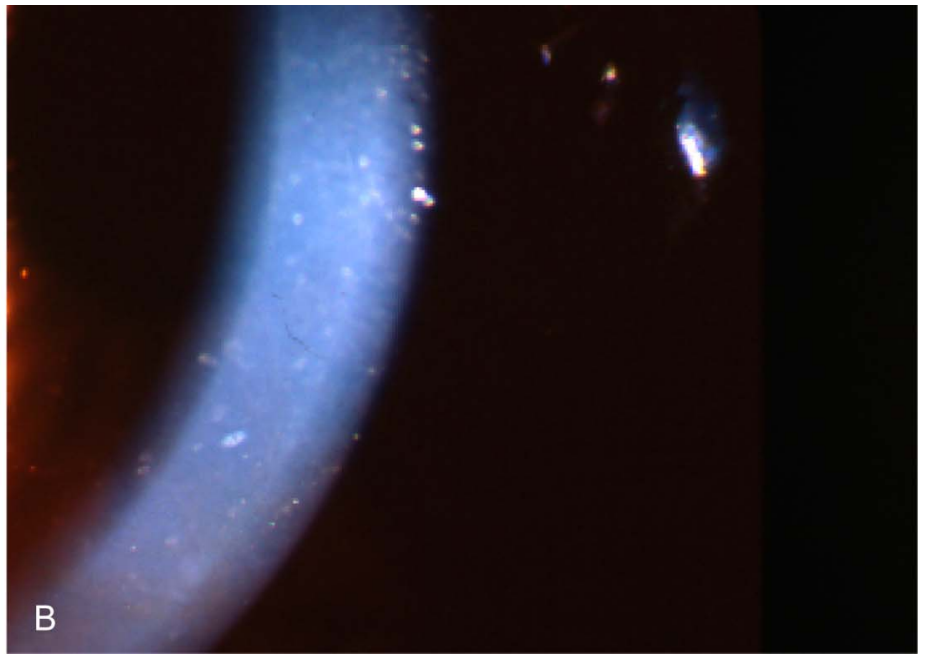

\section{BIBLIOGRAPHY}

- Assi A, Ebenezer N, Ficker L. Corneal fleck dystrophy in an English family. Br J Ophthalmol. 1999;83:1407-1408.

- Can E, Kan E, Akgün Hi. Clinical features and in vivo confocal microscopic imaging of fleck corneal dystrophy. Semin Ophthalmol. 2013;28:239-241.

- François J, Neetens A. Nouvelle dystrophie hérédofamiliale du parenchyme cornéen (hérédo-dystrophie mouchetée). Bull Soc Belge Ophtal. 1957;114:641-646.

- Gillespie F, Covelli B. Fleck (mouchetée) dystrophy of the cornea. Report of a family. South Med J. 1963;56:1265-1267.

- Holopainen JM, Moilanen JA, Tervo TM. In vivo confocal microscopy of fleck dystrophy and pre-Descemet membrane corneal dystrophy. Cornea. 2003;22:160-163.

- Jiao X, Munier FL, Schorderet DF, et al. Genetic linkage of François-Neetens fleck (mouchetée) corneal dystrophy to chromosome 2q35. Hum Genet. 2003;112:593-599.

-Kawasaki S, Yamasaki K, Nakagawa H, et al. A novel mutation (p.Glu1389AspfsX16) of the phosphoinositide kinase, FYVE finger containing gene found in a Japanese patient with fleck corneal dystrophy. Mol Vis. 2012;18:2954-2960.

- Li S, Tiab L, Jiao X, et al. Mutations in PIP5K3 are associated with François-Neetens mouchetée fleck corneal dystrophy. Am J Hum Genet. 2005;77:54-63.

- Nicholson DH, Green WR, Cross HE, et al. A clinical and histopathological study of François-Neetens speckled corneal dystrophy. Am J Ophthalmol. 1977;83:554-560.

- Patten JT, Hyndiuk RA, Donaldson DD, et al. Fleck (mouchetée) dystrophy of the cornea. Ann Ophthalmol. 1976;8:25-32.

- Purcell JJ Jr, Krachmer JH, Weingeist TA. Fleck corneal dystrophy. Arch Ophthalmol. 1977;95:440-444.

\section{Posterior Amorphous Corneal \\ Dystrophy (PACD) \\ MIM \#612868.}

\section{Former Alternative Names and Eponyms}

Posterior amorphous stromal dystrophy.

Copyright (C) 2014 Wolters Kluwer Health, Inc. All rights reserved. 

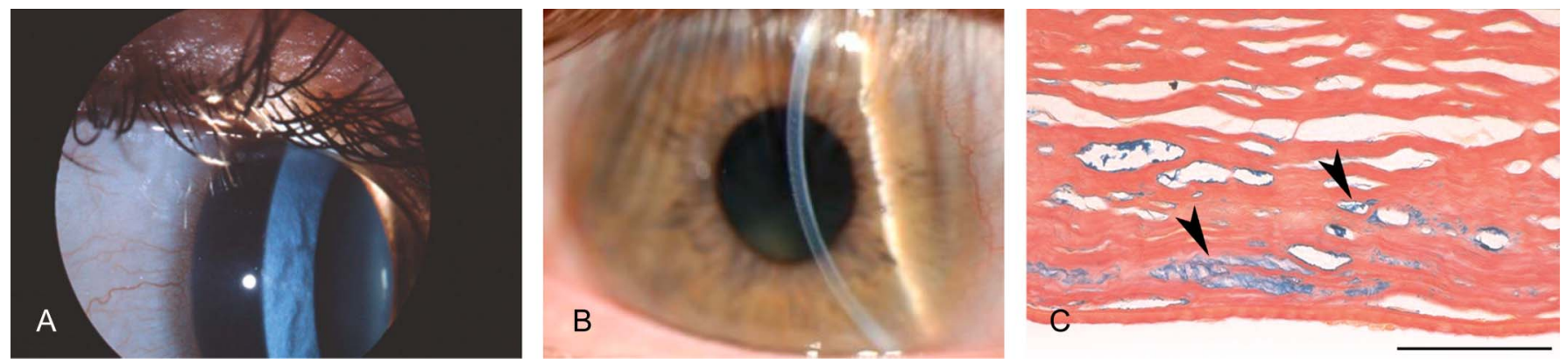

FIGURE 18. PACD. A, Central deep stromal/pre-Descemet opacity with some degree of peripheral extension interrupted by few clear bands in the midperipheral cornea. B, Slit beam demonstrates decreased corneal thickness and posterior stromal lamellar opacification. C, Light microscopy_extracellular colloidal iron stains positive material (arrowheads) in the posterior stroma, bar = $100 \mu \mathrm{m}$.

\section{Inheritance}

Autosomal dominant.

\section{Genetic Locus}

12q21.33.

\section{Gene}

Deletion of keratocan $(K E R A)$, lumican (LUM), decorin $(D C N)$, and epiphycan $(E P Y C)$.

\section{Onset}

Often occurs in the first decade of life and has been noted as early as 16 weeks, suggesting congenital origin.

\section{Signs}

PACD presents as diffuse gray-white sheet-like opacities that can involve any layer of the stroma but are most prominent posteriorly (Fig. 18A). The lesions can be centroperipheral, extending to the limbus, or peripheral, the latter with less pronounced findings and symptoms. Transparent stromal breaks are often present. Decreased corneal thickness (as thin as $380 \mu \mathrm{m}$ ) (Fig. 18B) and corneal flattening to less than 41 diopters with associated hyperopia are characteristic, particularly in the centroperipheral form. Descemet membrane and endothelium may be indented by the opacities, and focal endothelial abnormalities have been observed. Prominent Schwalbe line, fine iris processes, pupillary remnants, iridocorneal adhesions, corectopia, pseudopolycoria, and anterior stromal tags have been reported, particularly in patients with the centroperipheral pattern, but there is no association with glaucoma.

\section{Symptoms}

Visual acuity is mildly affected, usually better than 20/40.

\section{Course}

None or slowly progressive in the majority of cases.

\section{Light Microscopy}

Irregularity of the posterior stromal lamellae with colloidal iron staining, anterior to a thin Descemet membrane, and focal attenuation of endothelial cells (Fig. 18C).

\section{Transmission Electron Microscopy}

There are abnormally oriented collagen fibers and abnormal keratocytes with disorganization of the posterior stromal lamellae. A fibrillar layer resembling stromal collagen fibers interrupts Descemet membrane. These findings are not pathognomonic of this dystrophy and may be found in other abnormalities. In 1 patient with more pronounced changes, additional subepithelial deposits and a thick collagenous layer posterior to Descemet membrane were present.

\section{Confocal Microscopy}

Microfolds and a hyperreflective layer in the posterior stroma are present.

\section{Category}

1.

Note: The possible congenital onset, lack of progression and association with iris abnormalities raises the possibility of mesodermal dysgenesis rather than a true corneal dystrophy.

\section{BIBLIOGRAPHY}

- Aldave AJ, Rosenwasser GO, Yellore VS, et al. Linkage of posterior amorphous corneal dystrophy to chromosome $12 \mathrm{q} 21.33$ and exclusion of coding region mutations in KERA, LUM, DCN and EPYC. Invest Ophthalmol Vis Sci. 2010;51:4006-4012.

- Carpel EF, Sigelman RJ, Doughman DJ. Posterior amorphous corneal dystrophy. Am J Ophthalmol. 1977;83:629632.

- Dunn SP, Krachmer JH, Ching SS. New findings in posterior amorphous corneal dystrophy. Arch Ophthalmol. 1984;102:236-239.

- Erdem U, Muftuoglu O, Hurmeric V. In vivo confocal microscopy findings in a patient with posterior amorphous corneal dystrophy. Clin Experiment Ophthalmol. 2007;35:99-102.

- Johnson AT, Folberg R, Vrabec MP, et al. The pathology of posterior amorphous corneal dystrophy. Ophthalmology. 1990;97:104-109.

- Kim M, Frausto RF, Rosenwasser GOD, et al. Posterior amorphous corneal dystrophy is caused by a deletion of 


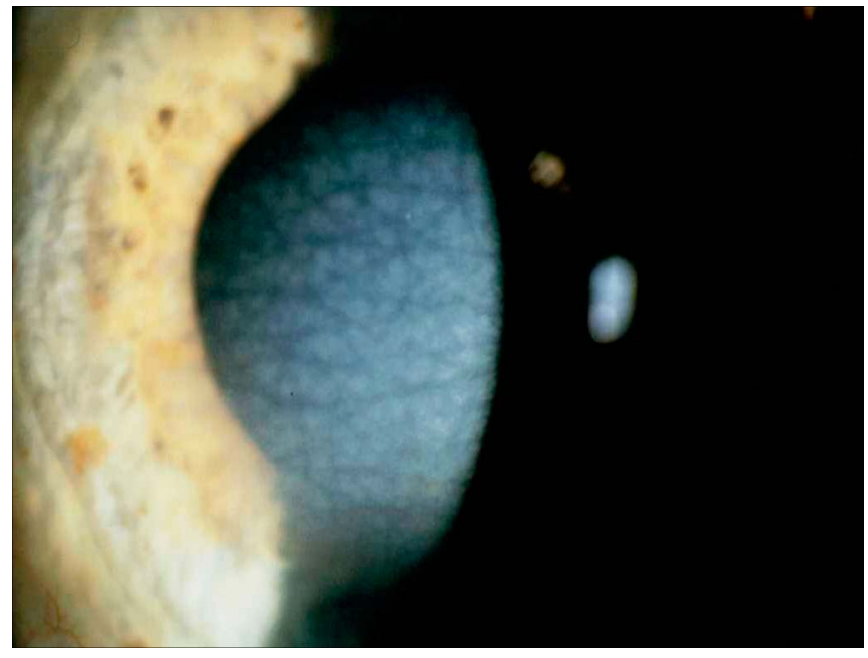

FIGURE 19. CCDF or posterior crocodile shagreen. No information about family history available. Axially distributed, polygonal gray-white stromal opacities separated by linear areas of clear cornea. Figure 19 from Figure 19A in Weiss JS, Møller HU, Lisch W, et al. The IC3D classification of the corneal dystrophies. Cornea. 2008;27(suppl 2):S1-S42.

small leucine-rich proteoglycans on chromosome 12. PLoS One. 2014;9:e95037.

- Moshegov CN, Hoe WK, Wiffen SJ, et al. Posterior amorphous corneal dystrophy. A new pedigree with phenotypic variation. Ophthalmology. 1996;103:474-478.

\section{Central Cloudy Dystrophy of François MIM \#217600.}

\section{Former Alternative Names and Eponyms None.}

\section{Inheritance}

Unknown. Autosomal dominant inheritance is occasionally reported. May be phenotypically indistinguishable from posterior crocodile shagreen, which is a corneal degeneration.

\section{Gene/Genetic Locus None.}

\section{Onset}

First decade (youngest affected patient was 8 years old).

\section{Signs}

Fortuitous finding of cloudy central polygonal or rounded stromal opacities that fade anteriorly and peripherally and are surrounded by clear tissue (Fig. 19). The changes are indistinguishable from Vogt posterior crocodile shagreen.

\section{Symptoms}

Mostly asymptomatic.

$150 \mid$ www.corneajrnl.com

\section{Course}

Nonprogressive.

\section{Light Microscopy}

No description in familial cases. Faint undulating appearance of the deep stroma and positive staining for GAGs.

\section{Transmission Electron Microscopy}

No description in familial cases, therefore published pathology could represent posterior crocodile shagreen. Extracellular vacuoles, some containing fibrillogranular material and electron-dense deposits. Endothelial vacuoles with fibrillogranular material and a sawtoothed lamellar pattern have also been reported.

\section{Confocal Microscopy}

No description in familial cases, therefore published confocal microscopy could represent posterior crocodile shagreen. In 2 unrelated patients, there were small highly refractile granules and deposits in the anterior stroma. Multiple dark striae in the extracellular matrix with increased intensity in the deep posterior stroma adjacent to the endothelium.

\section{Category}

4.

Note: Many of the publications referenced did not provide documentation that the corneal disease was familial. Consequently, it is entirely possible that these cases reported as CCDF might actually be posterior crocodile shagreen.

\section{BIBLIOGRAPHY}

- Bramsen T, Ehlers N, Baggesen LH. Central cloudy corneal dystrophy of François. Acta Ophthalmol (Copenh). 1976;54:221-226.

- François J. Une nouvelle dystrophie hérédo-familiale de la cornée. J Genet Hum. 1956;5:189-196.

- Kobayashi A, Sugiyama K, Huang AJ. In vivo confocal microscopy in patients with central cloudy dystrophy of François. Arch Ophthalmol. 2004;122:1676-1679.

- Meyer JC, Quantock AJ, Thonar EJ, et al. Characterization of a central corneal cloudiness sharing features of posterior crocodile shagreen and central cloudy dystrophy of François. Cornea. 1996;15:347-354.

- Strachan IM. Cloudy central corneal dystrophy of François. Five cases in the same family. $\mathrm{Br} J$ Ophthalmol. 1969;53:192-194.

- Zaidi A, McLeod SD. Laser in situ keratomileusis in a patient with presumed central cloudy corneal dystrophy of François. Am J Ophthalmol. 2005;139:376-377.

\section{Pre-Descemet Corneal Dystrophy (PDCD)} MIM: none.

\section{Former Alternative Names and Eponyms None.}

Copyright (C) 2014 Wolters Kluwer Health, Inc. All rights reserved. 

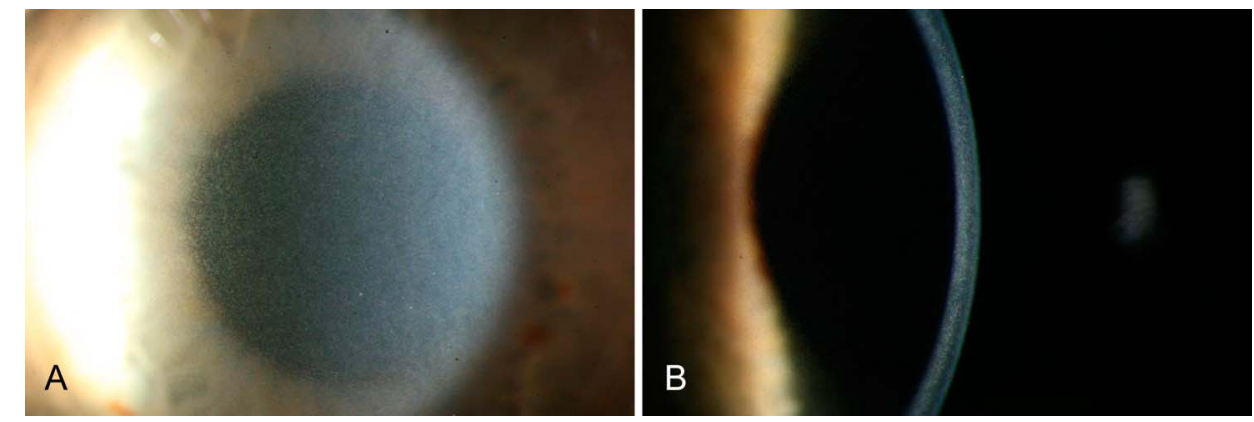

FIGURE 20. PDCD. A, With broadbeam illumination, punctate opacities anterior to Descemet membrane are apparent. B, Slit beam illumination of the same eye demonstrating punctate opacities anterior to Descemet membrane.

\section{Inheritance}

Isolated pre-Descemet corneal dystrophy (PDCD) is neither a well-defined entity nor is it clearly a hereditary or degenerative disorder (cornea farinata). Although there is no definite pattern of inheritance, it has been described in families over 2 to 4 generations. The subtype punctiform and polychromatic PDCD has been reported to be AD in 1 pedigree and may represent a specific dystrophy. Similar deep corneal opacities are frequently seen in X-linked ichthyosis (MIM \#308100)

\section{Genetic Locus}

Isolated PDCD—Unknown

PDCD associated with X-linked ichthyosis-Xp22.31.

\section{Gene}

Isolated PDCD - Unknown

PDCD associated with X-linked ichthyosis-Steroid sulfatase $(S T S)$.

\section{Onset}

Usually after 30 years of age but has been found in children as young as 3 years (punctiform and polychromatic pre-Descemet dystrophy).

\section{Signs}

PDCD has several subgroups, many of which may represent sporadic, age-related degenerative and secondary changes. Focal, fine, polymorphic gray opacities that may be central, annular, or diffuse are located in the deep stroma immediately anterior to Descemet membrane (Figs. 20A, B). In the punctiform and polychromatic subtype, the changes are more uniform and polychromatic, and the cornea is otherwise normal. Similar opacities have been noted in association with other ocular and systemic diseases, such as pseudoxanthoma elasticum, X-linked ichthyosis, keratoconus, posterior polymorphous dystrophy, epithelial basement membrane dystrophy, and CCDF.

\section{Symptoms}

The vision is usually unaffected, and the patients are asymptomatic.

\section{Course}

Punctiform and polychromatic PDCD is nonprogressive. Other forms show progression.

\section{Light Microscopy}

Histopathologic studies are not consistent. Normal cornea except for enlarged keratocytes in the posterior stroma containing vacuoles and intracytoplasmic inclusions of lipidlike material.

\section{Transmission Electron Microscopy}

Membrane-bound intracellular vacuoles containing electron-dense material suggestive of secondary lysosomes and inclusions of a lipofuscin-like lipoprotein consistent with a degenerative process. No extracellular deposits noted.

\section{Confocal Microscopy}

Hyperreflective dots located anterior to Descemet membrane, and in 1 case reported to be present throughout the stroma.

\section{Category}

1. PDCD associated with X-linked ichthyosis.

4. Isolated PDCD

\section{BIBLIOGRAPHY}

- Costagliola C, Fabbrocini G, Illiano GM, et al. Ocular findings in X-linked ichthyosis: a survey on 38 cases. Ophthalmologica. 1991;202:152-155.

- Curran RE, Kenyon KR, Green WR. Pre-Descemet's membrane corneal dystrophy. Am J Ophthalmol. 1974;77:711-716

- Fernandez-Sasso D, Acosta JE, Malbran E. Punctiform and polychromatic pre-Descemet's dominant corneal dystrophy. Br J Ophthalmol. 1979;63:336-338.

- Grayson M, Wilbrandt M. Pre-Descemet dystrophy. Am J Ophthalmol. 1967;64:276-282.

- Hung C, Ayabe RI, Wang C, et al. Pre-Descemet corneal dystrophy and X-linked ichthyosis associated with deletion of Xp22.31 containing the STS gene. Cornea. 2013;32:1283-1287.

- Kempster, RC, Hirst, LW, de la Cruz Z, et al. Clinicopathologic study of the cornea in X-linked ichthyosis. Arch Ophthalmol. 1997;115:409-415.

- Lisch W, Weidle EG. Die posteriore kristalline Hornhautdystrophie. Klin Monatsbl Augenheilkd. 1984;185:128131.

- Ye YF, Yao YF, Zhou P, et al. In vivo confocal microscopy of pre-Descemet's membrane corneal dystrophy. Clin Experiment Ophthalmol. 2006;34:614-616. 
FIGURE 21. FECD. Cornea guttata in retroillumination $(A)$ and slit-lamp view (Ai). B and C, Epithelial edema and bullae, and stromal edema due to endothelial decompensation. D, Light microscopy: cornea guttata in the form of focal excrescences at the level of the endothelium; thickening of Descemet membrane (arrowhead); stromal and intraepithelial edema. PAS, bar $=200 \mu \mathrm{m}$. E, In vivo confocal microscopy shows polymegethism and pleomorphism of endothelial cells associated with round hyporeflective structures sometimes containing reflective material and corresponding to guttae $(400 \times 400 \mu \mathrm{m})$. Figures $21 \mathrm{~B}$ and $C$ from Figures $21 B$ and $D$ in Weiss JS, Møller HU, Lisch W, et al. The IC3D classification of the corneal dystrophies. Cornea. 2008;27(suppl 2):S1-S42.


\section{ENDOTHELIAL DYSTROPHIES}

\section{Fuchs Endothelial Corneal Dystrophy (FECD)}

MIM \#136800 (FECD1), MIM \#610158 (FECD2), MIM \#613267 (FECD3), MIM \#613268 (FECD4), MIM \#613269 (FECD5), MIM \#613270 (FECD6), MIM \#613271 (FECD7), MIM \#615523 (FECD8).

\section{Former Alternative Names and Eponyms}

Endoepithelial corneal dystrophy.

\section{Inheritance}

Cases without known inheritance are most common. Some cases with AD inheritance reported. Genetic basis of FECD is complex and heterogeneous, demonstrating variable expressivity and incomplete penetrance.

\section{Genetic Locus}

\section{Early-Onset FECD}

1p34.3-p32 (FECD1).

\section{Late-Onset FECD}

Association has been reported to 13pter-q12.13 (FECD2), 18q21.2-q21.3 (FECD3), 20p13-p12 (FECD4), 5q33.1-q35.2 (FECD5), 10p11.2 (FECD6), 9p24.1-p22.1 (FECD7), and $15 \mathrm{q} 25$ (FECD8).

\section{Gene}

Early-onset FECD: collagen, type VIII, alpha-2, COL8A2.

152 | www.corneajrnl.com

\section{Onset}

Most cases begin in the fourth decade or later, but the early variant starts in the first decade. Both early and later onset forms have female predominance at a ratio of 2.5:1 to 3:1.

\section{Signs}

Cornea guttata starts centrally and spreads peripherally (stage 1) (Fig. 21A). Some patients demonstrate guttae but never progress to later stages, whereas others advance to endothelial decompensation and stromal edema (stage 2). Corneal endothelium has a beaten metal-like appearance with or without pigment dusting. Corneal guttae in late-onset FECD are larger than those seen in early-onset FECD. Descemet membrane is thickened. Stromal edema may progress to involve the epithelium causing intraepithelial and interepithelial edema (epithelial bullae); bullous keratopathy (stage 3) (Figs. 21B, C). Subepithelial fibrosis, scarring, and peripheral superficial vascularization from chronic edema occur in long-standing cases (stage 4).

\section{Symptoms}

Intermittent reduced vision from epithelial/stromal edema. Visual acuity worse in the morning because of increased stromal/epithelial edema after overnight eye closure. Pain, photophobia, and epiphora due to epithelial erosions resulting from ruptured epithelial bullae. Progressive visual loss. Guttae alone may not cause corneal edema, and mild cornea edema may not result in decreased vision. More severe disease associated with decreased vision often has epithelial and stromal edema and fibrosis.

Copyright (C) 2014 Wolters Kluwer Health, Inc. All rights reserved. 


\section{Course}

Progressive.

\section{Light Microscopy}

Diffuse thickening and lamination of Descemet membrane. Sparse and atrophic endothelial cells, hyaline excrescences (guttae) on thickened Descemet membrane (Fig. 21D). Guttae become buried or confluent, or may be absent. Degeneration, thinning, and reduction of endothelial cells. Increasing waviness of the stromal collagen lamellae.

\section{Transmission Electron Microscopy}

\section{Early-onset FECD}

Thickened anterior banded layer of Descemet membrane. Degeneration of endothelial cells. Stromal thickening with severe disorganization and disruption of the lamellar pattern.

\section{Late-onset FECD}

Multiple layers of basement membrane-like material on the posterior nonbanded part of Descemet membrane.

\section{Confocal Microscopy}

Polymegethism, pleomorphism, decreased hexagonality, and reduced number of endothelial cells (Fig. 21E).

\section{Category}

1. early-onset FECD.

2. in patients with identified genetic loci.

3 . in patients without known inheritance.

\section{BIBLIOGRAPHY}

- Aldave AJ, Han J, Frausto RF. Genetics of the corneal endothelial dystrophies: an evidence based review. Clin Genet. 2013;84:109-119.

- Baratz KH, Tosakulwong N, Ryu E, et al. E2-2 protein and Fuchs's corneal dystrophia. N Engl J Med. 2010;363:10161024.

- Biswas S, Munier FL, Yardley J, et al. Missense mutations in COL8A2, the gene encoding the alpha2 chain of type VIII collagen, cause two forms of corneal endothelial dystrophy. Hum Mol Genet. 2001;10:2415-2423.

- Bucher F, Adler W, Lehmann HC, et al. Corneal nerve alterations in different stages of Fuchs' endothelial corneal dystrophy: an in vivo confocal microscopy study. Graefes Arch Clin Exp Ophthalmol. 2014;252:1119-1126.

- Fuchs E. Dystrophea epithelialis corneae. Arch Ophthalmol. 1910;76:478-508.

- Gottsch JD, Sundin OH, Liu SH, et al. Inheritance of a novel COL8A2 mutation defines a distinct early-onset subtype of Fuchs corneal dystrophy. Invest Ophthalmol Vis Sci. 2005;46:1934-1939.

- Hogan MJ, Wood J, Fine M. Fuchs'endothelial dystrophy of the cornea. Am J Ophthalmol. 1974;78:363-383.

- Krachmer JH, Purcell JJ Jr, Joung CW, et al. Corneal endothelial dystrophy. A study of 64 families. Arch Ophthalmol. 1978;96:2036-2039.
- Magovern M, Beauchamp GR, McTigue JW, et al. Inheritance of Fuchs' combined dystrophy. Ophthalmology. 1979;86:1897-1923.

- Mootha VV, Gong X, Ku HC, et al. Association and familial segregation of CTG18.1 trinucleotide repeat expansion of TCF4 gene in Fuchs' endothelial corneal dystrophy. Invest Ophthalmol Vis Sci. 2014;55:33-42.

- Riazuddin SA, Eghrari AO, Al-Saif A, et al. Linkage of a mild late-onset phenotype of Fuchs corneal dystrophy to a novel locus at 5q33.1-q35.2. Invest Ophthalmol Vis Sci. 2009;50:5667-5671.

- Riazuddin SA, Parker DS, McGlumphy EJ, et al. Mutations in LOXHD1, a recessive-deafness locus, cause dominant late-onset Fuchs corneal dystrophy. Am J Hum Genet. 2012;90:533-539.

- Riazuddin SA, Vasanth S, Katsanis N, et al. Mutations in AGBL1 cause dominant late-onset Fuchs corneal dystrophy and alter protein-protein interaction with TCF4. Am J Hum Genet. 2013;93:758-764.

- Riazuddin SA, Vithana EN, Seet LF, et al. Missense mutations in the sodium borate cotransporter SLC4A11 cause late-onset Fuchs corneal dystrophy. Hum Mutat. 2010;31:1261-1268.

- Riazuddin SA, Zaghloul NA, Al-Saif A, et al. Missense mutations in TCF8 cause late-onset Fuchs corneal dystrophy and interact with FCD4 on chromosome 9p. Am J Hum Genet. 2010;86:45-53.

- Sundin OH, Broman KW, Chang HH, et al. A common locus for late-onset Fuchs corneal dystrophy maps to 18q21.2q21.32. Invest Ophthalmol Vis Sci. 2006;47:3919-3926.

- Sundin OH, Jun AS, Broman KW, et al. Linkage of lateonset Fuchs corneal dystrophy to a novel locus at 13pTel13q12.13. Invest Ophthalmol Vis Sci. 2006;47:140-145.

- Vithana EN, Morgan PE, Ramprasad V, et al. SLC4A11 mutations in Fuchs endothelial corneal dystrophy. Hum Mol Genet. 2008;17:656-666.

- Wieben ED, Alaff RA, Tosakulwong N, et al. A common trinucleotide repeat expansion within the transcription factor 4 (TCF4, E2-2) gene predicts Fuchs corneal dystrophy. PLoS One. 2012;7:e49083.

- Zhang C, Bell WR, Sundin OH, et al. Immunohistochemistry and electron microscopy of early-onset Fuchs corneal dystrophy in three cases with the same L450W COL8A2 mutation. Trans Am Ophthalmol Soc. 2006;104:85-97.

\section{Posterior Polymorphous Corneal Dystrophy (PPCD)}

MIM \#122000 (PPCD1), MIM \#609140 (PPCD2), MIM \#609141 (PPCD3).

\section{Former Alternative Names and Eponyms}

Posterior polymorphous dystrophy.

Schlichting dystrophy.

\section{Inheritance}

Autosomal dominant. heredity.

Isolated unilateral cases, with similar phenotype but no www.corneajrnl.com | 153 

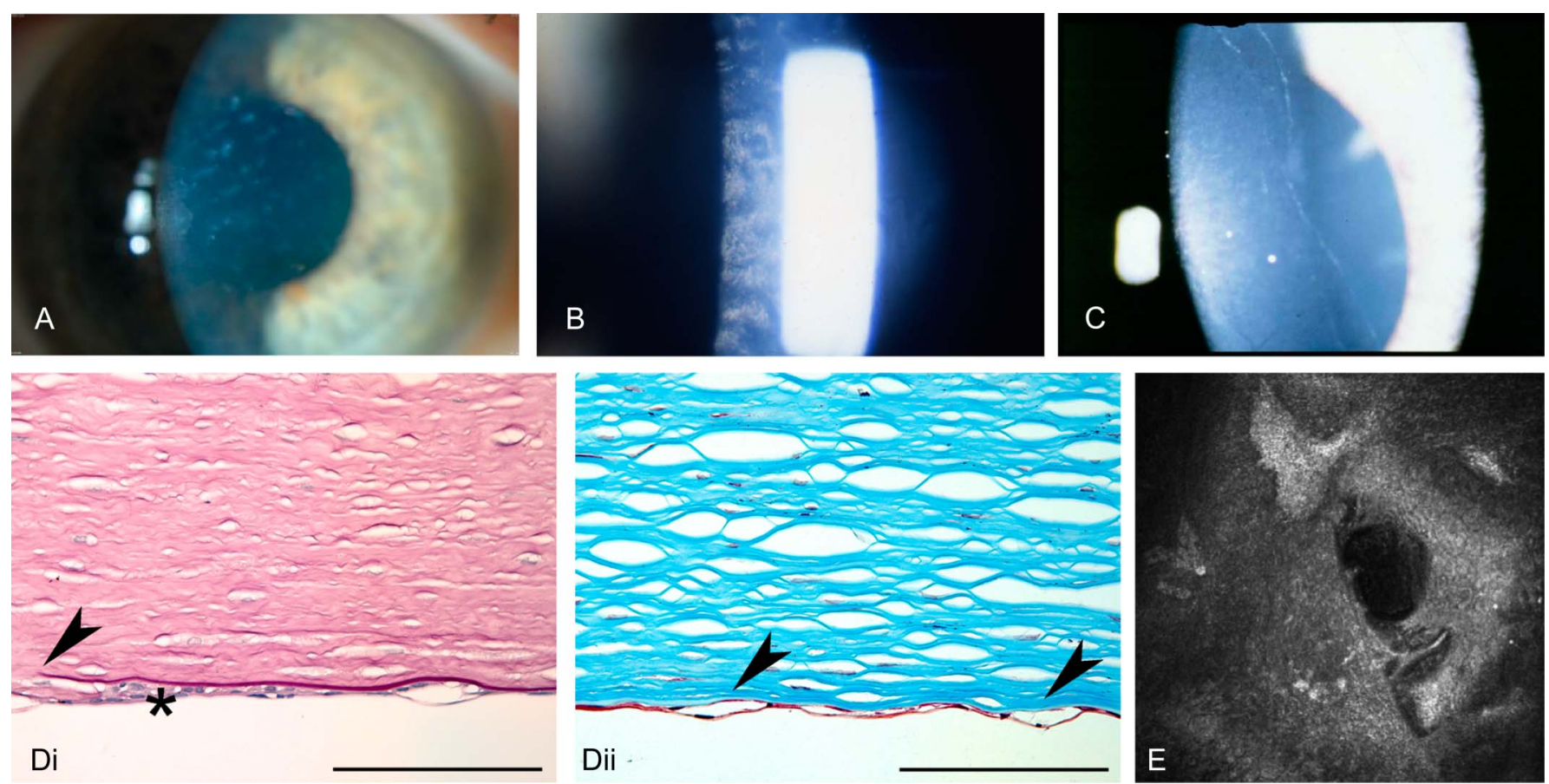

$\mathrm{Di}$

Dii

FIGURE 22. PPCD. A, Endothelial plaque-like lesions. B, Irregular crater-like figures on Descemet membrane viewed with specular reflection. C, Endothelial railroad track alteration. D, Light microscopy: PAS stain (i) and Masson trichrome (ii) show that the endothelium is replaced with flat epithelial-like cells that grow focally as more than 1 layer of cells (i; asterisk) and forms blisters (ii; arrowheads) and occasionally elevated strands. Posterior stroma may show pits or discontinuities in Descemet membrane (i; arrowhead), bar $=100 \mu \mathrm{m}$. E, In vivo confocal microscopy showing vesicular lesions and band-like structures with irregular edges within the endothelium associated with polymegethism of endothelial cells $(400 \times 400 \mu \mathrm{m})$. Figures $22 \mathrm{~A}$, B, and $\mathrm{C}$ from Figures 22A, B, and C in Weiss JS, Møller HU, Lisch W, et al. The IC3D classification of the corneal dystrophies. Cornea. 2008;27 (suppl 2):S1-S42.

\section{Genetic Locus}

PPCD 1: 20p11.2-q11.2.

PPCD 2: 1p34.3-p32.3.

PPCD 3: 10p11.22.

\section{Gene}

PPCD 1: unknown.

PPCD 2: collagen, type VIII, alpha-2 (COL8A2).

PPCD 3: zinc finger E box-binding homeobox 1 (ZEBI).

\section{Onset}

Early childhood.

\section{Signs}

Often asymmetric. Opacities of Descemet membrane and endothelium with characteristic morphologic features: geographic gray opacities; vesicular lesions, either single or grouped, often surrounded by gray circular opacity; parallel gray-white endothelial bands with white "flaky" material along the bands (railroad tracks), which may extend across the entire cornea (Figs. 22A-C). Occasional cases may be associated with diffuse opacification of Descemet membrane and multiple larger vesicular endothelial opacities. Both keratoconic and nonkeratoconic corneal steepening have been reported, with the majority of individuals with PPCD3 demonstrating corneal curvatures greater than 48.0 diopters in both eyes. Corneal edema may develop, necessitating corneal transplantation in approximately $20 \%$ to $25 \%$ of affected individuals. Peripheral iridocorneal adhesions in about $25 \%$ of cases and elevated intraocular pressure in about $15 \%$ of cases.

\section{Symptoms}

Endothelial alterations often asymptomatic. Visual impairment may develop secondary to corneal edema.

\section{Course}

Rarely congenital corneal clouding. Endothelial changes often unchanged over years. Possible slow progression of polymorphic vesicles and greater thickness of Descemet membrane over years and decades occasionally causing endothelial decompensation.

\section{Light Microscopy}

Descemet membrane with multiple layers of collagen on its posterior surface manifesting focal fusiform or nodular excrescences. Blebs, discontinuities, or reduplication of the endothelial cell layer (Fig. 22D).

\section{Transmission Electron Microscopy}

The anterior banded portion of Descemet membrane is normal, although the posterior nonbanded portion may be 
markedly abnormal, demonstrating alterations in thickness, a multilaminar appearance and occasional guttae. Two types of collagenous tissue posterior to Descemet membrane form layers up to $25 \mathrm{~nm}$ thick. Affected endothelial cells display ultrastructural characteristics of epithelial cells, such as microvilli and desmosomes.

\section{Immunohistochemistry}

PPCD 1: positive with anti-CK7, CK8, CK18, and CK19 antibodies.

\section{Confocal Microscopy}

Vesicular lesions: rounded dark areas with some cell detail apparent in the middle giving a doughnut-like appearance (Fig. 22E). Multilayered nests of cells. "Railroad-track": band-like dark area with irregular edges enclosing some smaller lighter epithelial-like cells. Polymegethism of the endothelium.

\section{Category \\ 1. PPCD 2 and PPCD 3 \\ 2. PPCD 1}

Note: Clinical, histopathologic, and electron microscopic descriptions of 2 of the 5 families reported with AD CHED (Kanai A, Kaufman HE. Invest Ophthalmol. 1971; Kanai A, Waltman S, Polack FM, et al. Invest Ophthalmol. 1971; and Levenson JE, Chandler JW, Kaufman HE. Am J Ophthalmol. 1973) are consistent with PPCD, although neither linkage to the PPCD1 locus nor ZEB1 screening has been performed in either family. Another of the 5 families (Pearce et al. $\mathrm{Br} J$ Ophthalmol. 1969; Kirkness, et al. Br J Ophthalmol. 1987; and Toma, et al. Hum Mol Genet. 1995) may have PPCD based on clinical, histopathologic, and electron microscopic analyses, although a higher percentage of affected individuals in this family demonstrate corneal edema, with an earlier onset and more significant edema compared with the majority of families with PPCD. Because linkage analysis in this family demonstrated linkage to the region of chromosome 20 that is common to 4 families with PPCD, it is probable that the family originally reported by Pearce et al also has PPCD1, with a more severe phenotype than that of other PPCD1 pedigrees. However, as it is possible that the corneal endothelial dystrophy in this family and PPCD1 are allelic variants, or are associated with mutations in 2 different genes in the common linked interval for these endothelial dystrophies, we support the use of the original name used by Pearce et al, congenital endothelial corneal dystrophy, to describe the condition in this family. Identification of the genetic basis of PPCD1 will allow definitive determination of whether PPCD1 and congenital endothelial corneal dystrophy are in fact the same.

\section{BIBLIOGRAPHY}

- Aldave AJ, Ann LB, Frausto RF, et al. Classification of posterior polymorphous corneal dystrophy as a corneal ectatic disorder following confirmation of associated significant corneal steepening. JAMA Ophthalmol. 2013;131:1583-1590.

Copyright (C) 2014 Wolters Kluwer Health, Inc. All rights reserved.
- Bakhtiari P, Frausto RF, Roldan AN, et al. Exclusion of pathogenic promoter region variants and identification of novel nonsense mutations in the zinc finger E-box binding homeobox 1 gene in posterior polymorphous corneal dystrophy. Mol Vis. 2013;19:575-580.

- Cibis GW, Krachmer JA, Phelps CD, et al. The clinical spectrum of posterior polymorphous dystrophy. Arch Ophthalmol. 1977;95:1529-1537.

- Héon E, Mathers WD, Alward WL, et al. Linkage of posterior polymorphous corneal dystrophy to 20q11. Hum Mol Genet. 1995;4:485-488.

- Kanai A, Kaufman HE. Further electron microscopic study of hereditary corneal edema. Invest Ophthalmol. 1971;10:545-554.

- Kanai A, Waltman S, Polack FM, et al. Electron microscopic study of hereditary corneal edema. Invest Ophthalmol. 1971;10:89-99.

- Kirkness CM, McCartney A, Rice NS, et al. Congenital hereditary corneal oedema of Maumenee: its clinical features, management, and pathology. $\mathrm{Br} J$ Ophthalmol. 1987;71:130-144.

- Koeppe L. Klinische Beobachtungen mit der Nernstspaltlampe und dem Hornhautmikroskop. Albrecht von Graefes Arch Klin Exp Ophthalmol. 1916;91:363-379.

- Krafchak CM, Pawar H, Moroi SE, et al. Mutations in TCF8 cause posterior polymorphous corneal dystrophy and ectopic expression of COL4A3 by corneal endothelial cells. Am J Hum Genet. 2005;77:694-708.

- Levenson JE, Chandler JW, Kaufman HE. Affected asymptomatic relatives in congenital hereditary endothelial dystrophy. Am J Ophthalmol. 1973;76:967-971.

- Patel DV, Grupcheva CN, McGhee CNJ. In vivo microscopy of posterior polymorphous dystrophy. Cornea. 2005;24:550-554.

- Pearce WG, Tripathi RC, Morgan G. Congenital endothelial corneal dystrophy. Clinical, pathological, and genetic study. Br J Ophthalmol. 1969;53:577-591.

- Rodrigues MM, Waring GO, Laibson PR, et al. Endothelial alterations in congenital corneal dystrophies. Am J Ophthalmol. 1975;80:678-689.

- Schlichting H. Blasen-und dellenförmige Endotheldystrophie der Hornhaut. Klin Monatsbl Augenkeilkd. 1941;107:425-435.

- Shimizu S, Krafchak C, Fuse N, et al. A locus for posterior polymorphous corneal dystrophy (PPCD3) maps to chromosome 10. Am J Med Genet. 2004;130:372-377.

- Toma NM, Ebenezer ND, Inglehearn CF, et al. Linkage of congenital hereditary endothelial dystrophy to chromosome 20. Hum Mol Genet. 1995;4:2395-2398.

- Yellore VS, Rayner SA, Emmert-Buck L, et al. No pathogenic mutations identified in the COL8A2 gene or four positional candidate genes in patients with posterior polymorphous corneal dystrophy. Invest Ophthalmol Vis Sci. 2005;46:1599-1603.

\section{Congenital Hereditary Endothelial Dystrophy (CHED)}

MIM \#217700.

Note: To date there is no convincing published evidence to support the existence of AD CHED as a distinct 



FIGURE 23. CHED. A and B, Right and left corneas of a 30-year-old woman with CHED. Screening of SLC4A11 demonstrated a homozygous (Thr271Met) mutation. Photograph courtesy of Dr Majid Moshirfar. C, Slit-beam photograph demonstrating diffuse stromal thickening in an individual with SLC4A11 mutations. D, Light microscopy: edema of basal epithelial cells with subepithelial lacunae (open arrowhead) and breaks (arrowhead) in the Bowman layer, bar $=80 \mu \mathrm{m}$. E, Thickened Descemet membrane with no visible endothelial cells, bar $=50 \mu \mathrm{m}$. Figure 23C from Figure 23B in Weiss JS, Møller HU, Lisch W, et al. The IC3D classification of the corneal dystrophies. Cornea. 2008;27(suppl 2):S1-S42.

entity. Therefore, we have removed AD CHED, formerly known as CHED1, from our classification system, so that AR CHED formerly known as CHED2 will be renamed CHED.

\section{Former Alternative Names and Eponyms}

Maumenee corneal dystrophy.

\section{Inheritance}

Autosomal recessive.

\section{Genetic Locus}

$20 \mathrm{p} 13$.

\section{Gene}

Solute carrier family 4, sodium borate transporter, member $11-(S L C 4 A 11)$ gene mutations identified in $76 \%$ of CHED pedigrees screened in 1 publication.

\section{Onset}

Congenital.

\section{Signs}

Bilateral. Often asymmetric. Corneal clouding ranging from diffuse haze to ground-glass milky appearance with occasional focal gray spots (Figs. 23A, B). Thickening of the cornea (can be 2-3 times the normal thickness) (Fig. 23C). Rarely secondary subepithelial band keratopathy. Rarely elevated intraocular pressure. Endothelial cell count reduced significantly (about 10-fold as compared with age-matched controls).

\section{Symptoms}

Corneal clouding with blurred vision often accompanied by nystagmus. Minimal to no tearing or photophobia.

\section{Course}

Relatively stationary with little or no progression.

\section{Light Microscopy}

Diffuse epithelial and stromal edema (Fig. 23D), defects in the Bowman layer, degenerated corneal endothelium with multinucleated sparse and atrophic endothelial cells, and a thickened laminated Descemet membrane (Fig. 23E) due to abnormal and accelerated secretion by the endothelial cells.

\section{Transmission Electron Microscopy}

Multiple layers of basement membrane-like material on the posterior part of Descemet membrane. Degeneration of endothelial cells with many vacuoles. Stromal thickening with severe disorganization and disruption of the lamellar pattern.

\section{Immunohistochemistry}

Collagen types I, III and V within the posterior collagenous layer of Descemet membrane from fibroblastlike change of the endothelial cells. 


\section{Confocal Microscopy}

Not reported.

\section{Category \\ 1. \\ 3 for patients without SLC4A11 mutations.}

Note: Mutations in SLC4A11 are also responsible for Harboyan syndrome, a disorder involving congenital corneal endothelial dystrophy and progressive postlingual sensorineural hearing loss.

\section{BIBLIOGRAPHY}

- Aldahmesh MA, Khan AO, Meyer BF, et al. Mutational spectrum of SLC4A11 in autosomal recessive CHED in Saudi Arabia. Invest Ophthalmol Vis Sci. 2009;50:41424145.

- Aldave AJ, Han J, Frausto RF. Genetics of the corneal endothelial dystrophies: an evidence based review. Clin Genet. 2013;84:109-119.

- Aldave AJ, Yellore VS, Bourla N, et al. Autosomal recessive CHED associated with novel compound heterozygous mutations in SLC4A11. Cornea. 2007;26:896-900.

- Callaghan M, Hand CK, Kennedy SM, et al. Homozygosity mapping and linkage analysis demonstrate that autosomal recessive congenital hereditary endothelial dystrophy (CHED) and autosomal dominant CHED are genetically distinct. Br J Ophthalmol. 1999;83:115-119.
- Desir J, Abramowicz M. Congenital hereditary endothelial dystrophy with progressive sensorineural deafness (Harboyan syndrome). Orphanet $J$ Rare Dis. 2008;3:28. doi: 10.1186/1750-1172-3-28.

- Desir J, Moya G, Reish O, et al. Borate transporter SLC4A11 mutations cause both Harboyan syndrome and non-syndromic corneal endothelial dystrophy. $J$ Med Genet. 2007;44:322-326.

- Ehlers N, Modis L, Moller-Pedersen T. A morphological and functional study of congenital hereditary endothelial dystrophy. Acta Ophthalmol Scand. 1998;76:314-318.

- Jalimarada SS, Ogando DG, Vithana EN, et al. Ion transport function of SLC4A11 in corneal endothelium. Invest Ophthalmol Vis Sci. 2013;54:4330-4340.

- Jiao X, Sultana A, Garg P, et al. Autosomal recessive corneal endothelial dystrophy (CHED2) is associated with mutations in SLC4A11. J Med Genet. 2007;44:64-68.

- Kenyon KR, Antine B. The pathogenesis of congenital hereditary endothelial dystrophy of the cornea. $\mathrm{Am} \mathrm{J}$ Ophthalmol. 1971;72:787-795.

- Kim JH, Ko JM, Tchah H. Fuchs endothelial corneal dystrophy in a heterozygous carrier of congenital hereditary endothelial dystrophy type 2 with a novel mutation in SLC4A11. Ophthalmic Genet. 2014. [Epub ahead of print].

- Kirkness CM, McCartney A, Rice NS, et al. Congenital hereditary corneal edema of Maumenee: its clinical features, management, and pathology. $\mathrm{Br} J$ Ophthalmol. 1987;71:130-144.
FIGURE 24. X-linked endothelial corneal dystrophy. A, Male infant with congenital corneal haze. B, The mother of the infant with moon craterlike endothelial changes in retroillumination. C, Light microscopy: scarce endothelial cells (arrowheads) with atypical appearance, bar $=100$ $\mu \mathrm{m}$. D, Electron microscopy: degenerative endothelial cell adjacent to denuded area (arrow) of Descemet membrane (DN), $\times 10,000$. $N$, nucleus.
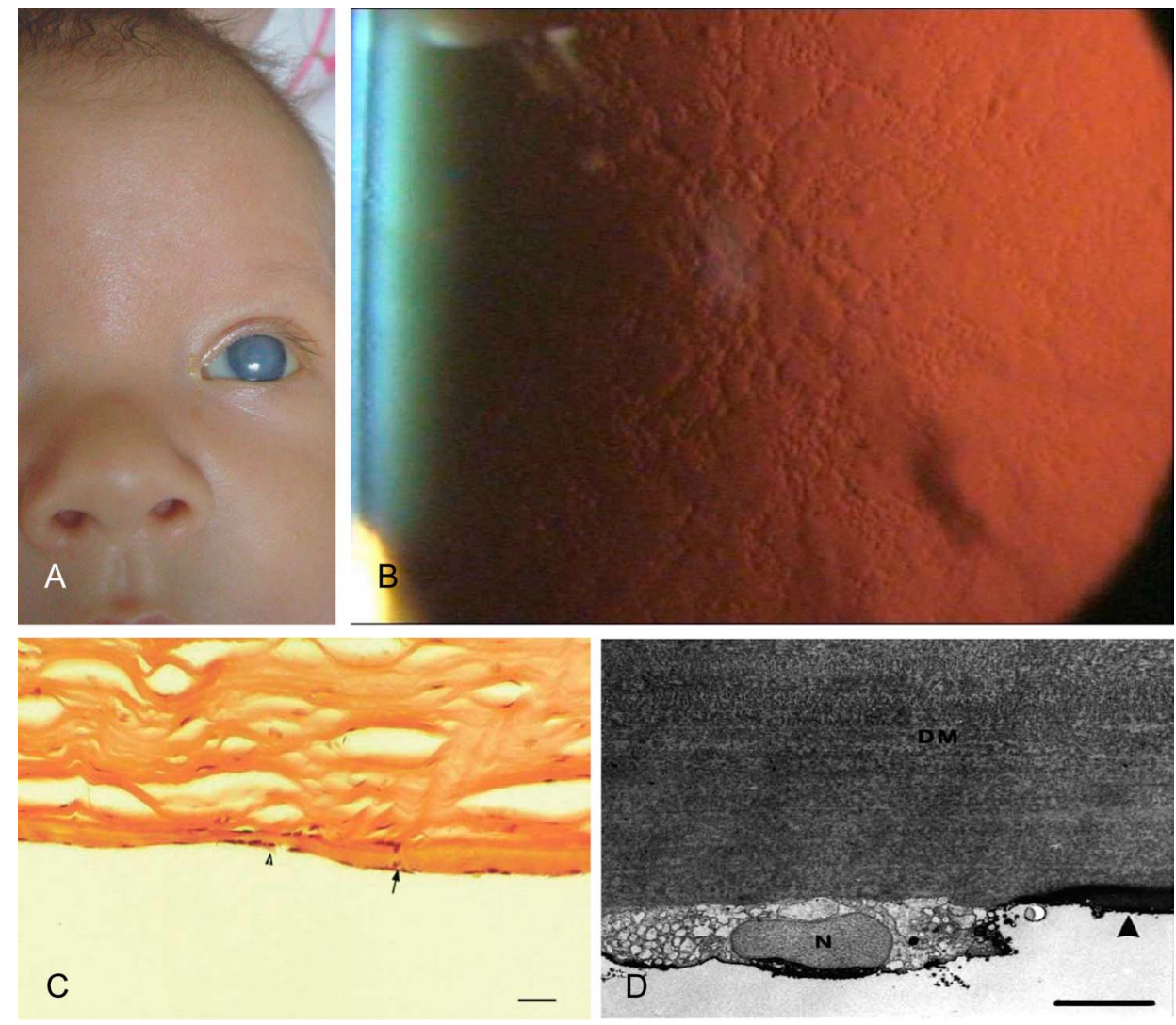
- Loganathan SK, Casey JR. Corneal dystrophy-causing SLC4A11 mutants: suitability for folding-correction therapy. Hum Mutat. 2014;35:1082-1091.

- Maumenee AE. Congenital hereditary corneal dystrophy. Am J Ophthalmol. 1960;50:1114-1124.

- Mittal V, Mittal R. Challenges in pediatric endothelial keratoplasty. Indian J Ophthalmol. 2014;62:251-254.

- Sekundo W, Marshall GE, Lee WR, et al. Immuno-electron labeling of matrix components in congenital hereditary endothelial dystrophy. Graefes Arch Clin Exp Ophthalmol. 1994;232:337-346.

- Shah SS, Al-Rajhi A, Brandt JD, et al. Mutation in the SLC4A11 gene associated with autosomal recessive congenital hereditary endothelial dystrophy in a large Saudi family. Ophthalmic Genet. 2008;29:41-45.

- Siddiqui S, Zenteno JC, Rice A, et al. Congenital hereditary endothelial dystrophy caused by SLC4A11 mutations progresses to Harboyan syndrome. Cornea. 2014;33:247-251.

- Sultana A, Garg P, Ramamurthy B, et al. Mutational spectrum of the SLC4A11 gene in autosomal recessive congenital hereditary endothelial dystrophy. Mol Vis. 2007;13:13271332.

- Vithana EN, Morgan P, Sundaresan P, et al. Mutations in sodium-borate cotransporter SLC4A11 cause recessive congenital hereditary endothelial dystrophy (CHED 2). Nat Genet. 2006;38:755-757.

\section{X-linked Endothelial Corneal Dystrophy (XECD)}

MIM: none.

\section{Former Alternative Names and Eponyms}

None.

\section{Inheritance}

$\mathrm{X}$-chromosomal dominant.

\section{Genetic Locus}

$\mathrm{Xq} 25$.

\section{Gene}

Unknown.

\section{Onset}

Congenital.

Signs

Males

Congenital clouding ranging from diffuse haze to ground-glass, milky appearance (Fig. 24A). Possible nystagmus.

Only moon crater-like endothelial changes.

Secondary subepithelial band keratopathy combined with moon crater-like endothelial changes.

\section{Females}

Only moon crater-like endothelial changes (Fig. 24B).

158 | www.corneajrnl.com

\section{Symptoms}

Males

Often blurred vision.

\section{Females}

Asymptomatic.

\section{Course}

Males

Minimally progressive.

\section{Females}

Nonprogressive.

\section{Light Microscopy}

Moon crater-like endothelial changes and subepithelial keratopathy. Irregular thinning of the epithelium and Bowman layer. Anterior stroma with irregularly arranged collagen lamellae. Irregular thickening of Descemet membrane with small excavations and pits. Loss of endothelial cells or atypical appearance (Fig. 24C).

\section{Transmission Electron Microscopy}

Moon crater-like endothelial changes and subepithelial band keratopathy. Subepithelial accumulations of an amorphous granular material. Irregular thinning of the Bowman layer (up to $0.5 \mu \mathrm{m}$ ) with many interruptions and gaps. Thickening of Descemet membrane $(20-35 \mu \mathrm{m})$ consisting of an abnormal anterior and posterior banded zone. Complete absence of the posterior nonbanded zone. Discontinuous endothelial layer with partly normal and partly degenerative appearing cells (Fig. 24D). No evidence of desmosome-like adherent junctions between the cells or tonofilament bundles within the cytoplasm.

\section{Confocal Microscopy}

Not reported.

\section{Category}

2 .

\section{BIBLIOGRAPHY}

- Lisch W. Primaere bandfoermige Hornhautdegeneration und ihre Assoziation mit anderen erblichen Hornhautveraenderungen. Klin Monatsbl Augenheilkd. 1976;169:717727.

- Schmid E, Lisch W, Philipp W, et al. A new, X-linked endothelial corneal dystrophy. Am $J$ Ophthalmol. 2006;141:478-487.

\section{ACKNOWLEDGMENTS}

The authors thank The Cornea Society, Research to Prevent Blindness, and the Louisiana Lions Eye Foundation

Copyright $(02014$ Wolters Kluwer Health, Inc. All rights reserved. 
for their generous support. Editorial assistance by Nicole Dicks and Alana Weiss Nydorf is appreciated by the IC 3D.

\section{REFERENCES}

1. Weiss JS, Møller HU, Lisch W, et al. The IC3D classification of the corneal dystrophies [in English and Spanish]. Cornea. 2008;27(suppl 2): S1-S83.

2. Groenouw A. Knoetchenfoermige Hornhauttruebungen (Noduli corneae). Arch Augenheilkd. 1890;21:281-289.

3. Biber H. Ueber einige seltene Hornhauterkrankungen: die oberflaechliche gittrige Keratitis [Inaugural Dissertation]. A Diggelmann Zuerich. 1890.

4. Fuchs E. Dystrophia epithelialis corneae. Arch Ophthalmol. 1910;76: 478-508.

5. Uthoff W. Ein Fall von doppelseitiger zentraler, punktfoermiger, supepithelialer knoetchenfoermiger Keratitis, Groenouw mit anatomischem Befunde. Klin Monatsbl Augenheilkd. 1915;54:377-383.

6. Yoshida Y. Ueber eine neue Art der Dystrophia corneae mit histologischem Befunde. Albrecht von Graefes Arch Clin Exp Ophthalmol. 1924; 114:91-100.

7. Afshari NA, Bouchard CS, Colby KA, de Freitas D, Rootman DS, $\mathrm{Tu}$ EY, Weisenthal RW. Corneal dystrophies and ectasias. In: Weisenthal RW, ed. 2014-2015 Basic and Clinical Science Course, Section 8: External Disease and Cornea. San Francisco; American Academy of Ophthalmology; 2014:253-287.

8. Aldave AJ, Yellore VS, Salem AK, et al. No VSX1 gene mutations associated with keratoconus. Invest Ophthalmol Vis Sci. 2006;47:2820-2822.

9. Dash DP, George S, O'Prey D, et al. Mutational screening of VSX1 in keratoconus patients from the European population. Eye (Lond). 2010; 24:1085-1092.

10. Edwards M, McGhee CN, Dean S. The genetics of keratoconus. Clin Experiment Ophthalmol. 2001;29:345-351.

11. Rabinowitz YS. The genetics of keratoconus. Ophthalmol Clin North Am. 2003;16:607-620.

12. Tyynismaa H, Sistonen $\mathrm{P}$, Tuupanen $\mathrm{S}$, et al. A locus for autosomal dominant keratoconus: linkage to 16q22.3-q23.1 in Finnish families. Invest Ophthalmol Vis Sci. 2002;43:3160-3164.

13. Wang Y, Rabinowitz YS, Rotter JI, et al. Genetic epidemiological study of keratoconus: evidence for major gene determination. Am J Med Genet. 2000;93:403-409.

14. Waring GO III, Rodrigues MM, Laibson PR. Corneal dystrophies. I. Dystrophies of the epithelium, Bowman's layer and stroma. Surv Ophthalmol. 1978;23:71-122.

15. Waring GO III, Rodrigues MM, Laibson PR. Corneal dystrophies. II. Endothelial dystrophies. Surv Ophthalmol. 1978;23:147-168.

16. François J. Une nouvelle dystrophie hérédo-familiale de la cornée. J Genet Hum. 1956;5:189-196.

17. Strachan IM. Cloudy central corneal dystrophy of François. Five cases in the same family. Br J Ophthalmol. 1969;53:192-194

18. Bramsen T, Ehlers N, Baggesen LH. Central cloudy corneal dystrophy of François. Acta Ophthalmol (Copenh). 1976;54:221-226.

19. Karp CL, Scott IU, Green WR, et al. Central cloudy corneal dystrophy of François. A clinicopathologic study. Arch Ophthalmol. 1997;115: $1058-1062$.

20. Krachmer JH, Purcell JJ Jr, Young CW, et al. Corneal endothelial dystrophy. A study of 64 families. Arch Ophthalmol. 1978;96:2036-2039.

21. Hamill CE, Schmedt T, Jurkunas U. Fuchs endothelial cornea dystrophy: a review of the genetics behind disease development. Semin Ophthalmol. 2013;28:281-286.

22. Weiss JS. Schnyder's dystrophy of the cornea. A Swede-Finn connection. Cornea. 1992;11:93-101.

23. Weiss JS. Schnyder crystalline dystrophy sine crystals. Recommendation for a revision of nomenclature. Ophthalmology. 1996;103:465-473.
24. Weiss JS. Visual morbidity in 34 families with Schnyder's crystalline corneal dystrophy. A clinical pathologic report with quantitative analysis of corneal lipid composition. Ophthalmology. 1994;101:895-901.

25. Aldave AJ, Edward DP, Park AJ, et al. Central discoid corneal dystrophy. Cornea. 2002;21:739-744.

26. Weiss JS, Wiaux C, Yellore V, et al. Reported p.Asp240Asn mutation in UBIAD1 suggests central discoid corneal dystrophy is a variant of Schnyder corneal dystrophy. Cornea. 2010;29:777-780.

27. Orr A, Dubé MP, Marcadier J, et al. Mutations in the UBIAD1 gene, encoding a potential prenyltransferase, are causal for Schnyder crystalline corneal dystrophy. PLoS One. 2007;2:e685.

28. Weiss JS, Kruth HS, Kuivaniemi H, et al. Mutations in the UBIAD1 gene on chromosome short arm 1, region 36 cause Schnyder crystalline corneal dystrophy. Invest Ophthalmol Vis Sci. 2007;48: 5007-5012

29. Grayson M, Wilbrandt $H$. Dystrophy of the anterior limiting membrane of the cornea (Reis-Bueckler type). Am J Ophthalmol. 1966;61:345-349.

30. Bouchard CS, Coroneo MT, Florakis GJ, et al. Corneal dystrophies and ectasias. In: Reidy JJ, ed. 2010-2011 Basic and Clinical Science Course, Section 8: External Disease and Cornea. San Francisco, CA: American Academy of Ophthalmology; 2010:267-303.

31. Kanai A, Waltman S, Polack FM, et al. Electron microscopic study of hereditary corneal edema. Invest Ophthalmol. 1971;10:89-99.

32. Kanai A, Kaufman HE. Further electron microscopy study of hereditary corneal edema. Invest Ophthalmol. 1971;10:545-554.

33. Levenson JE, Chandler JW, Kaufman HE. Affected asymptomatic relatives in congenital hereditary endothelial dystrophy. Am J Ophthalmol. 1973;76:967-971.

34. Aldave AJ, Han J, Frausto RF. Genetics of the corneal endothelial dystrophies: an evidence-based review. Clin Genet. 2013;84 109-119.

35. Yee RW, Sullivan LS, Lai HT, et al. Linkage mapping of Thiel-Behnke corneal dystrophy (CDB2) to chromosome 10q23-q24. Genomics. 1997; 46:152-154

36. Lohse E, Stock LE, Jones JC, et al. Reis-Büecklers' corneal dystrophy. Immunofluorescent and electron microscopic studies. Cornea. 1989;8: 200-209.

37. Nakamura H, Li FT, Folterman MO, et al. Individual phenotypic variances in a family with Thiel-Behnke corneal dystrophy. Cornea. 2012;31:1217-1222.

38. Lisch W, Kivelä T. Individual phenotypic variances in a family with Thiel-Behnke corneal dystrophy. Cornea. 2013;32:e192-e193.

39. Franceschetti A. Hereditaere rezidivierende Erosion der Hornhaut Z Augenheilk. 1928;66:309-316.

40. Hammar B, Bjöerck E, Lagerstedt K, et al. A new corneal disease with recurrent erosive episodes and autosomal-dominant inheritance. Acto Ophthalmol. 2008;86:758-763.

41. Lisch W, Bron AJ, Munier FL, et al. Franceschetti hereditary recurrent corneal erosion. Am J Ophthalmol. 2012;153:1073-1081.e4.

42. Hammar B, Bjöerck E, Lind H, et al. Dystrophia Helsinglandica: a new type of hereditary corneal recurrent erosions with late subepithelial fibrosis. Acta Ophthalmol. 2009;87:659-665.

43. Møller HU. "Corneal dystrophies". In: Hoyt C, Taylor D, eds. Paediatric Ophthalmology and Strabismus. 4th ed. Elsevier Science; 2012:323-328.

44. Hu M, Kestelyn P, Weiss JS. Pediatric corneal dystrophies. A plea for pictures. Cornea. 2010;29:1469.

45. Lisch W, Saikia P, Pitz S, et al. Chameleon-like appearance of immunotactoid keratopathy. Cornea. 2012;31:55-58.

46. Goetz KE, Reeves MJ, Tumminia SJ, et al. eyeGENE ${ }^{\circledR}$ : a novel approach to combine clinical testing and researching genetic ocular disease. Curr Opin Ophthalmol. 2012;23:355-363. 